\title{
Geomorphology and Quaternary Geology of the Glaciated Ohio River Valley- A Reconnaissance Study
}

GEOLOGICAL SURVEY PROFESSIONAL PAPER 826 



\section{Geomorphology and Quaternary Geology of the Glaciated Ohio River Valley- A Reconnaissance Study}

By LOUIS L. RAY

GEOLOGICAL SURVEY PROFESSIONAL PAPER 826

A study of the geomorphic development and drainage modifications resulting from the Quaternary glaciations of the Ohio River valley, from above Cincinnati, Ohio, to Louisville, Ky.

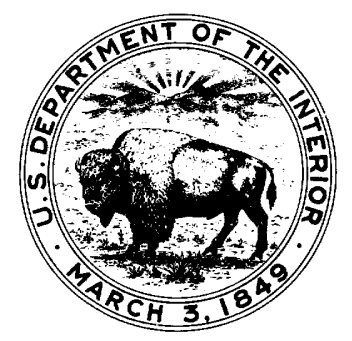

UNITED STATES GOVERNMENT PRINTING OFFICE, WASHINGTON : 1974 


\title{
UNITED STATES DEPARTMENT OF THE INTERIOR
}

ROGERS C. B. MORTON, Secretary

\section{GEOLOGICAL SURVEY}

\author{
V. E. McKelvey, Director
}

Library of Congress catalog-card No. 74-600081

For sale by the Superintendent of Documents, U.S. Government Printing Office Washington, D.C. 20402 - Price $\$ 2.65 \quad$ (paper cover)

Stock Number 2401-02556 


\section{CONTENTS}

Abstract

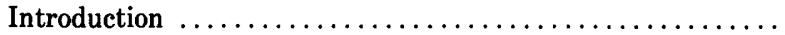

Regional setting ...

Pre-Quaternary geology $\ldots \ldots \ldots \ldots \ldots \ldots \ldots \ldots \ldots \ldots \ldots$

Bedrock formations and structure $\ldots \ldots \ldots \ldots \ldots \ldots$

Physiographic description ........................

Pre-Quaternary geomorphic and drainage development ..

Quaternary history of the Glaciated Ohio River valley ......

Nebraskan Glaciation

Drainage modifications resulting from the Nebraskan

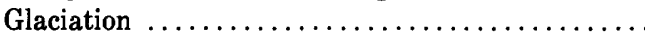

Drainage modifications above the Manchester divide

Drainage development between the Manchester divide

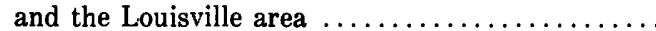

Aftonian interglacial time $\ldots \ldots \ldots \ldots \ldots \ldots \ldots \ldots \ldots \ldots$

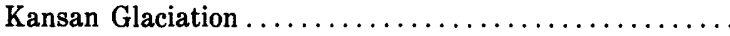

Drainage modifications resulting from the Kansan

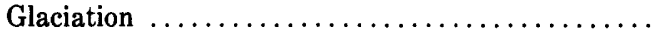

Yarmouth interglacial time.

\begin{tabular}{r}
\hline Page \\
1 \\
2 \\
4 \\
7 \\
7 \\
7 \\
11 \\
21 \\
22 \\
\\
29 \\
30 \\
\\
31 \\
33 \\
34 \\
39 \\
40
\end{tabular}

Quaternary history of the Glaciated Ohio River valley-Con

Illinoian Glaciation .......................... Drainage modifications resulting from the Illinoian

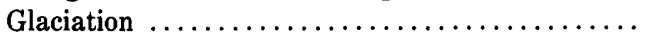

Sangamon interglacial time $\ldots \ldots \ldots \ldots \ldots \ldots \ldots \ldots$

Wisconsin Glaciation..$\ldots \ldots \ldots \ldots \ldots \ldots \ldots \ldots \ldots$

Valley trains and terraces resulting from the Wisconsin Glaciation ........................

The terrace of Tazewell age ................ Lacustrine deposits and terrace remnants of Tazewell age in valleys tributary to the sluiceways of Wisconsin age $\ldots \ldots \ldots \ldots \ldots$.

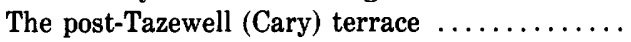

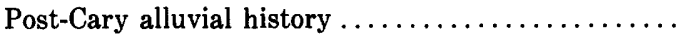

Flood plain of the Glaciated Ohio River valley ..........

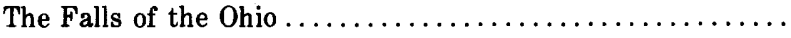

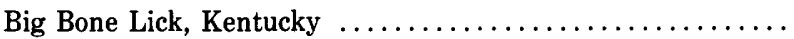

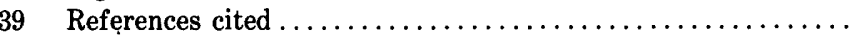

Index
Page

42

51

56

58

58

58

61

64

65

65

69

70

71

75

\section{ILLUSTRATIONS}

Plate

FIGURE
1. Generalized sketch map of glacial deposits in the Ohio River valley area

2. Topographic maps of the Ohio River valley, Indiana and Kentucky ...

1. Map of geomorphic subdivisions of the Ohio River valley ....

2. Index to U.S. Geological Survey topographic quadrangle maps of the Ohio River valley

3. Map of drainage basins directly tributary to the Glaciated Ohio River valley region $\ldots \ldots \ldots \ldots \ldots \ldots \ldots \ldots$

4. Generalized geologic map of the Bluegrass region and adjacent areas in Indiana, Kentucky, and Ohio ..........

5. Map of preglacial drainage basin of the upper Teays River

6-10. Sketch maps:

6. Major preglacial drainage channels in the vicinity of Cincinnati, Ohio $\ldots \ldots \ldots \ldots \ldots \ldots \ldots \ldots \ldots$

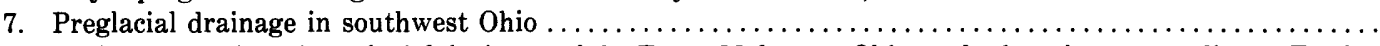

8. An interpretation of preglacial drainage of the Teays-Mahomet, Ohio, and other rivers according to Fowke, Malott, Wayne, and others

9. An interpretation of preglacial drainage of the Teays-Mahomet, Ohio, and other rivers according to

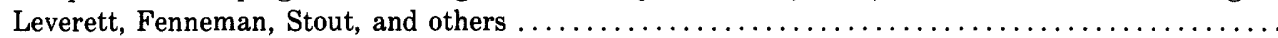

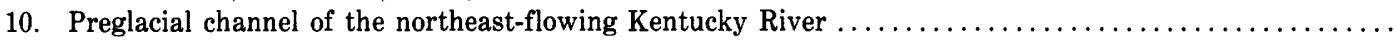

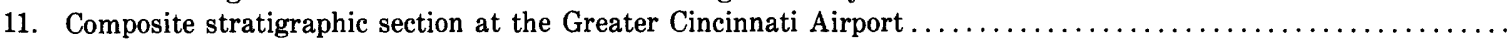

12-15. Topographic maps showing glacial drift of Illinoian age:

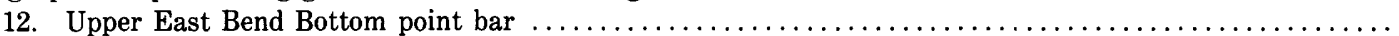

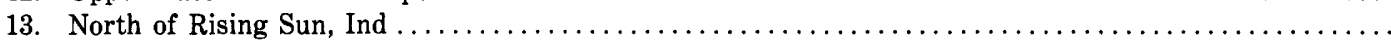

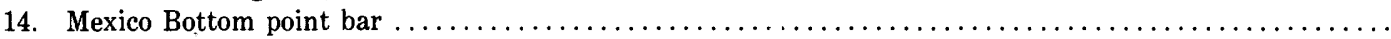

15. Egypt Bottom point bar

16. Sketch map of main drainage channels of the Cincinnati region immediately before Illinoian time $\ldots \ldots \ldots \ldots$.

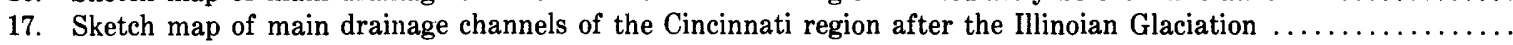

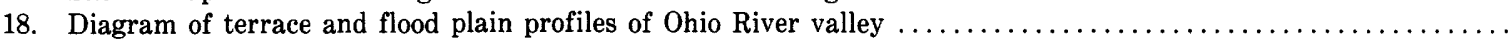

19. Remnants of dissected terrace in lower Gunpowder Creek valley $\ldots \ldots \ldots \ldots \ldots \ldots \ldots \ldots \ldots \ldots \ldots \ldots \ldots$

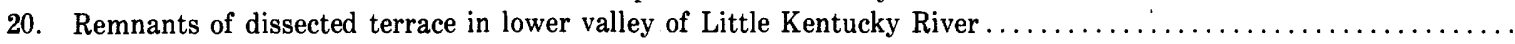

21. Lower Great Miami River valley in 1951

22. Lower Great Miami River valley in 1961
Page pocket pocket

3

5 


\section{TABLE}




\title{
GEOMORPHOLOGY AND QUATERNARY GEOLOGY OF THE GLACIATED OHIO RIVER VALLEY -A RECONNAISSANCE STUDY
}

\author{
By LouIs L. RAY
}

\section{ABSTRACT}

The Glaciated Ohio River valley extends from above Cincinnati, Ohio, to Louisville, $\mathrm{Ky}$. In this sector of the river valley, continuous deposits of glacial drift are present on both sides of the valley, indicating that at least one of the glaciations of Quaternary time crossed the site of the present river.

In pre-Quaternary time, the drainage pattern along the Glaciated Ohio River valley was wholly unlike that of today. Orientation of streams was largely dependent on bedrock lithology and structure, which in the Bluegrass region were dominated by the Cincinnati arch and by the subsidiary Jessamine dome, superimposed on the crest of the arch. Drainage from the Bluegrass region was to the north, between the divides produced by cuestalike outcrops of the dipping, erosion-resistant Silurian formations along the east and west flanks of the Cincinnati arch. These formations are readily recognizable as divides along the present Glaciated Ohio River valley at Manchester, Ohio, and at Madison, Ind. To the north, along the gently plunging crest of the Cincinnati arch, the Silurian formations dip so slightly that they crop out in a broad belt and show no well-defined escarpments; thus, no barrier was formed between the north-flowing streams from the Bluegrass region and the great Teays-Mahomet River, to which they were tributary.

Drainage from the Bluegrass region between the flanking escarpments of the Silurian formations was by three streams-the Manchester River from the east, the Licking River from the south, and the Kentucky River from the west. These streams converged near Hamilton, Ohio, and continued north as an important tributary to the Teays-Mahomet River.

West of the north-south Silurian escarpment and divide that crossed the present Ohio River valley at Madison, Ind., preglacial drainage was to the west along the course of a small northern branch of the Salt River of Kentucky. This minor stream, flowing independently to the Mississippi embayment, was later to become integrated into the stream that is today the main stem of the Ohio River. For this reason, the preglacial Ohio River is said to have had its headwaters on the back slope of the prominent Silurian cuesta, the so-called Laughery escarpment, at Madison, Ind.

In the Glaciated Ohio River valley region, the four major glaciations of Quaternary time caused drastic and highly complex modifications of the regional drainage system and the integration of the several drainage basins into a single basin, that of the present Ohio River. Each glaciation played a distinct and definite role in these complex drainage changes.

Perhaps the greatest and most drastic drainage changes were those produced by the invasion of the first ice sheet, the Nebraskan, the most widespread of all the Quaternary ice sheets in this area. This, the first great derangement of drainage, obliterated the Teays-Mahomet. River in Ohio, integrated the drainage above the divide at Manchester, and forced the impounded waters of the ice-dammed streams across both the Manchester and the Madison divides. Northward drainage from the Bluegrass region was largely blocked, and a great icemarginal stream, the early Ohio River, was produced.

When the Nebraskan ice sheet had disappeared from the Glaciated Ohio River valley, the newly integrated Ohio River is believed to have followed once again the preglacial channel of the Manchester River from the Manchester divide to the vicinity of Hamilton, Ohio, where, after joining the Licking River, it followed the sinuous course of the Kentucky River to the southwest, with a flow opposite the Kentucky River's preglacial drainage direction. From there, it crossed the Madison divide and followed the course of a preglacial northern branch of Salt River-a course generally similar to that of today, except in the vicinity of Cincinnati, where drainage skirted north of the area of the present city in a preglacial loop of channelways.

During the succeeding Aftonian interglacial time, the headwater tributaries of the larger streams dissected the uplands, so relief along the drainageways was increased. Meanwhile, the glacial drift on the undissected uplands was subjected to intensive weathering in place.

When the Kansan ice sheet advanced from the northeast, it deposited glacial drift locally on uplands covered by the earlier, deeply weathered drift of Nebraskan age and in valleys that had been cut below the drift-mantled upland. Reconnaissance studies indicate that in the region of the glaciated Ohio River valley the Kansan ice sheet was less widespread than the Nebraskan, for the ice crossed the river valley only in the vicinity of Cincinnati and west of Madison. The ice is believed to have extended south of the river only for a short time. Resultant drainage modifications were minimal when compared with those produced by the earlier, Nebraskan, and the later, Illinoian, ice sheets. However, as in the Nebraskan age, the drainage channel around the area of the present city of Cincinnati was temporarily blocked. As a result, waters in the valleys of the Licking River and the integrated drainage from the east were ponded. The impounded waters may have temporarily overtopped a col between the Licking River and drainage to the west in the vicinity of the Anderson Ferry along the present Ohio River, west of Cincinnati. Several other drainage bypass channels may have served temporarily to drain the waters impounded in the Ohio and its tributary valleys.

Yarmouth interglacial time began with the withdrawal of the Kansan ice sheet. It was the longest and most important of the three Quaternary interglaciations and a time of long-continued and deep weathering and of active stream erosion. Pre-Yarmouth glacial deposits of Nebraskan and Kansan age are so deeply weathered and so lacking in surface expression, presumably because of surficial erosion, that they are readily distinguishable from the less deeply weathered post-Yarmouth deposits of Illinoian and Wisconsin age, which may retain either wholly or in part vestiges of their original surface expres- 
sion. Although the deep weathering of pre-Yarmouth deposits facilitates their distinction from post-Yarmouth deposits, it prohibits their designation as either Nebraskan or Kansan where only one drift is exposed. Only where two deeply weathered drifts are exposed in stratigraphic succession and are separated by either a pronounced unconformity or a well-defined paleosol, can the Kansan and Nebraskan deposits be distinguished.

Stream entrenchment of the bedrock valleys during Yarmouth time is generally referred to as "Deep Stage" erosion. At the time of greatest stream incision during "Deep Stage" time, local relief was at a maximum; later in Quaternary time, the "Deep Stage" valleys were alluviated, thereby reducing the local relief.

By the close of Yarmouth time, local relief was greater than at any other time during the Quaternary. Therefore, the configuration of the Illinoian, the third great ice sheet to invade the Glaciated Ohio River valley region, was not like that of the earlier ice sheets; the ice was split into two distinct lobes-the Clermont of southwest Ohio and the Jackson of south-central Indiana. The well-known Chestnut Ridge morainic complex in Jackson County, Ind., is interpreted as a border feature along the east margin of the Jackson lobe.

Presumably, the Illinoian ice sheet was prevented by the local relief from invading most of southeast Indiana south of the present border of the Wisconsin ice sheet. Nevertheless, its impact on the formation of the present Ohio River valley was great. Through a series of complex changes, the drainageway looping to the north around Cincinnati was finally abandoned, and the present channel of the Ohio River between the mouths of the Little and Great Miami Rivers was established, as was the present lower course of the Great Miami River. At the close of Illinoian time, the present course of the Glaciated Ohio River valley had been formed.

The Clermont lobe of the Illinoian ice sheet moved into the region of the Glaciated Ohio River valley from the northeast and crossed the valley a few miles above Cincinnati. There it invaded the Kentucky hill lands, forcing drainage from upstream to use briefly the bypass channels in Kentucky that are now prominent terrain features. To the north and west, the ice was deflected in its forward movement by the steep west walls of the broad chutelike valley now in part occupied by the Great Miami River. The ice, lacking sufficient energy to surmount the valley walls and spread over the relatively undissected uplands, was readily diverted as an ice tongue down the broad valley to the Ohio and thence down the Ohio valley to the vicinity of the mouth of the Kentucky River. Vestiges of this ice tongue are present as scattered isolated masses of glacial drift in protected sites along the valley walls, especially along the inner margins of the walls and immediately downstream from the sharp bends of the bedrock valley. Only at one point is there a well-developed kame terrace and a prominent apron of outwash debris adjacent to the valley wall.

Glacial drift of Illinoran age can be distinguished by its relatively modest depth of weathering as compared with depths of weathering of pre-Yarmouth glacial deposits, by its local vestiges of original surface configuration, and by its presence on the uplands as well as in the valley bottoms. When the ice sheet of Illinoian age disappeared from the region of the Glaciated Ohio River valley, the valley was freed of direct association with glacial ice for the last time; although ice of Wisconsin age closely approached the valley, it did not actually invade it.

The Sangamon, the last of the three Quaternary interglacial times, is relatively unimportant to the history of the Glaciated Ohio River valley; during Illinoian time the river channel had been stabilized, so during Sangamon time little change could be accomplished except through weathering of the surficial deposits and through stream degradation. Like all interglacial times, the Sangamon was characterized by stream degradation - the major streams were largely engaged in clearing their valleys of fluvioglacial deposits, and the tributary streams, in their headwater reaches, were engaged in dissection of the adjacent uplands. When Sangamon profiles of weathering are superimposed on the previously weathered surficial deposits of Kansan and Nebraskan age, it is difficult or impossible to separate the Sangamon from earlier profiles of weathering.

The last ice sheet to invade the region of the Glaciated Ohio River valley was the Wisconsin. Areally it was much less extensive than ice sheets of earlier glaciations, for it failed to reach the main Ohio River valley at any point, although a small frontal ice tongue protruded to within a few miles of the Ohio River's main stem at Cincinnati. Despite its lack of direct connection with the Glaciated Ohio River valley, the Wisconsin ice sheet had a profound effect on the valley, which served as a major sluiceway for glacial melt water and fluvioglacial debris which entered the Ohio from the Great Miami River valley and from other tributaries upstream. No melt water or debris, however, entered the Ohio River valley along the south margin of Indiana between the mouths of the Great Miami and Wabash Rivers.

Aggradation during advances of the fluctuating Wisconsin ice sheet and degradation during retreats led to the formation of two prominent terraces along the Ohio River. The highest and oldest, composed of remnants of the great outwash train of Tazewell age, lies above the highest flood levels and provides sites for urban and industrial expansion; it is characterized by low surficial sand dunes and is an excellent source of gravel and ground water. A terrace of less economic importance is slightly lower than the Tazewell terrace and above the present river flood plain. The flood plain represents the last event in the geomorphic history of the Glaciated Ohio River valley. In tributary valleys, terrace remnants underlain by lacustrine silty clays are correlative with the Tazewell terrace and are the result of deposition in the tributary valleys ponded by the outwash train in the main valley. The lower terrace is poorly represented in the tributary valleys.

\section{INTRODUCTION}

The Ohio River, formed by the confluence of the Monongahela and Allegheny Rivers at Pittsburgh, Pa., flows in a generally southwest direction for 981 river miles $^{1}$ to join the Mississippi River at Cairo, Ill., an airline distance of only 546 miles. With a drainage basin of more than 200,000 square miles, the Ohio is the major tributary to the Mississippi from the east. The mean annual flow of 250,000 cubic feet per second for the Ohio River is, however, greater than the mean annual flow of 180,000 cubic feet per second for the main stem of the Mississippi River at the point of confluence of the rivers.

The Ohio River valley is separable into two major parts, an upper and a lower (fig. 1). The upper Ohio River valley, as defined here, is entrenched in the unglaciated and dissected Allegheny Plateau and in the part of the Outer Bluegrass region in southern Ohio and northern Kentucky (Fenneman, 1938). Although some, perhaps all, of the Bluegrass region in Ohio may have been glaciated in early Quaternary, probably Nebraskan, time (Ray, 1969), this possibility is not yet confirmed. Therefore, the downstream limit of the upper Ohio River valley is arbitrarily defined in this report as the point below which continuous deposits of glacial drift are now recognized on both sides of the river

Distances along the Ohio River are given in river miles below Point Bridge, Pittsburgh, Pa., the zero mile established by the Corps of Engineers, U.S. Army. 


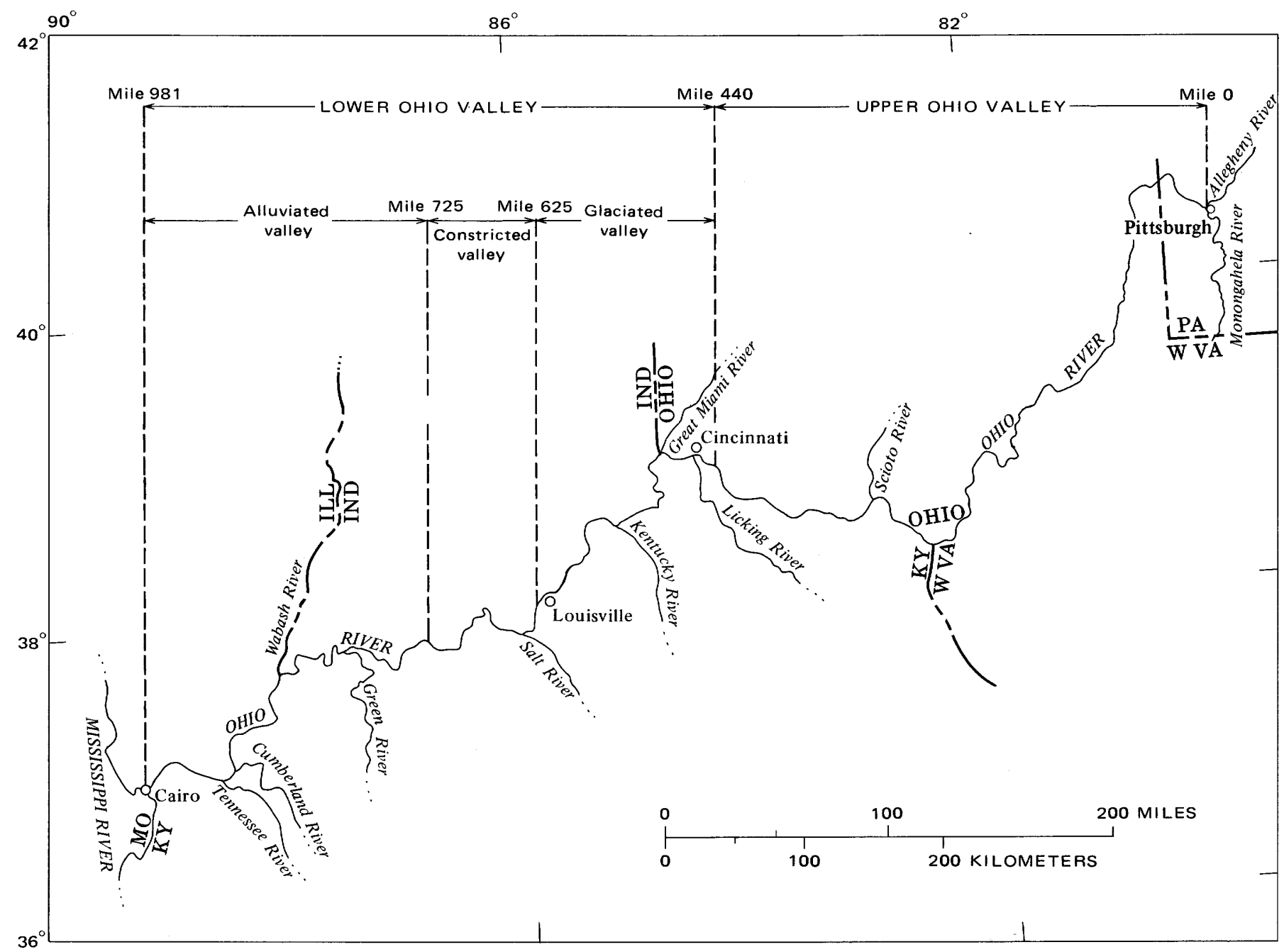

FigURE 1.-Geomorphic subdivisions of the Ohio River valley.

valley-near Mile 440, about 30 miles upstream from Cincinnati, Ohio (fig. 1).

For almost a century the upper Ohio River valley region has been known for spectacular high-level valleys below the general upland surface and commonly 200 feet or more above the present stream levels. These highlevel valleys, the dismembered remnants of a great preglacial drainage system, are an integral part of the history of the present Ohio River drainage basin. However, because the upper Ohio River valley is not part of the present field study, information on it that is utilized in this report has been derived from published studies.

The lower Ohio River valley, from Mile 440 to its confluences with the Mississippi River valley at Mile 981 , is more varied than the upper river valley and is divisible into three distinct sectors (fig. 1). First is the Glaciated sector from Mile 440 to a point immediately downstream from Louisville, Ky. Because the point farthest downstream at which the valley was crossed by Quaternary glaciers cannot be precisely determined, an arbitrary downstream limit for the Glaciated Ohio River valley has been placed at Mile 625 , below Louisville. Near this point the Ohio River enters a narrow, deep, and sinuous gorgelike valley, which forms the second sector, here termed the Constricted Ohio River valley. This sector extends from Mile 625 to Mile 725, near Tell City, Ind., and is unglaciated. The river emerges at Mile 725 from its constricted valley into a broad unglaciated, alluviated valley with extensive bottomlands, back of which rise low rounded valley walls. Although this third sector has a few reaches that are narrow and bounded by steep bluffs, it is here defined as the Alluviated Ohio River valley and extends from Mile 725 to Mile 981 at the confluence of the Ohio and Mississippi Rivers at Cairo, Ill.

In an attempt to present an overall geomorphic history of the present river and its relation to the 
regional development of the landscape and to the Quaternary glaciations, reconnaissance studies were made between 1956 and 1967 of the lower Ohio River valley and the adjacent countryside. A detailed study along a part of the unglaciated and alluviated valley has served as a background for an understanding of many of the problems and regional interpretations (Ray, 1965a). Brief papers, published during the progress of the regional study, have pointed out important observations and preliminary interpretations (Ray, 1957, 1960, 1963a, b 1964, 1965a, b, c, 1966, 1967, 1969; Leighton and Ray, 1965).

The Glaciated Ohio River valley, with which this report is concerned, is of prime importance for an understanding of the entire river system. In earlier studies by others, the intimate relationship of the Ohio River valley to the sequence of Quaternary glaciations and to the effect of these glaciations on the geomorphic history of the valley and adjacent regions has not been adequately clarified. This has led to confusion in the interpretive histories of the glaciated sector of the valley as well as of the unglaciated upper and lower valleys (fig. $1)$, which, although not overridden by the ice, were nevertheless drastically affected by the fluctuations of the ice sheets.

Field investigations consisted primarily of an examination of surficial deposits both within and adjacent to the Ohio River valley and a study of the sequential development of these deposits as related to the regional geomorphic history. Within the bedrock river valley, terrace sequences were studied, and glacial deposits were identified and related to the glacial and alluvial history. Special attention was given to the weathering, regional distribution, and position of the pre-Wisconsin glacial deposits in an attempt to formulate a rational glacial history that could be related to both the river and the regional landforms. Results are presented with the knowledge and hope that future detailed field and laboratory studies of the surficial deposits will augment and perhaps modify the interpretations presented here. Some of these interpretations deviate widely from the commonly accepted beliefs and are presented only after careful weighing of the evidence; others confirm interpretations suggested by earlier workers.

Maps used during field reconnaissance studies were U.S. Geological Survey 71/2-minute topographic quadrangles, scale 1:24,000 (fig. 2). Specific localities referred to in this report can be found on these quadrangle maps.

The writer is indebted to the late Dr. M. M. Leighton, Chief Emeritus, Illinois State Geological Survey, and Consultant, U.S. Geological Survey, for his many visits to the writer in the field during the progress of the present study. His keen and critical field observations, comments, and suggestions based on his long familiarity with Quaternary problems were especially helpful. For 1 month during the summer of 1956 , the writer was ably assisted in the field by E. G. Hasser, whose quick grasp of the problems led to a more efficient utilization of time allotted to field study. The writer, however, assumes full responsibility for all interpretations presented in this report.

\section{REGIONAL SETTING}

The present course of the Glaciated Ohio River valley (fig. 3) is a broad asymmetric loop opening to the south to encompass that part of Kentucky sometimes referred to as the "Northern Peninsula." Although the river is large, its bedrock valley, except in the vicinity of Louisville, is fairly narrow, ranging in width from less than half a mile at Anderson's Ferry (Mile 477.5, Burlington quad., Kentucky-Ohio) to slightly more than 2 miles near Rising Sun, Ind. (Mile 504, Rising Sun quad., Kentucky-Indiana). Above the Louisville area the river is entrenched well below the adjacent uplands. Valley walls are characteristically precipitous, in places rising more than 400 feet above river level. Straight reaches commonly have terraced bottomlands along only one side; valley walls rise almost from the river's edge along the opposite side as mural escarpments of seemingly horizontal stratified bedrock, irregularly notched by small V-shaped creek valleys. Straight reaches alternate with bends, where the convex banks have extensive terraced point bars of agriculturally rich bottomlands. Opposite these point bars, valley walls rise sharply almost from the banks of the river.

Streams directly tributary to the Glaciated Ohio River valley from the north (fig. 3) have small drainage basins except for the Great Miami River (5,290 sq mi) and the Little Miami River (1,770 sq mi). Similarly, there are only two major tributaries from the south, the Kentucky. River $(6,990 \mathrm{sq} \mathrm{mi})$ and the Licking River $(3,660 \mathrm{sq} \mathrm{mi})$. In general, the small tributaries from the north are more steeply graded than those from the south. For a few miles west of Madison, Ind., some of the small tributaries from the north have their steep gradients interrupted by small waterfalls. Of these, the waterfalls of the Clifty Creek basin (Madison West quad., IndianaKentucky, and Clifty Falls quad., Indiana) are best known.

Immediately west of Madison (fig. 3) the divide between those creeks draining directly to the Ohio and those draining west to the Wabash River is less than a mile from the bluffs of the Ohio River valley. Runoff northwest of this divide, so close to the Ohio River, must flow, therefore, for about 300 miles through the Muscatatuck, White, and Wabash Rivers to reach the main stem of the Ohio at the southwest tip of the State of Indiana. 


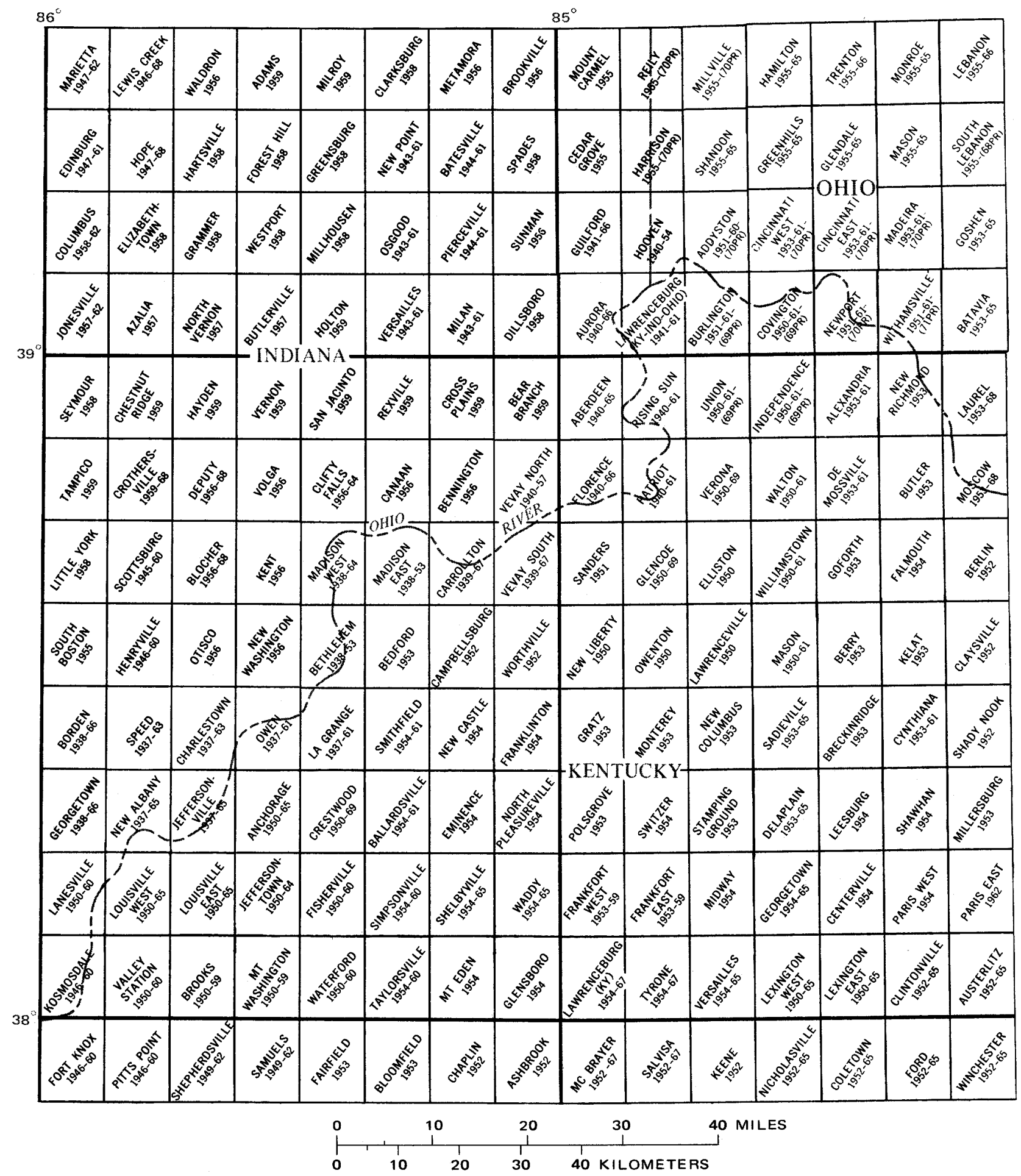

FIGURE 2.-Index to U.S. Geological Survey topographic quadrangle maps, scale 1:24,000, of the Glaciated Ohio River valley and surrounding region.

To understand the diverse character and complex $\mid$ countryside through which the river flows and to which geomorphic history of a feature so relatively recent in origin as the Glaciated Ohio River valley, it is necessary to review the character and geomorphic history of the it is so intimately related. This regional character and history are ultimately dependent on the lithology and structure of the underlying bedrock and on the 


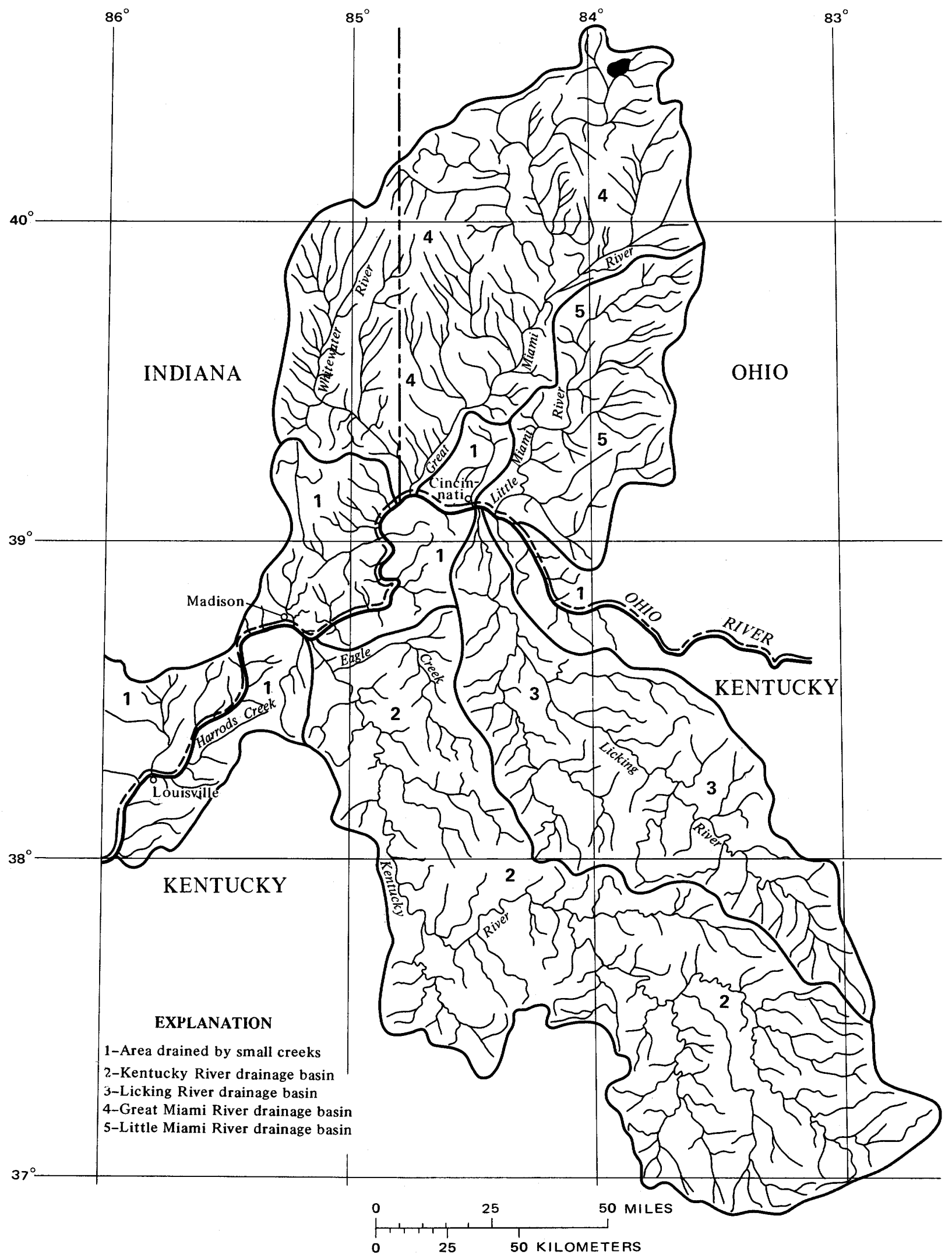

FIGURE 3.-Drainage basins directly tributary to the Glaciated Ohio River valley. Modified from Speer and Gamble (1965). 
geomorphic history of the landscape before the first glaciation of Quaternary age, because the present Glaciated Ohio River valley has been in large part formed by glacial modification of the preexisting drainage network.

\section{PRE-QUATERNARY GEOLOGY}

\section{BEDROCK FORMATIONS AND STRUCTURE}

Bedrock cropping out in the region of the Glaciated Ohio River valley consists of a thick sequence of interbedded Paleozoic shale, siltstone, limy shale, shaly limestone, limestone, and dolomitic limestone that ranges from Middle-Ordovician to Mississippian in age (fig. 4). Between the Appalachian coal basin on the east and the Eastern Interior coal basin on the west, these formations are gently bowed into a broad low anticlinal structure, the Cincinnati arch. The northeast-southwest trend of the arch in the Bluegrass region (fig. 4) is roughly parallel to the trend of the belt of Appalachian deformation, suggesting that the arch may have formed during the Appalachian deformation in late Paleozoic time. The late Paleozoic history of the Cincinnati arch has been lost through erosion and removal of a possible covering of strata of Pennsylvanian age; thinning of the older formations toward the crest of the anticline indicates, however, that the structure antedates the Appalachian deformation and may have resulted from subsidence of the coal basins to the east and west rather than from uplift of the arch itself. (Moore, 1936; Stout, 1941; Lockett, 1947; King, 1951).

Two domal structures have been superimposed on the crest of the Cincinnati arch-the Nashville dome in Tennessee and the Jessamine dome in Kentucky. The Cincinnati arch and the subsidiary Jessamine dome, which lies about 80 miles south of Cincinnati, are the dominant structures in the Glaciated Ohio River valley region and are intimately related to the bedrock outcrops and the landscape along the river.

Erosion of the Jessamine dome has produced an irregular concentric outcrop pattern of Paleozoic formations. In the center, the oldest formation, limestone of Middle-Ordovician age, crops out in a somewhat ovate area whose long axis trends north, roughly parallel to the crest of the Cincinnati arch in this region. The Middle Ordovician is surrounded by younger limestone and shale of Late Ordovician age in a belt of irregular width. This outcrop belt is widest to the north, where strata dip 10 feet or less per mile parallel to the crest of the Cincinnati arch, and is progressively narrower to the south along both the east and the west flanks of the dome, where strata dip 20 to 30 feet per mile away from the crest of the arch. Where the gorge of the present Ohio River transversely crosses the broad crest of the arch at Cincinnati, extensive excarpments of Upper Ordovician limestone and shale along the valley walls show nearly horizontal stratification. Along the south margin of the Jessamine dome, Upper Ordovician formations crop out only in a narrow belt (fig. 4).

Surrounding the outcrop belt of strata of Late Ordovician age are similar belts of successively younger Silurian, Devonian, and Mississippian limestone and shale that dip gently away from the structural high. Only to the north are the belts of concentric outcrops incomplete in this region; there, the Devonian and Mississippian formations are absent. East and west of the area of this report, in the Appalachian and Eastern Interior coal basins, respectively, strata of Pennsylvanian age crop out. Whether strata of Pennsylvanian age formerly extended over the Cincinnati arch and have been removed by later erosion is not definitely known, but the possibility has been considered likely, and correlations across the structure have been attempted (Wanless, 1939).

In the long post-Paleozoic-pre-Quaternary interval, no conclusive evidence has been reported of bedrock formations that would indicate a marine submergence of the area. Presumably the region remained positive during Mesozoic and Cenozoic time and was subjected only to subaerial erosion. Whatever geologic events took place can be interpreted only indirectly through a reconstruction of the geomorphic history and an evaluation of the related surficial deposits.

\section{PHYSIOGRAPHIC DESCRIPTION}

General summaries of the physiography and geomorphic history of the region adjacent to the Glaciated Ohio River valley have been provided by Malott (1922) for Indiana, by Miller (1919) and McFarlan (1943) for Kentucky, and by Fenneman $(1916,1938)$ for Ohio. Each used the Ohio River valley as a political and physiographic boundary. Although convenient, such a boundary is arbitrary and has led to difficulties in presenting a uniform description or a regional geomorphic history.

The Glaciated Ohio River valley.has commonly been used to designate the boundary between two major physiographic provinces-the Interior Low Plateaus (Bluegrass section) and the Central Lowland (Till Plains section) as defined by Fenneman (1931, pl. 1; 1938). Despite the fact that glacial drift of pre-Wisconsin age has been recognized in Kentucky south of the Ohio valley for many years (Ray, 1966), the drift has been ignored beeause it is of limited areal extent and is largely devoid of surface expression and generally so thin that its effect on the landscape is negligible. As pointed out by Thornbury (1965), delineation of the provincial boundary by separation of the glacially controlled topography from the bedrock-controlled topography would be more 

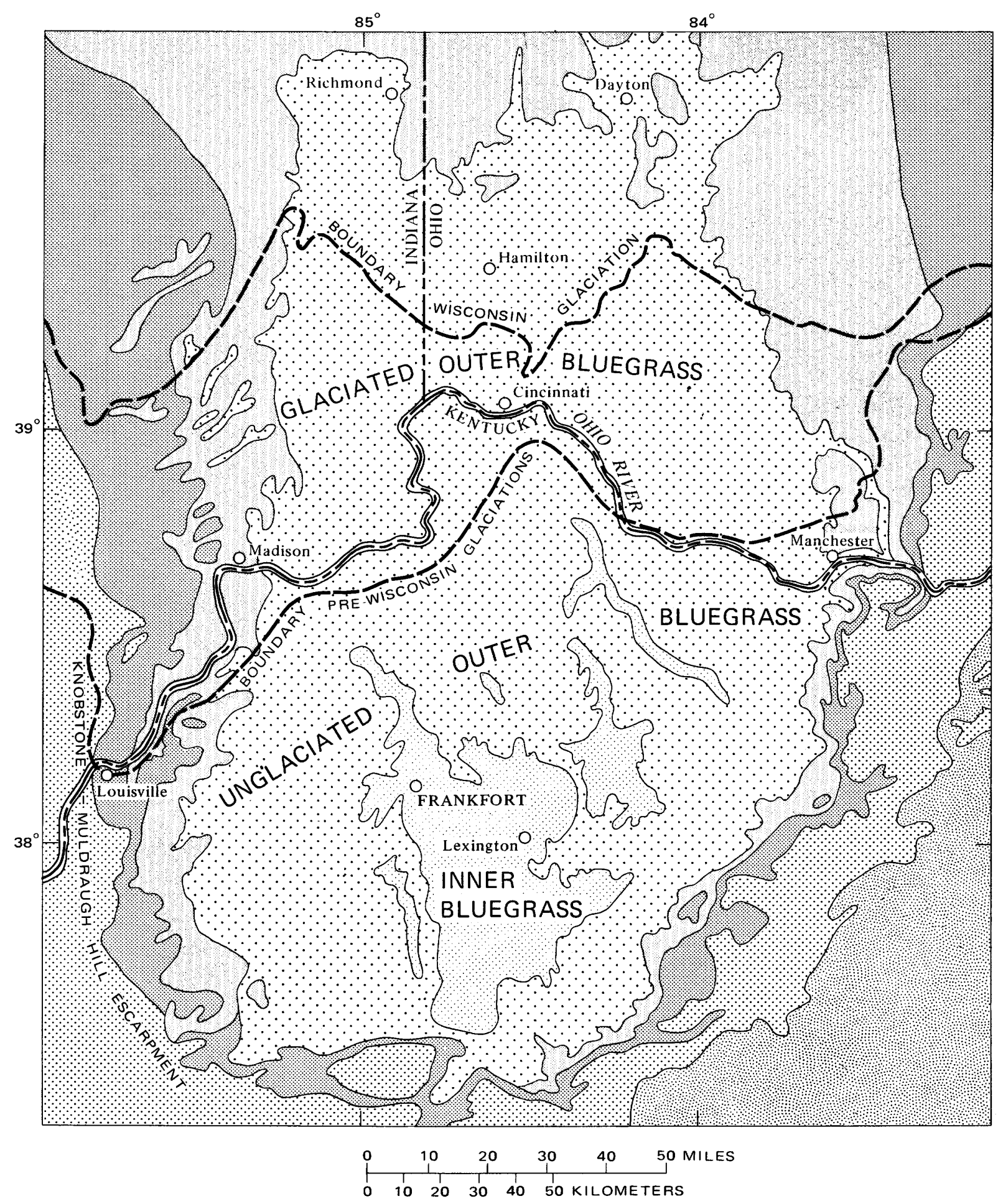

EXPLANATION
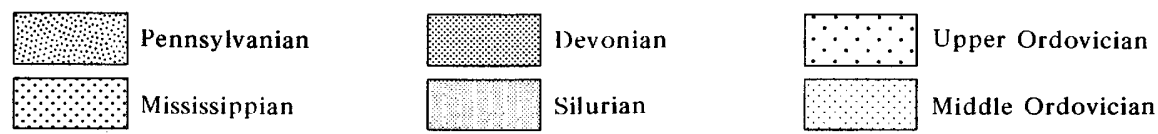

Figure 4.-Generalized geologie map of the Bluegrass region and adjacent areas in Indiana, Kentucky, and Ohio. Modified from the Indiana (Indiana Geol. Survey, 1956), Kentucky (Jillson, 1929; Kentucky Geol. Survey, 1954), and Ohio (Bownocker, 1947) State geologic maps and from other scattered sources. 
satisfactory but less convenient. Only the glacial drift of Wisconsin age, however, has a marked topographic expression and is of sufficient thickness to partly or wholly obscure the bedrock-controlled topography (Malott, 1922). Because the glacial drift of pre-Wisconsin age does not mask the bedrock-controlled topography, the provincial boundary used in this report is placed at the outer, or southern, limit of the till and morainic complex of Wisconsin age in southwest Ohio and southeast Indiana (fig. 4). As a result, the entire Glaciated Ohio River valley and the adjacent countryside, which is mantled by glacial drift of pre-Wisconsin age, are placed in the Bluegrass part of the Interior Low Plateaus province (fig. 4).

Miller (1919), Fenneman (1938), McFarlan (1943), Thornbury (1965), and others have delimited the Bluegrass part of the Interior Low Plateaus province in slightly different ways. The Bluegrass region as defined in this report is broadly interpreted to encompass that area extending from the center of the Jessamine dome west, south, and east to the inward-facing escarpment developed on formations of Mississippian age and north to the southern limit of glacial drift of Wisconsin age (fig. 4). Throughout this area the topography is largely bedrock controlled.

On the basis of lithology and attitude of the bedrock formations, the Bluegrass region is divisible into two distinct regions comprising several physiographic units. The classic Bluegrass region, commonly designated the Inner Bluegrass region, is the fertile rolling plain of deep residual soils formed on the almost flat lying, thinly bedded, and partly phosphatic limestone and shale of Middle Ordovician age that crop out in the center of the Jessamine dome. It is a broad upland, having altitudes generally near 1,000 feet, and is appreciably dissected only where it has been deeply trenched by major streams. Since its formation, the upland surface appears to have been slightly lowered by the solution of bedrock, which has been accompanied by the formation of the characteristic rich residual soils.

The Outer Bluegrass region surrounds the Inner Bluegrass and extends outward to the bounding escarpment of the Bluegrass region. It is characterized by diverse topography; lithology and structure in successive concentric belts of outward-dipping formations of Late Ordovician, Silurian, Devonian, and Early Mississippian age determine the distinctive topography of several irregular terrain units (fig. 4). Where outcrop belts are widest, the characteristic topography is best developed. This is especially true along the west flank of the Cincinnati arch, both north and south of the Glaciated Ohio River valley. There, the pre-Wisconsin glacial deposits are so thin that they do not mask the basic bedrock control of the topography.
The area underlain by thinly bedded limestone and shale of Late Ordovician (Eden) age is, where undissected, an upland of low relief. Its altitude is generally comparable to that of the Inner Bluegrass and ranges from about 800 to about 1,000 feet. In large part it is topographically similar to the Inner Bluegrass, but residual soils developed from bedrock and from glacial drift of pre-Wisconsin age are thinner and less fertile. Adjacent to the major streams, which are now entrenched several hundred feet below the general upland surface, a mature topography of steep-sided narrow rocky and relatively infertile ridges and elongate spurs has resulted from deep dissection and headward erosion of tributaries. Only the even skyline of the dissected areas indicates the existence of the former upland surface.

That part of southeast Indiana underlain by the Upper Ordovician formations has been termed the Dearborn upland by Malott (1922). In his description of this area, which is comparable to the Outer Bluegrass of Kentucky, he pointed out that it extends eastward into Ohio and southward into Kentucky and that it is obscured to the north by the mantle of thick glacial deposits of Wisconsin age.

Surrounding the central core of exposed Ordovician formations is an almost continuous belt of Silurian formations whose outcrop in the Bluegrass section is widest on the flanks of the Cincinnati arch, just south of the limit of glacial drift of Wisconsin age (fig. 4). Farther south, the belt of outcrop becomes progressively narrower as the Silurian formations become thinner. Along the south margin of the Outer Bluegrass, outcrops of the Silurian formations are absent, for, as reported by McFarlan (1943), the formations of Silurian age are cut out by the progressive overlap of Middle Devonian formations onto formations of Late Ordovician age.

Inasmuch as the Silurian formations are generally more resistant to erosion than the underlying Ordovician formations, a well-defined cuesta has formed along the inner margin of the west-dipping Silurian formations on the west flank of the Cincinnati arch south of the Wisconsin glacial boundary. This prominent north-trending cuesta is a well-developed drainage divide in Indiana and for about 15 miles south of the Ohio River in northern Kentucky. In Indiana it is known as the Laughery escarpment (Malott, 1922).

West of the Silurian cuesta, an erosional plain of slight relief has formed in Indiana and northern Kentucky by the stripping of the overlying, less erosion resistant formations of Late Devonian and Early Mississippian age from the underlying more resistant Lower Devonian and Silurian formations that dip west and southwest at approximately 15 feet per mile. The 
general surface of this physiographic unit of the Outer Bluegrass, almost parallel to the dip slope of the formations, has been named and described in Indiana by Malott (1922) as the Muscatatuck regional slope. He noted (p. 86) that "across the Ohio River in Kentucky it [the Muscatatuck regional slope] is well represented and is usually considered a part of the Bluegrass Region." The drainage divide along the Laughery escarpment marks the east edge of the regional slope in Indiana and separates drainage to the west from that of the Dearborn upland to the east (fig. 3). In Kentucky, as the formations of Silurian age become progressively thinner, the drainage divide, so well defined north of the Ohio River in Indiana, disappears (figs. 3 and 4).

At Madison, Ind., at the east edge of the Muscatatuck regional slope, the Ohio River transects the northtrending Laughery escarpment and drainage divide in a deep and narrow valley with precipitous walls. Downstream, to the southwest, where the Ohio River crosses the Muscatatuck regional slope, valley walls remain precipitous but are somewhat lower. Streams generally flow in conformity with the regional slope (Culbertson, 1908, 1916), which in places they have deeply dissected, leaving interstream areas as gently sloping upland flats. In places, the larger streams have cut through the Silurian formations into the Upper Ordovician strata (fig. 4). Near the poorly defined west margin of the regional slope, erosional remnants of the overlying limestone and shale of Devonian age are present on the interstream flats.

The gently west dippıng bedrock of Silurian age and the related dip slope, the Muscatatuck regional slope, are in marked contrast to the Dearborn upland to the east, which is underlain by the almost flat lying Ordovician beds near the crest of the Cincinnati arch. The Muscatatuck regional slope descends from an altitude of slightly more than 900 feet at its east margin, at the crest of the Laughery escarpment, to merge on the west along an indefinite margin with a broad lowland near 500 feet in altitude-a descent of almost 400 feet in about 25 miles.

The lowland at the foot of the regional slope is formed on a belt of easily eroded limestone, shale, and siltstone of Devonian and Mississippian age. Although the physiographic unit is best represented north of the Ohio River valley, where it has been described and named the Scottsburg lowland (Malott, 1922), it extends for a few miles south of the river in the vicinity of Louisville, $\mathrm{Ky}$. (McFarlan, 1943). Elsewhere, control of the topography by this belt of bedrock outcrop is less well defined, and the lowland is poorly developed. The west boundary of the Scottsburg lowland is the prominent KnobstoneMuldraugh Hill escarpment, ${ }^{2}$ which marks the outer boundary of the Bluegrass region.
Two major streams flowing down the Muscatatuck regional slope-the combined Muscatatuck-East Fork of White River and the combined Ohio-Salt River-cross the Scottsburg lowland and plunge into deep valleys cut through the Knobstone-Muldraugh Hill escarpment (figs. 3 and 4). On the lowland, small creeks tributary to these major streams flow in courses roughly parallel to the general north-south axis of the lowland, and their headwaters are separated by inconspicuous divides.

The pre-Wisconsin glacial deposits that mantle most of the Scottsburg lowland north of the Ohio River appear to have had little effect on bedrock control of the topography. The general relations of the lowland to the Wisconsin glacial deposits, however, long ago suggested to Collett (1882) that the lowland was once part of an ancient river valley - a sluiceway for glacial melt-water torrents draining to the Ohio River. No field evidence has been found to support this suggestion.

The conspicuous inward-facing Knobstone-Muldraugh Hill escarpment of siltstone, shale, and sandstone, capped by resistant limestone of Mississippian age, almost completely encircles and delimits the Bluegrass region south of the limit of the Wisconsin glacial deposits. It is best developed, however, along the west flank of the Cincinnati arch in Indiana, where it separates the Scottsburg lowland from the Norman upland (Malott, 1922) to the west. In Indiana it rises in places more than 500 feet above the Scottsburg lowland and is reported by Malott (1922) to be the most prominent topographic feature of the State. South of the Ohio River in Kentucky, the escarpment, known as Muldraugh Hill, is a nearly continuous topographic feature that delimits the Bluegrass region. Where the escarpment has been dissected by stream erosion, an irregular belt of projecting spurs, flat-topped outliers, and steep-sided knoblike hills has formed, producing a terrain wholly unlike that of the Bluegrass. This belt, locally known as "The Knobs," is excluded from the Blugrass region.

According to the interpretation here proposed, the Glaciated Ohio River valley lies wholly within the glaciated part of the Bluegrass section of the Interior Low Plateaus province. Its sinuous course crosses the Cincinnati arch-Jessamine dome structure and all physiographic units of the Bluegrass region except for the Inner Bluegrass on the structural crest of the Jessamine dome. Below Louisville, the river leaves the Bluegrass region through a deep gorge cut into the Knobstone-Muldraugh Hill escarpment and the upland to the west. At the head of this gorge the Glaciated Ohio River valley becomes the Constricted Ohio River valley (fig. 1).

${ }^{2}$ The escarpment names, Muldraugh Hill in Kentucky and Knobstone in Indiana, have been combined for use in this report (fig. 4). 
PRE-QUATERNARY GEOMORPHIC AND DRAINAGE DEVELOPMENT

The long interval between deposition of the youngest known marine formation in the Bluegrass region in late Paleozoic time and the invasion of the northern part of the region by the earliest ice sheet of Quaternary age lacks tangible stratigraphic evidence that can be used to reconstruct a sequence of geologic events. Lack of marine sediments of Mesozoic and Cenozoic age has led to the generally accepted belief that since late Paleozoic time this area has been continuously above sea level and subject to subaerial erosion. The history of this area is, therefore, geomorphic and of necessity begins with the oldest recognizable landforms and their associated unconsolidated deposits. These are the high-level fluviatile sands and gravels and the widespread rolling uplands which, near major streams, are commonly so deeply dissected that they are represented now only by relict upland flats, ridge crests, and isolated hilltops with locally accordant altitudes. Relief on the rolling upland surface is generally not more than 100 to 200 feet.

This ancient surface, now at an altitude generally between 900 and 1,000 feet or more in the Inner Blugrass, is the Lexington peneplain of Campbell (1898). Although somewhat lower in altitude, it has been correlated regionally with the Highland Rim peneplain of Hayes (1899) by Malott (1922) for Indiana, by McFarlan (1943) for Kentucky, and by Fenneman (1938) and Thornbury (1965). Despite the fact that this surface has been assigned different ages, it is believed to have been formed by middle Tertiary, presumably late Miocene, time (Ray, 1965a, p. 21-22). Formation of this gently rolling upland of low relief required regional uplift to destroy the environment of marine sedimentation and to initiate an environment of subaerial erosion. This may have begun in late Paleozoic, perhaps postPennsylvanian time, although evidence is lacking.

In the Bluegrass region, where the Cincinnati arch and Jessamine dome structures had been outlined, the regional uplift set the stage for long-continued subaerial erosion. Reduction of the Bluegrass region to a surface of moderately low relief that truncated bedrock structure was dependent upon the rock characteristics and the erosional capacity of the streams, whose drainage may have been directed, for the most part, to the Mississippi embayment several hundred miles to the southwest. Whether the regional uplift was preceded by other periods of uplift and erosion is not known, although the possibility has been suggested (Campbell, 1898; Fenneman, 1938). Suffice it to say that by late Miocene time the Bluegrass region appears to have been a surface of moderate relief that truncated the regional bedrock structure and was perhaps only a few hundred feet above sea level.
Continued differential erosion, aided by solution of the Ordovician formations, produced a broad shallow basin rimmed on the east and west flanks of the regional structure by inward-facing escarpments of the more erosion-resistant formations of Silurian age. Along the north margin of the basin, dip of bedrock across the gently north-plunging crest of the Cincinnati arch is so low that the almost horizontal Silurian formations crop out today in a broad belt with no well-defined escarpment. Along the south margin of the basin, where formations of Silurian age are absent, an escarpment capped by erosion-resistant limestone of Mississippian age (fig. 4) presumably formed contemporaneously.

Although the characteristics of the drainage net on this ancient surface are not precisely known, streams of low gradient may have flowed in wide sinuous shallow valleys with broad low interstream divides (Fenneman, 1938). In that part of the Bluegrass region circumscribed by the escarpment of formations of Silurian age, drainage appears to have been generally to the north, except in the southwestern part, where drainage was to the west.

A regional uplift, initiated in late Miocene-early Pliocene time, is postulated to have raised the surface of low relief, resulting in rejuvenation of stream activity. The uplifted surface appears to have been tilted in part to the west and southwest and in part to the north and northwest (Fenneman, 1938; Horberg, 1950; Thornbury, 1965). At this time there may have been no drastic rearrangement of the earlier drainage net; rather, the major stream pattern may have continued with only minor readjustments, stream entrenchment, and valley widening.

Stream entrenchment into the upland surface was described by Butts $(1904$, p. 3), who noted that bedrock terraces or benches in the Allegheny Plateau were "remnants of a former broad valley floor bounded by high steep walls***". He suggested that "It has been customary to call such a broad valley floor a gradation plain," but that "for the sake of brevity, the term strath is here introduced***," and "the name Parker is adopted because the strath is well preserved at Parker on the Allegheny***." Since first proposed by Butts, the concept of the Parker strath has been extended regionally (Fenneman, 1938; Stout and others, 1943; Thornbury, 1965) and has at times been referred to as an "incipient" or "partial peneplain" stage formed below the uplifted Lexington surface in post-Miocene, presumably Pliocene, time.

In Parker (Pliocene) time, major streams, such as the Kentucky and Licking Rivers, flowed across the Ordovician formations in the broad shallow basin of the Bluegrass region and cut valleys in places as much as 150 to 200 feet below the gently rolling Lexington sur- 
face. At the same time, stream erosion produced the Muscatatuck regional slope west of the north-trending Laughery escarpment defined by the Silurian formations on the west flank of the Cincinnati arch.

Many attempts have been made to unravel the overall pattern and character of the pre-Quaternary drainage of the North Central States, especially as they are related to the complex history of the present Ohio River from the ancient drainage systems prior to the advance of the first Quaternary glaciers (James, 1888, 1891; Wright, 1890; Leverett, 1902; Tight, 1903; Fenneman, 1914, 1916; Malott, 1922; Fowke, 1933; Stout and others, 1943; Horberg, 1945, 1950; Wayne, 1952, 1956; Coffey, 1958; and others). Although it is generally agreed that a large part
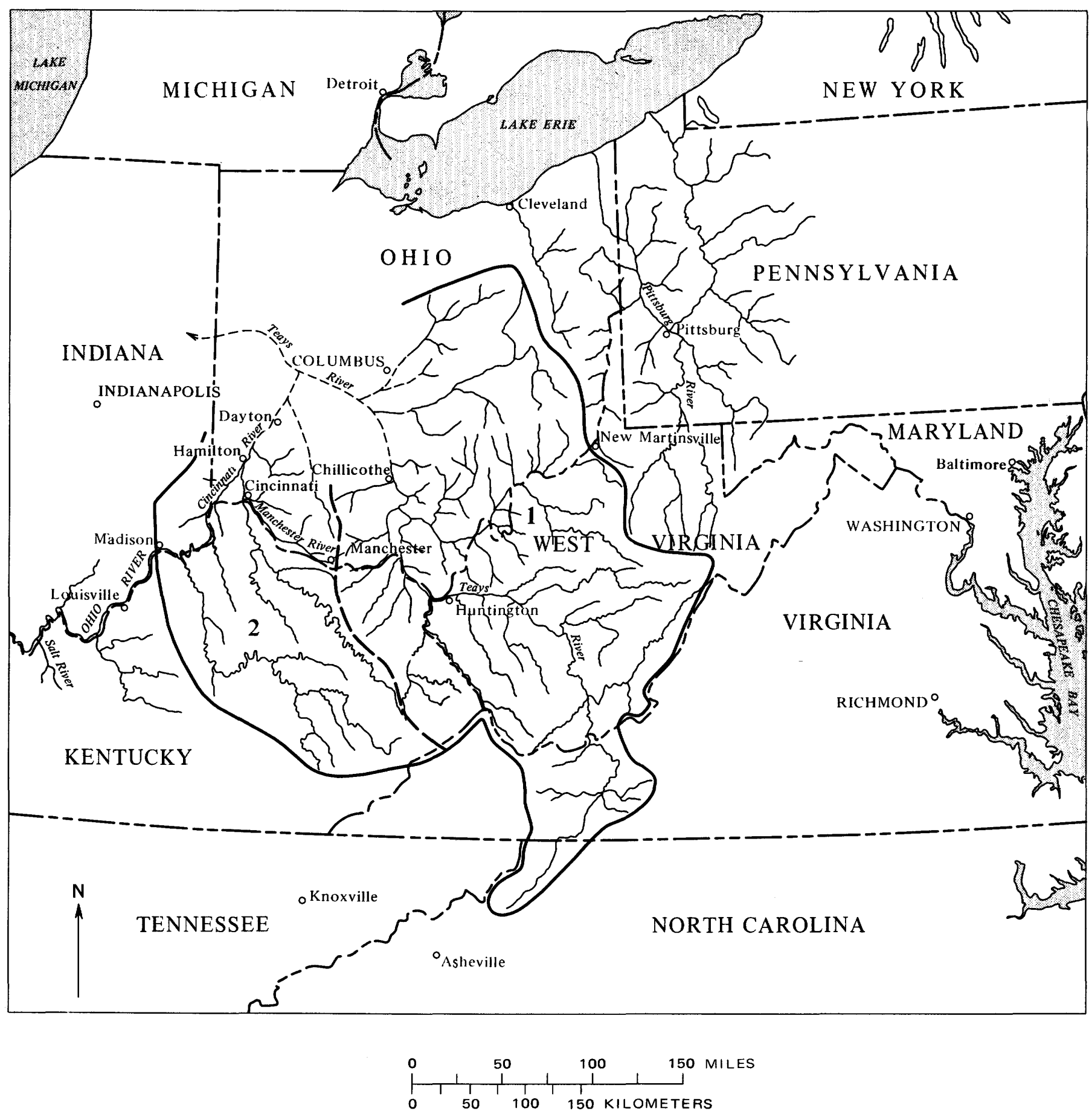

Figure 5.-Preglacial drainage basin of the upper Teays River. Modified from Tight (1903). 1, Drainage basin of the main stem of the Teays River. 2, Drainage basin of the Cincinnati River, a major tributary of the Teays River. 
of the present upper Ohio valley drainage, above New Martinsville, W. Va. (fig. 5), was to the north, perhaps to the Atlantic through an ancient St. Lawrence valley, many conflicting hypotheses have been formulated for the Glaciated Ohio River valley. Each is based on the presumption that the present Ohio River did not exist as a through-flowing stream until after modification of the preglacial drainage pattern by Quaternary glaciations.

It is generally agreed that the master stream of the North Central States did not cross the Bluegrass region in pre-Quaternary time; rather, it skirted the region on the east and north, avoiding the structurally highest part of the Cincinnati arch-Jessamine dome structure. The first evidence cited for this master stream was an abandoned river valley in West Virginia (Wright, 1890). Referred to as the Teazes (Teays) by Wright, this ancient abandoned valley was entrenched below the upland surface in what has become known as Parker (Pliocene) time. Studies, especially by Tight (1903), indicated that the Teays River system had its headwaters in North Carolina (fig. 5) and flowed to south-central Ohio. The valley was traced by Tight to the vicinity of Chillicothe, Ohio, where it disappeared beneath a mantle of glacial deposits. Accumulated drilling and seismic records have shown with a high degree of certainty that the valley beneath the obscuring glacial deposits extends northwest from Chillicothe, across Ohio and Indiana, to join the buried Mahomet valley of central Illinois (Stout and others, 1943; Horberg, 1945, 1950; Wayne, 1956). The combined river, here called the Teays-Mahomet, was the major stream of the North Central States and was tributary to an ancient Mississippi River that drained to the Gulf of Mexico (Horberg, 1945).

Strong differences of opinion exist whether drainage of the Bluegrass section was tributary to the ancient Teays-Mahomet River to the north or was tributary to an ancient southwest-flowing Ohio River that also drained to the Mississippi embayment.

Leverett (1902), Tight (1903), Fenneman (1916), Fowke (1933), Stout and Lamb (1938), and Stout, Ver Steeg, and Lamb (1943) have placed a preglacial drainage divide along the present Ohio River valley near Manchester, Ohio, about 70 river miles upstream from Cincinnati. This postulated divide is about 35 miles west of the point where the main stem of the preglacial Teays River crossed the present Ohio River valley (fig. 5). Whether the divide near Manchester separated an asymmetric Teays-Mahomet drainage basin from the basin of an ancient Ohio River, or whether it separated drainage of the main stem of the Teays-Mahomet River from that of a major tributary, has been a matter of speculation.

The ancient preglacial stream heading on the west side of the Manchester divide is the Manchester River of Fowke $(1925,1933)$ or the Norwood River of Stout, Ver

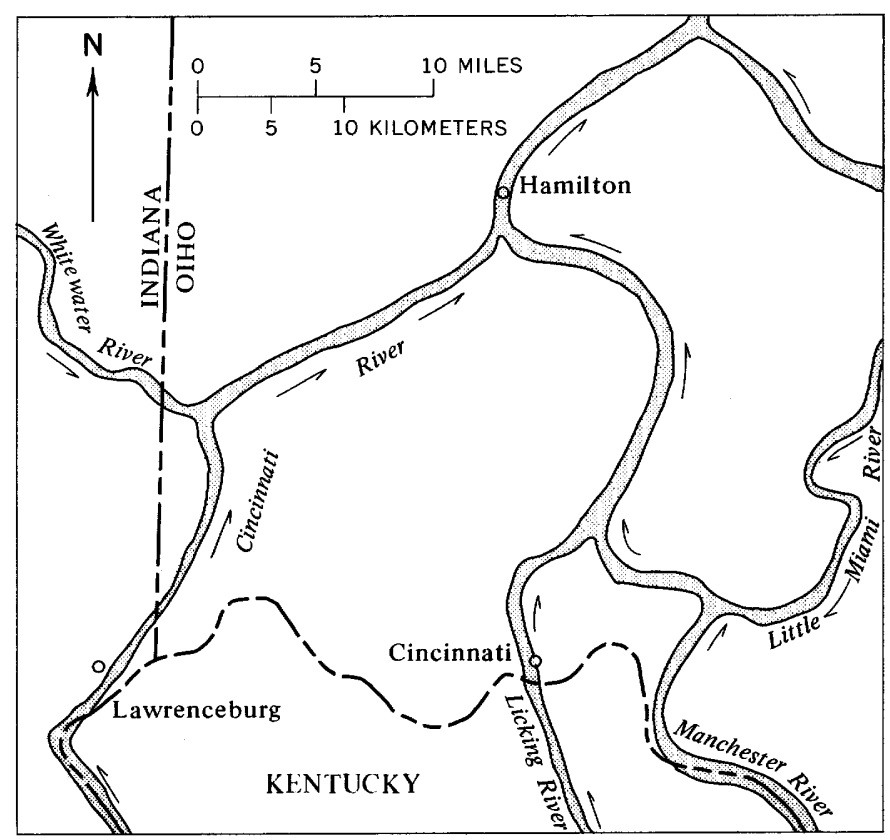

FIGURE 6.-Major preglacial drainage channels in the vicinity of Cincinnati, Ohio. Modified from Fenneman (1916).

Steeg, and Lamb (1943). Its high-level valley is believed to have followed more or less closely the northwest course of the present Ohio River valley to the mouth of the Little Miami River valley in the east part of Cincinnati.

The preglacial net of stream valleys in the vicinity of Cincinnati (fig. 6) is well known (James, 1891; Fenneman, 1916, 1938; Thornbury, 1965). Briefly, the Manchester River of Fowke flowed up the present Little Miami River valley, its flow reversed from that of the present stream, and through the Norwood trough to join the ancient Licking River at the head of the nowabandoned trough. The north-flowing Licking River is believed to have crossed the site of the present Ohio River and continued to the north, essentially along the course now followed by the south-flowing Mill Creek through the heart of Cincinnati, to its confluence with the Manchester River. The ancient combined Manchester-Licking River continued northwest and, south of Hamilton, Ohio, joined a major stream occupying the ancient broad high-level valley that is now in large part followed by the Great Miami River. Whether this major stream had a reversed flow to the north, as the Cincinnati River of Tight (1903) (figs. 5 and 6), or a flow to the south, as the Hamilton River of Stout, Ver Steeg, and Lamb (1943) (fig. 7), has been a subject of discussion for many years.

According to Fowke $(1898,1900,1925,1933)$, Tight (1903), Malott (1922), Wayne (1952), and others, a preglacial drainage divide similar to that at Manchester 


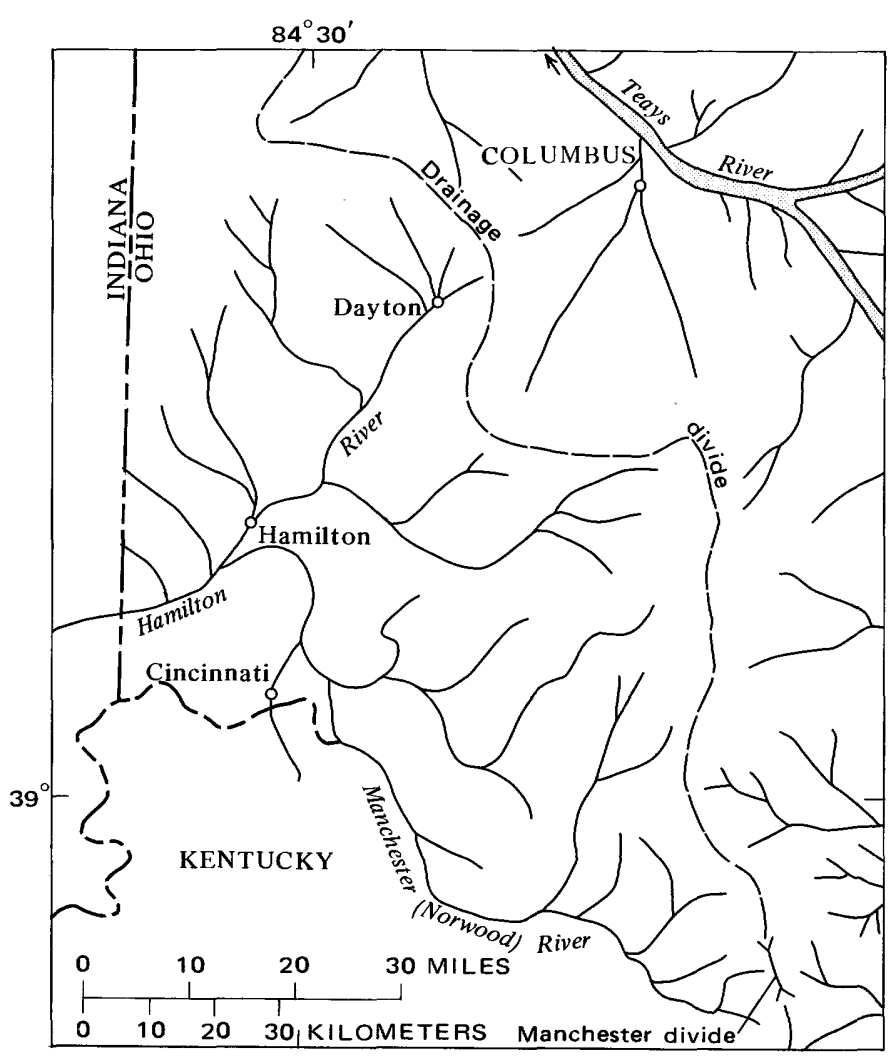

Figure 7.-Preglacial drainage in southwest Ohio. Modified from Stout, Ver Steeg, and Lamb (1943).

was present along what is now the Ohio River valley at Madison, Ind. (figs. 5 and 8). They believed that drainage east of the Madison divide had a reversed flow to the northeast up the present Ohio valley and then the Great Miami valley as the Hamilton River (same as the Cincinnati River of Tight (1903)) to join the combined Manchester-Licking drainage near Hamilton. From there, drainage continued north as a major tributary to the ancient Teays-Mahomet River.

On the other hand, Stout, Ver Steeg, and Lamb (1943), following James $(1888,1891)$, and Leverett (1902), placed a preglacial drainage divide near Dayton, Ohio (fig. 9). They believed that this divide would have blocked a north-flowing Hamilton River (Cincinnati River) from the basin of the Teays-Mahomet River. Therefore, they proposed that near Hamilton, Ohio, the Manchester (Norwood) River was tributary to a south-flowing Hamilton River. According to this proposal, the Hamilton River headed along a divide northeast of Dayton that separated its basin from that of the main Teays-Mahomet River; therefore, the combined Hamilton-Manchester River was forced to flow southwest along the broad valley now in large part occupied by the Great Miami River to reach the preglacial Ohio River that flowed southwest, as it does today, across the Madison divide of Fowke and others (fig. 8).
Resolution of the preglacial drainage pattern is thus dependent on the validity of two of the three proposed preglacial drainage divides. Each of these postulated divides is along the outcrop belt of erosion-resistant Silurian formations that dip outward from the Cincinnati arch-Jessamine dome structure.

The first divide, near Manchester, Ohio, on the east flank of the structure (figs. 5 and 7-9), separated the basin of the ancient preglacial Teays River from that of the Manchester (Norwood) River. This divide has been generally accepted and has not been the subject of controversy. The second divide, north or northeast of DaytonOhio (figs. 7 and 9), is presumed to have spearated the Teays River basin from drainage of the Bluegrass region. If the second divide is valid, then the third divide, at Madison, Ind. (figs 5 and 8), could not have existed, for it would have blocked the drainage to the southwest along a preglacial Ohio River valley. If, on the other hand, there was no drainage divide in the Dayton area, but a divide at Madison, as urged by Fowke (1925, 1933), Malott (1922), and Wayne (1952, 1956), drainage of most of the Bluegrass region would have been tributary to that of the ancient TeaysMahomet system, and the headwaters of the preglacial Ohio River would presumably have been west of the Madison divide. It is essential, therefore, to consider the validity of these two important divides-the one near Dayton and the one at Madion-in order to determine the preglacial drainage $o$ the Bluegrass region and of the Ohio River.

Leverett (1902) and Fenneman (1914, 1916), following James (1891), placed the headwaters of the preglacial Ohio at the Manchester divide and believed that drainage was to the vicinity of Hamilton, Ohio, and thence to the southwest, in general following the course of the present Great Miami and Ohio Rivers to and beyond the Madison divide (fig. 9) Stout, Ver Steeg, and Lamb (1943) suggested that the broad valley leading northeast from Hamilton to the Dayton area and beyond, now occupied by the Great Miami River, formerly contained a major stream, the Hamilton River, that flowed southwest from a divide north or northeast of the Dayton area (fig. 7). They postulated that the Hamilton River was "formed by the convergence of tributaries at Dayton" (1943, p. 70), and, following Leverett and Fenneman, they believed that it continued southwest, joining the larger Manchester (Norwood) River, which headed on the Manchester divide.

Norris and Spieker (1966) reviewed the two opposing theories of preglacial drainage (figs. 7 and 8 ) and of the presumed divide northeast of Dayton. On the basis of their field studies, available drilling records, and contouring of the bedrock surface beneath the mantle of glacial deposits, they concluded $(1966$, p. 22$)$ that "the 
direction of flow in the Dayton area of the Teays Stage streams (south, as Stout, Ver Steeg, and Lamb state, or north, as Wayne believed) is a matter of speculation for the time being," and, furthermore (p. 23), that "elements of both concepts may be correct." They suggested, but did not critically analyze, a theory that the Hamilton River may have initially had a southward flow which was later reversed by capture through headward erosion of a tributary of the Teays-Mahomet River. They also pointed out that possible passages known to cross the drift-mantled drainage-divide area near Dayton appear too narrow to have accommodated a north-flowing stream having a drainage basin the magnitude of the north-flowing Hamilton (Cincinnati) River system.

Although Stout, Ver Steeg, and Lamb (1943, p. 68) stated that "the [Hamilton River] outlet was along the valley of the present Ohio River to where this old tributary joined the master Teays near the mouth of the present Wabash," their map (fig. 7) indicates that the Hamilton River did not join the Ohio near the present mouth of the Great Miami, but seemingly entered Indiana at the mouth of the present Whitewater River valley (fig. 3$)^{3}$

An alternative hypothesis suggested by Durrell (1961) was that the preglacial drainage was directed to the southwest from the Hamilton, Ohio, area, to and up the present Whitewater River valley, across the Silurian cuesta (Laughery escarpment) in southeast Indiana, and along the preglacial Anderson Valley (fig. 8; Wayne,

'Since the study of Stout, Ver Steeg, and Lamb (1943), accumulated information has demonstrated that the Wabash River was not part of the preglacial Teays-Mahomet River system (Wayne, 1952, 1956; Thornbury, 1965) but was tributary to the preglacial Ohio (figs. 8 and 9).

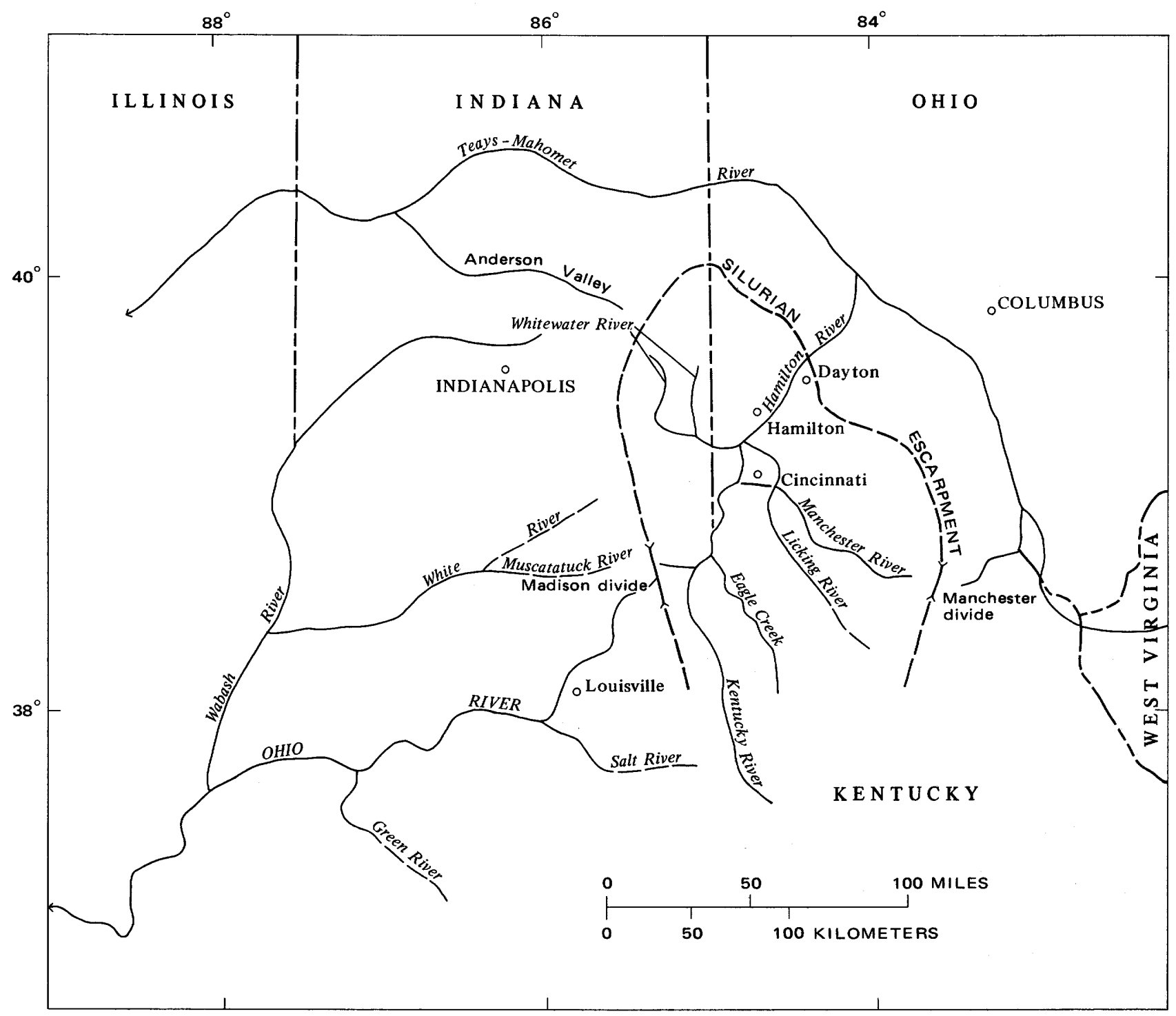

FIGURE 8.-An interpretation of preglacial drainage of the Teays-Mahomet,Ohio, and other rivers. Modified from Fowke (1898, 1900, 1925, 1933), Malott (1922), Wayne (1952), and others. 


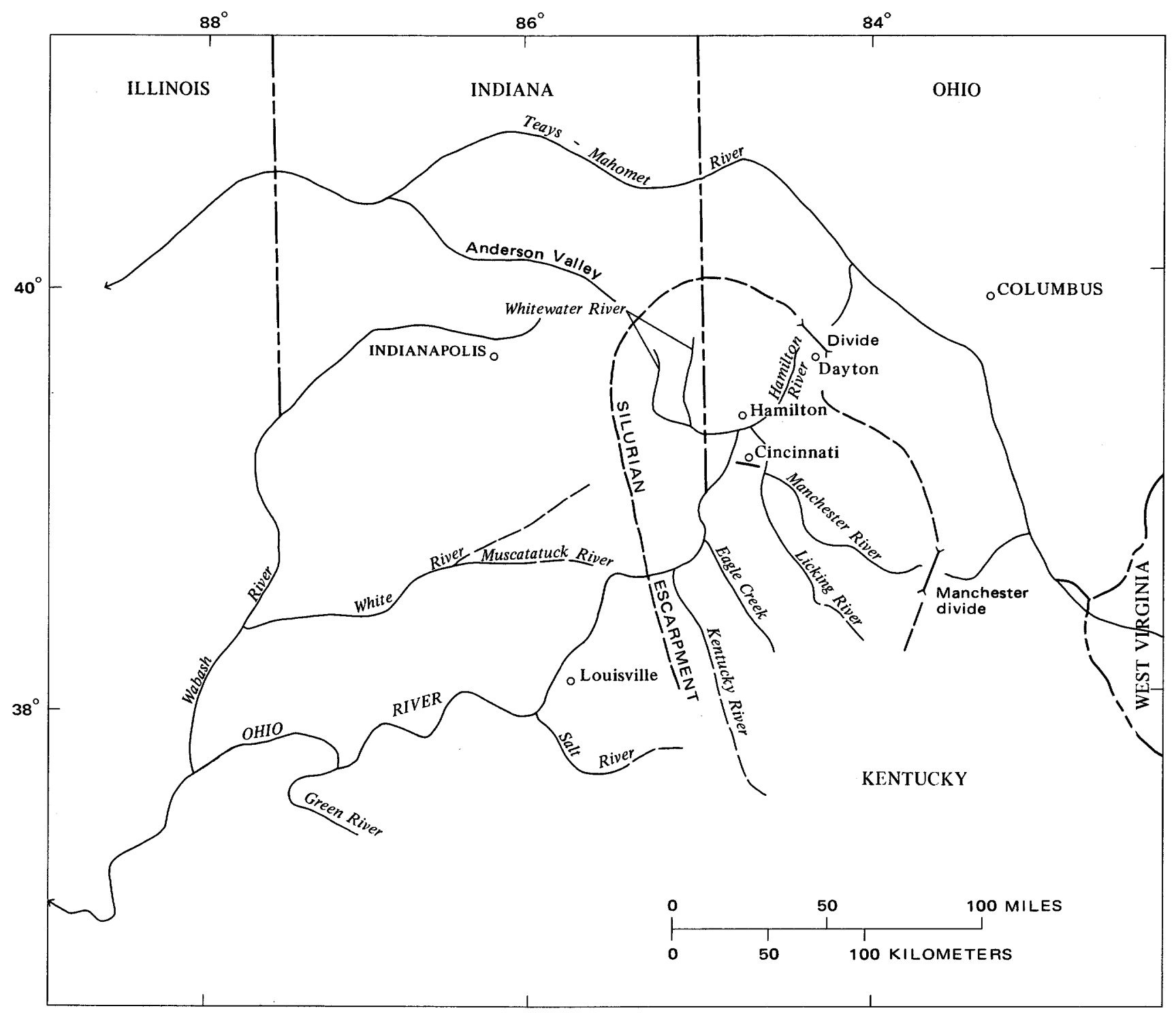

Figure 9.-An interpretation of preglacial drainage of the Teays-Mahomet, Ohio, and other rivers. Modified from Leverett (1902), Fenneman (1914, 1916, 1938), Stout, Ver Steeg, and Lamb (1943), and others.

1952, 1956), a tributary of the preglacial Teays-Mahomet River. Such a drainage pattern implies the existence of a drainage divide near Dayton. Inasmuch as no mention was made of drainage from the Kentucky River basin, one cannot be certain whether Durrell inferred a drainage divide at Madison. His map (1961, fig. 2), however, indicates that the preglacial Eagle Creek in northern Kentucky flowed up the present Ohio and Great Miami River valleys to the vicinity of Hamilton, Ohio, thence on to the north, thereby implying that no divide separated this north-flowing stream from the main stem of the Teays-Mahomet River. No drainage from the east along the preglacial course of the Manchester (Norwood) River is shown on Durrell's map. Durrell's alternative hypothesis of drainage through the Whitewater River and, by inference, the Anderson Valley appears unlikely in view of Wayne's report (1952) that the preglacial Anderson Valley headed near the crest of the Laughery escarpment in southeast Indiana. The deep narrow gorge across the escarpment, now buried under glacial drift, is, according to Wayne, the result of Quaternary erosion by overflow waters from a proglacial lake that occupied Anderson Valley. If this is true, there was no continuous Whitewater-Anderson valley that could have served as a drainageway in preQuaternary time.

Much evidence has been marshalled by Malott (1922, p. 138-139) in support of a drainage divide following the crest of the Laughery escarpment at Madison, Ind. He pointed out that the narrow steep-sided valley of the 
present Ohio at Madison is obviously young and is cut below a relatively smooth and undissected upland that lacks ancient channelways across it either north or south of the present river gorge. Furthermore, he noted that fluviatile gravel deposits are absent on the upland surface in the Madison area, whereas ancient gravel deposits are reported along the high-level valleys of the preglacial Eagle Creek; the Kentucky, Licking, and Salt Rivers; and the Ohio River below Louisville. He failed, however, to distinguish between gravel deposits on the uplands and those in the high-level stream channels cut below the upland surface.

Malott (1922) and others have called attention to the fact that small tributaries of the present Ohio River between Madison and the mouth of the Kentucky River would have joined normally an ancient stream flowing northeast from a divide at Madison, but that today, a reversal of flow having resulted from Quaternary glacial modifications of the drainage, the tributaries are barbed. If, however, the argument based on the barbed drainage is examined further, it does not adequately explain all tributary relations between the mouths of the Kentucky and Great Miami Rivers. Along this section of the Ohio River valley, some stretches have barbed tributaries, whereas other stretches have normal tributaries. ${ }^{1}$ This seemingly anomalous situation is readily explained, however, on the basis of the configuration of a high-level preglacial channel of the Kentucky River that drained to the northeast.

Along the Glaciated Ohio River valley between Miles 488 (Lawrenceburg quad., Kentucky-Indiana-Ohio) and 541 (Vevay South quad., Kentucky-Indiana), a high-level preglacial channel can be reconstructed that was sinuous, narrow, similar to, and a continuation of the high-level preglacial channel of the Kentucky River above its present confluence with the Ohio (fig. 10; Jillson, 1946). Where the present Ohio River valley is a modified segment of the sinuous preglacial valley, tributary streams are now barbed; where the present valley is the result of Quaternary drainage modifications resulting from glaciation, tributaries now join the main valley normally. Evidence of similar barbed drainage has been recognized by Norris and Spieker (1966, p. 22) along the Great Miami River valley in southwest Ohio, suggesting that the preglacial drainage flowed north and was a continuation of the northeast-flowing Kentucky River (fig. 10), as first proposed by Fowke in 1898.

For this recornaissance study, no attempt was made to map in detail the sinuous high-level channel and the associated deposits of the northeast-flowing preglacial Kentucky River. Segments of this channel were recognized by Leverett (1902) but not interpreted by him as belonging to a single sinuous upland stream channel.
Jillson (1946) described an abandoned preglacial channel along the lower course of the present Kentucky River that connects the present valley of the Kentucky River with that of the Ohio. This, the Easterday channel of Jillson, is slightly more than 6 miles long and can be readily followed as a topographic depression from the Kentucky River valley up the valley of Whites Run to a col about a mile northeast of Easterday, Ky. (Vevay South quad., Kentucky-Indiana). From the col, the ancient valley, about half a mile wide and 100 to 200 feet below the upland surface, follows the present valley of Fourmile Creek to join the Ohio River valley near Mile 541 , about 5 river miles above the confluence of the present Kentucky and Ohio Rivers (Carrollton quad., Kentucky-Indiana). In the col is lodged a mass of glacial till; between the col and the present Kentucky River valley are remnants of fluviatile sand and gravel on bedrock benches above the level of the present drainage. Jillson (1946) correlated these deposits with the highlevel channel deposits along the Kentucky River upstream.

The preglacial channel, continuing northeast from the mouth of the Easterday channel, roughly follows the course of the present Ohio River valley to the vicinity of Ghent, near Mile 539 (Vevay South quad., KentuckyIndiana). There it turns in a broad arc to the southeast and follows the valley of the present McCools Creek for about 2.5 miles. Turning to the southeast, up an unnamed tributary valley, the preglacial channel appears

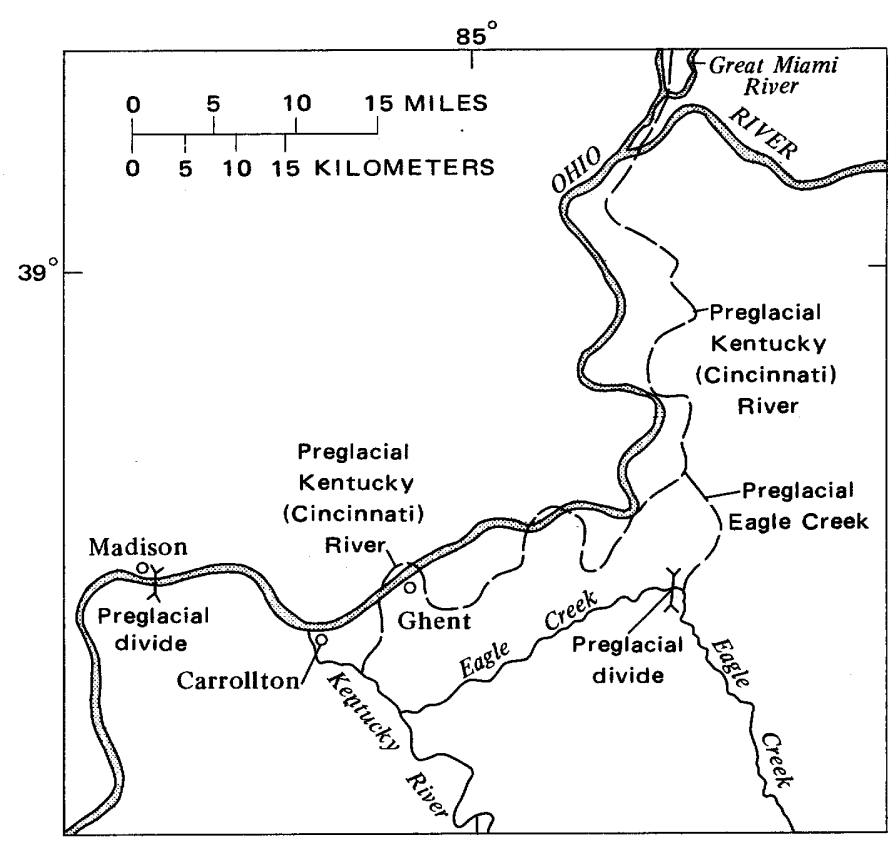

FIGURE 10.-Generalized configuration of the high-level preglacial channel of the northeast-flowing Kentucky River and its relation to the valley of the present southwest-flowing Ohio River. 
to have continued to the valley of Stephens Branch, following it to Stephens Creek (Sanders quad., Kentucky) to rejoin the Ohio River valley near Mile 532, close to the Markland Dam (Florence quad., IndianaKentucky).

The sinuous preglacial channel is believed to have continued to the northeast before swinging again to the southeast in a broad arc to follow up the valley of Dry Creek into the hills back of Warsaw, Ky. (Florence quad., Indiana-Kentucky). Turning to the east, across a low col, the preglacial channel swung northeast along the present valley of Big Sugar Creek and reached the present Ohio River valley again near Mile 523 (Patriot quad., Kentucky-Indiana). Almost immediately the preglacial channel appears to have swung northeast, up the valley of the present Paint Creek, where it is presumed to have joined the preglacial channel of Eagle Creek along the South Fork of the present Mudlick Creek. The combined channels continued in a meandering course to the north in the now dissected hills east of the present Ohio River valley. This course is in large part poorly defined because it has been obscured by Quaternary glacial deposits and partly destroyed by subsequent erosion. The northward direction of the preglacial Eagle Creek valley led Leverett (1902) to suspect that Fowke's suggested northward streamflow might have some validity. Leverett, however, "upon further reflection and reexamination felt that doubt has arisen concerning the validity of this interpretation" (1902, p. 115). As late as 1929 he clung to the belief that "the drainage from the mouth of the Kentucky was down the present course of the Ohio at that (preglacial) time" (1920, p. 25).

The concept that the channel of the preglacial northeast-flowing Kentucky River (fig. 10) was sinuous and high above the present Ohio River level was not recognized by Malott (1922) when he stressed the lack of major bevelling of the upland surface toward the present river valley at Madison, although he reported such bevelling to be present elsewhere along the Ohio, in places both above and below Madison. Furthermore, he (1922) believed that the presumed northeast slope of the bedrock floor of the present Ohio River valley above Madison was important supporting evidence for the Madison divide. This presumed slope was based on insufficient data and was in direct conflict with the southwest slope of the Great Miami bedrock valley, as reported by Fenneman $(1914,1916)$. This conflict Malott attempted to explain away on the basis of possible postglacial uplift. The slope of the present bedrock river valley is, of course, inadmissible as evidence for determining the slope, and thus the flow, of the preglacial (pre-Quaternary) drainageways because the bedrock floor of the present valleys is the result of stream ero- sion of Quaternary rather than pre-Quaternary age. Gradients of the bedrock floors of the preglacial highlevel valleys of Pliocene (Parker) age can be precisely determined only by detailed field studies and regional mapping.

Despite the evidence for a Madison divide proposed by Malott and others, Jillson, following James $(1888,1891)$, Fenneman $(1914,1916)$, and Leverett $(1902,1929)$, rejected the idea of a drainage divide at Madison and postulated that the preglacial Kentucky River followed either the course of the present Ohio River or possibly that of the Muscatatuck River to the southwest. He suggested (Jillson, 1946) that a preglacial Ohio River from the northeast flowed through the Easterday channel to join the Kentucky River in a course to the west. This interpretation was based on the belief that the bedrock floor of the Easterday channel sloped southwest at an average gradient of 1.5 to 2.5 feet per mile. If this unusually high gradient were true, the fluviatile deposits could not be interpreted as being a continuation of the high-level preglacial Irvine deposits of Campbell (1898) along the Kentucky River. To the deposits in the Easterday channel, Jillson assigned a Pliocene age but suggested a change in facies to explain that the deposits were made by a "somewhat longer, and smaller, but contemporaneous (late Pliocene) Ohio River" (Jillson, 1946, p. 31).

It is well known that the course of the preglacial Eagle Creek was, like that of the preglacial Kentucky River, to the northeast, and that the diversion of its lower course to the southwest took place in Quaternary time (Leverett, 1902, 1929; Tight, 1903; Fowke, 1933; Jillson, 1949; Durrell, 1961). Jillson (1949, frontispiece map) indicated that north of the point of its diversion (figs. 3 and 10; Glencoe quad., Kentucky), the preglacial Eagle Creek flowed in a meandering course to join, as a barbed tributary, the west-flowing preglacial Ohio River near the present mouth of Big Bone Creek (Patriot quad., Kentucky-Indiana). This peculiar barbed drainage and its implications are not tenable on the basis of the regional drainage pattern, although they are in agreement with the beliefs of Leverett (1902, 1929).

In 1961, Durrell proposed (fig. 2, p. 49) that this creek, his so-called Eagle River, was a major preglacial stream that followed with reversed flow the Ohio-Great Miami (Cincinnati) River valley to the vicinity of Hamilton, Ohio, where it joined the preglacial Licking River. From this point, drainage may have continued to the north, as shown on his map, as a major tributary to the TeaysMahomet River, or, as he suggests (Durrell, 1961, p. 51), it may have followed an alternative course up the Whitewater valley of southeast Indiana, with a flow reversed from that of the present Whitewater River (fig. 3 ). This alternate route was not possible during 
preglacial time if the interpretations by Wayne (1952) are correct (p. 16).

Field observations by the writer along and adjacent to the Glaciated Ohio River valley and his evaluation of the published studies of others have him led to the conclusion that the preglacial drainage of most of the Bluegrass region was, except for the drainage basins of the preglacial Salt and Muscatatuck Rivers, to the north and was tributary to the preglacial Teays-Mahomet River. The combined drainage basins, excluding the basin of Salt River, provide for a normal rather than a distinctly lopsided shape for the preglacial TeaysMahomet basin in this region (fig. 5). It is no coincidence that the postulated three divides that controlled the drainage of the Bluegrass region in relation to the Teays-Mahomet River are on the erosion-resistant Silurian formations.

Along the flanks of the Cincinnati arch, dips of the erosion-resitant Silurian formations, although gentle, are sufficient to produce a marked topographic expression along the belt of outcrop, thus providing in large part for drainage control. To the north, however, in the region of the postulated drainage divide north and northeast of Dayton, Ohio, the Silurian formations that crop out across the north-plunging crest of the Cincinnati arch are almost horizontal, having dips of nearly 5 feet per mile (Norris and Spieker, 1966). There, the topographic control of the preglacial high-level drainage by cuestas was presumably less effective than where dips are greater. The preglacial Hamilton (Cincinnati) River (fig. 8) could, therefore, flow north to form a major tributary to the main stem of the Teays River northeast of the postulated drainage divide near Dayton. No major high-level preglacial channel across the divide area, underlain by Silurian formations, has yet been identified beneath the thick mantle of glacial deposits. When and if it is identified, it will be narrow and probably steep walled, as suggested by Norris and Spicer (1958).

If there was a major drainage divide at Madison, Ind. and drainage of the preglacial Kentucky and other streams to the east was tributary to the Teays-Mahomet River, then the headwaters of the preglacial Ohio River were west of the Madison divide, and the preglacial Ohio was not a tributary of the Teays-Mahomet River. Therefore, the origin of the Muscatatuck regional slope and its preglacial drainage must be determined in order to establish the position of the headwaters of the preglacial Ohio River.

Formation of the Muscatatuck regional slope in Indiana was described by Malott (1922), with the implication that its extension in northern Kentucky had a similar origin. He recognized that the belts of gently westward dipping and easily eroded Devonian (New
Albany) and Mississippian (Borden Group) shale and siltstone have been almost wholly stripped by westflowing streams from the underlying erosion-resistant limestone of Devonian and Silurian age. Thus, a surface formed that is almost coincident with the dip of bedrock on the west flank of the Cincinnati arch.

Prior to formation of the regional slope in Indiana and Kentucky, preglacial streams-the East Fork of White River and its major tributary, the Muscatatuck River, and the Salt River-headed on the blackslope of the Laughery escarpment. The Muscatatuck regional slope, the Scottsburg lowland, and the Knobstone-Muldraugh Hill escarpment owe their formation to these westflowing streams and their tributaries. Stream erosion during Pliocene (Parker) time progressively removed the incompetent Devonian and Mississippian formations so that the regional slope formed by downdip expansion from east to west. Meanwhile, the Scottsburg lowland and the Knobstone-Muldraugh Hill escarpment were initiated in Indiana and adjacent parts of northern Kentucky. The lowland gradually grew and the escarpment increased in height as the two features retreated westward down the dip of the bedrock.

During the preglacial formation of the Muscatatuck regional slope and the Knobstone-Muldraugh Hill escarpment, the west-flowing preglacial MuscatatuckEast Fork of White River in Indiana and the Salt River in Kentucky cut their valleys into the regional upland west of the escarpment. In preglacial time, therefore, the two major passages through the escarpment, now occupied by the Muscatatuck-East Fork of White River and the Ohio-Salt River, were formed by normal stream erosion as stripping of the regional slope progressed. Such a mode of formation is in agreement with Leverett's (1929) belief that the course of the present Ohio River through the Knobstone-Muldraugh Hill escarpment is preglacial in age, and it is directly opposed to the belief of Gray and Powell (1965, p. 5) that, "Before the Pleistocene Epoch no stream breached the Knobstone Escarpment where the Ohio River now flows $* * *$ "

In Kentucky, the Muscatatuck regional slope is present as a distinct topographic feature for only a few miles south of the Glaciated Ohio River valley. The westward-flowing preglacial Salt River, though superficially similar to the preglacial Muscatatuck River immediately to the north, has had a somewhat different history. East of the Knobstone-Muldraugh Hill escarpment, the Salt River had three main branches: (1) a north branch, which was similar to the Muscatatuck River and which flowed down the regional slope from its headwaters along the back slope of the Laughery escarpment near the Madison divide; (2) a middle branch, the present Salt River; and (3) a south branch, the present 
Rolling Fork, which roughly followed the poorly defined narrow lowland and knobs belt along the southwest side of the Outer Bluegrass region.

Transformation of the north branch of the preglacial Salt River into the present Ohio River as the result of Quaternary glaciation is discussed later as part of the geomorphic history of the Ohio River in Quaternary time. The history of Rolling Fork is not pertinent to the history of the Ohio River and is not discussed. The middle branch, the present Salt River, is, however, of especial interest in that its geomorphic history bears directly on and supports the interpretation of the geomorphic history of both the Ohio and the Kentucky Rivers.

Where the middle branch of the preglacial Salt River flowed across the west flank of the Cincinnati arch, the Muscatatuck regional slope is essentially lacking as a distinct terrain unit. Headwater erosion by Salt River in preglacial time captured the drainage of a north-flowing tributary of the Kentucky River, a piracy noted by Leverett (1929). Drainage of this captured tributary was abruptly diverted to the west at a point approximately 4 miles west of the main stem of the Kentucky River (McBrayer and Salvisa quads., Kentucky). High-level fluviatile deposits, such as those near Alton, Ky. (Lawrenceburg quad., Kentucky; Leverett, 1929), mark the ancient channelway of this tributary of the Kentucky River below the point of capture. Although Leverett (1929) suggested that the high-level deposits were probably Irvine in age, he noted that the stream piracy appeared to have taken place somewhat later than the deposition of the high-level deposits but before the main valley cutting of the Kentucky and Salt Rivers.

During mapping of the nearby Tyrone quadrangle (Cressman, 1964), high-level fluviatile deposits were discovered 225 to 450 feet above the level of the Kentucky River. These have been correlated with the Irvine Formation (Miller, 1925; Jillson, 1943, 1947), but at least two levels of deposits, possibly more, appear to be present. The higher deposits originally described by Campbell (1898), are related to ancient drainageways on the upland, the Lexington surface. The lower deposits are associated with channels cut well below the upland surface-such as the channel at Alton, which, before capture by Salt River, was tributary to the Kentucky River, and with those channels now represented by the abandoned high-level meanders of the Kentucky River. The Wildcat meander described by Jillson (1947) is immediately east of the point of tributary capture by Salt River and follows Gilbert Creek from near its mouth at the Kentucky River (Salvisa quad., Kentucky) to Wildcat Creek valley and Tyrone (Tyrone quad., Kentucky). Although this abandoned channel of the preglacial Kentucky River is slightly lower than the nearby deposits along the old abandoned tributary channel at Alton (Lawrenceburg quad., Kentucky), both channels are preglacial and almost comparable in age, although the piracy by Salt River may have occurred somewhat earlier than the abandonment of Wildcat meander. Both events are assigned, nevertheless, to Pliocene (Parker) time.

The Easterday channel (Jillson, 1946), through which the preglacial Kentucky River flowed to and up the ancient valley now occupied by the Ohio River, is likewise believed to be of Pliocene (Parker) age, correlative with the Wildcat and other abandoned meanders and channels along the Kentucky River. Thus, the preglacial Kentucky River valley, entrenched below the upland surface in Parker time, was graded to the northeast as a tributary of the Teays-Mahomet River, whereas, at the same time, the middle branch of Salt River was graded to the southwest across the Muscatatuck regional slope to the Mississippi embayment.

Today, Salt River at the point where it captured the preglacial Kentucky River tributary has an altitude of nearly 710 feet, whereas the normal pool stage of the Kentucky River, only 4 miles to the east, is at an altitude of 483 feet-a difference of 227 feet. Since stream capture, Salt River has cut down about 100 feet, whereas the nearby Kentucky River has cut to a depth of more than twice that amount. Such an anomaly in river levels and entrenchment can be explained only by the diversion of the Kentucky River drainage in Quaternary time across the Madison divide and into the headwaters of the north branch of Salt River on the Muscatatuck regional slope. As a result of glaciation, to be discussed later, the divide at Madison was breached and obliterated by torrents of glacial melt water in early Quaternary time, so drainage previously tributary to the Teays-Mahomet River was diverted across the divide and into the north branch of Salt River to follow its preglacial course to the Mississippi embayment. The increased volume of water provided static rejuvenation to the new through-flowing river and its major tributary, the Kentucky River, so its erosive downcutting was spectacularly increased. At this time, the main stem of the newly organized river cut into the divide area and into the Muscatatuck regional slope and regraded the preglacial channel of the river above the Madison divide. All cutting was not accomplished at once but took place during the several Quaternary glacial and interglacial times.

Because there was no significant increase in volume of flow of the small preglacial middle and south branches of Salt River, their downcutting was less active. Despite the capture of the drainage of the relatively small tributary to the old Kentucky River, Salt River and Rolling Fork remained only small tributaries to the newly organized great river that flowed west across the 
Madison divide to follow the preglacial channel of the north fork of the preglacial Salt River.

All available evidence indicates a preglacial drainage system east of the Madison divide that was tributary to the major Teays-Mahomet River system. This concept is in accord with the beliefs proposed long ago by Fowke and Tight and elaborated by Malott (1922). Waters of the Eagle Creek and the Manchester, Licking, Whitewater, and Kentucky River basins, confluent in the vicinity of Hamilton, Ohio, are believed, on the basis of field observations and literature review, to have flowed northeast to join the preglacial Teays-Mahomet River as a major tributary (fig. 8). Pregacial drainage on the regional slope west of the Madison divide was gathered into two major west-flowing streams, the combined MuscatatuckEast Fork of White River in Indiana, tributary to the preglacial Wabash River, and the Salt River in Kentucky. These followed courses through the KnobstoneMuldraugh Hill escarpment that were formed in preglacial (Pliocene) time. The present course of the Ohio River entrenched into the Muscatatuck regional slope follows the course of a small preglacial branch of Salt River. Thus, drainage west of the Madison divide belonged to a preglacial basin whose waters were funnelled into the Gulf of Mexico in a course independent of the Teays-Mahomet River. The Madison divide, separating the preglacial Teays-Mahomet basin from the preglacial Salt River basin, was, therefore, of major importance.

Evaluation of the preglacial fluviatile deposits, to which the name Irvine has been loosely attached, indicates that these deposits, although generally similar in character and composition, are found at several different altitudes above the present streams and are of different ages. The Irvine gravel, as originally described (Campbell, 1898) is related to drainage on the upland, Lexington, surface. Somewhat younger deposits are present along abandoned channels and meanders of the major streams that were well entrenched below the upland surface in Pliocene (Parker) time. Deposits at intermediate altitudes and of intermediate age are present but have not been studied.

\section{QUATERNARY HISTORY OF THE GLACIATED OHIO RIVER VALLEY}

In the midcontinent area of the United States, Quaternary time was characterized by successive advances and recessions of glacial ice sheets. Major glaciations, of which four are traditionally recognized-Nebraskan, Kansan, Illinoian, and Wisconsin-were separated by three interglacial intervals-Aftonian, Yarmouth, and Sangamon. Each event left indelible marks of its presence, from which a regional picture of Quaternary events has emerged. Along the Glaciated Ohio River valley, which roughly follows the southern limit of glaciation, the beginning of Quaternary time is marked by the effects of the first invasion by a glacial ice sheet. Until that time, conditions which characterized the late Tertiary (Pliocene) are presumed to have continued essentially undisturbed.

The thesis presented here for the development of an integrated history of Quaternary events in the Glaciated Ohio River valley is based on the belief that each of the four major ice sheets invaded the region from the northeast. Each glacial and each interglacial time played an essential role in river and valley formation, and each has been related to the evolution of the regional terrain. Reconnaissance field studies, together with interpretations and observations of others, have been analyzed. The resultant history here presented agrees in part with, and in part diverges widely from, earlier views.

Since the first geological studies were made along the Ohio River valley and adjacent regions, the general understanding of Quaternary events has progressed rapidly. This understanding has been augmented by information from many local studies, so the interpretations presented here are believed to approach more closely a rational explanation of the developmental history of the Glaciated Ohio River valley and adjacent terrain than the earlier interpretations. Future detailed mapping and field and laboratory studies will, without doubt, clarify and define more precisely the sequence of Quaternary events.

For more than a century, glacial deposits along the Glaciated Ohio River valley have been studied and age interpretations made and later modified (summarized by Ray, 1966); but not until recently have all four major glaciations been identified and reported in this area, through recognition of deposits assigned to the earliest glaciation, the Nebraskan (Leighton and Ray, 1965; Ray, $1965 \mathrm{~b}, \mathrm{c})$. The evolution and modification of the Ohio River valley and the adjacent countryside from preQuaternary time to the present represent a complex sequence of events unrivalled elsewhere along a great river, because the present Ohio River valley and its drainage basin are in large part the result of the Quaternary glaciations. Without the drastic modifications produced by these glaciations, the preglacial TeaysMahomet River system would doubtless still dominate the drainage of the north-central United States.

It has been generally agreed that the first glaciation to invade the area caused disruption of the ancient Teays-Mahomet River system and integration of the several preglacial drainage basins that now constitute a large part of the present Ohio River headwaters. The age of this first glaciation, other than being presumably preIllinoian, has been the subject of speculation for several 
decades. Tight (1903, p. 108) suggested that the glaciation was possibly pre-Kansan in age, although direct evidence was not available to him. Later, Stout, Ver Steeg, and Lamb (1943) suggested that inasmuch as the deep valley entrenchment, the "Deep Stage," of the Ohio and its tributaries was believed to have been accomplished in pre-Illinoian time, the earliest glaciation was probably the one immediately preceding the Illinoian-the Kansan. Stout, Ver Steeg, and Lamb (1943), Thwaites (1946), and Wayne (1956) suggested, however, that the earliest glaciation, the Nebraskan, may have spread into Ohio, Indiana, and northern Kentucky. The first definitive evidence of Nebraskan drift in the area of the Glaciated Ohio River valley was presented by Leighton and Ray in 1965. (See also Ray, 1965 b, c, 1969.)

As early as 1890, Chamberlin (in Wright, 1890) suggested that the deeply weathered and featureless "attenuated drift," beyond the moraines of southwestern Ohio and in northern Kentucky, belonged to one or more drift sheets older than the less weathered deposits now recognized to be of Wisconsin age. Leverett $(1899,1902,1929)$ unfortunately failed to recognize definitely or to establish more than one pre-Wisconsin glaciation in northern Kentucky and hesitantly reached the conclusion that, except for the widespread and isolated erratics, the older drift constituted a single deposit of Illinoian age. Brand (1934, p. 82), after reviewing the possibility of a pre-Illinoian drift, tentatively concluded that "evidence of a pre-Illinoian ice sheet in northern Kentucky is still lacking*** that the glacial material on the uplands south of Cincinnati is water-laid and not ice-laid."

Belief in an Illinoian age for the glacial deposits in northern Kentucky continued (Flint and others, 1945) until the 1950's, when evidence for deposits of Kansan age appeared. Ray (1957) assigned a Kansan age to a glacial till along the Ohio River valley in northern Kentucky that was far more deeply weathered than unquestioned Illinoian till. In southeast Indiana, Kansan drift was reported beneath surficial deposits assigned an Illinoian age (Wayne, 1955, 1956, 1958; Gooding, 1966). In southwest Ohio, Durrell (1961) assigned a Kansan age to surficial drift more deeply weathered and dissected than nearby deposits of undoubted Illinoian age.

Belief in a Kansan rather than an Illinoian age for the deeply weathered surficial drift of northern Kentucky became so well established that by 1959 almost all surficial drift in that area was assigned a Kansan age, but similar deeply weathered surficial drift on the uplands of southwest Indiana, immediately across the Ohio River, continued to be assigned the traditional Illinoian

\footnotetext{
'Shown as Kansan (?) on the Glacial Map of Ohio (Goldthwait and others, 1961). See also Goldthwait and others (1965).
}

age (Flint and others, 1959). In northern Kentucky, the Illinoian drift was almost wholly restricted to a narrow belt along the Ghio River upstream from the Cincinnati area (Flint and others, 1959; Durrell, 1961).

When Leighton and Ray (1965) reported two deeply weathered glacial tills separated by a paleosol in a single well-exposed stratigraphic section on the uplands of northern Kentucky, a few miles southwest of Cincinnati, they assigned to the lower till, which overlay calcareous proglacial sediments and bedrock, a Nebraskan age. To the younger, overlying till they assigned a Kansan age. Thus, three pre-Wisconsin ice sheets of Nebraskan, Kansan, and Illinoian age were recognized as having invaded and profoundly affected the Glaciated Ohio River valley during Quaternary time (Ray, 1965b, c). Although the last glacial ice sheet, the Wisconsin, failed to reach the river valley, it, too, disturbed the river regimen. During the three interglacial and postglacial times, a theoretical equilibrium was reestablished by the river through erosion of the bedrock valleys and their contained glacial deposits.

\section{NEBRASKAN GLACIATION}

The assignment of the oldest glacial deposits in northern Kentucky to a Nebraskan age immediately presents a problem, for no deposits of similar age have been reported from either southwest Ohio or southeast Indiana. There, the oldest reported glacial deposits have been assigned a Kansan age (Wayne, 1955, 1956, 1958; Durrell, 1961; Gooding, 1966). This anomalous situation can be explained by one of three possibilities: (1) glaciers of Nebraskan age did not invade southwest Ohio and southeast Indiana; (2) glacial till of Nebraskan age has been wholly obliterated or removed by subsequent glaciations; or (3) till of Nebraskan age has not been recognized as such, and some or all of the buried tills of southeast Indiana that are reported to be of Kansan age are actually of Nebraskan age, and therefore, the overlying till, long held to be of Illinoian age on the basis of Leverett's studies, may be, like that of Kentucky, in part older and of Kansan age, as implied by Rich (1956). The first possibility is untenable if the identification of till of Nebraskan age in northern Kentucky is valid. The second is unlikely. Field observations tend to confirm the third possibility. The following arguments are based on regional field reconnaissance studies of the glacial deposits and their relation to the terrain. These lead to the belief that the third possibility offers the only rational explanation of the Quaternary glaciations and the regional geomorphic history.

No attempt has been made to map precise boundaries delimiting the glacial drifts of pre-Wisconsin age. The outer limit of glaciation (pl. 1) is of Nebraskan age in Kentucky and follows, with minor modifications, the glacial boundary of Leverett (Jillson, 1929). A generalized boun- 
dary is indicated for the outer margin of the Kansan drift. This boundary is subject to revisions as detailed information becomes available; it is based largely on topographic control and on depth of weathering of the drift deposits. The outer margin of the Illinoian drift in Ohio and Kentucky follows, in large part, the published boundaries of Goldthwait, White, and Forsyth (1961) and Durrell (1961). The ice tongue following the Ohio River valley is discussed later in detail. The boundary of the Illinoian glacial drift in southeast Indiana is based on field reconnaissance and is highly generalized and subject to modification when detailed mapping has provided more information. It is, like the Kansan boundary, based largely on depth of weathering and topographic control. The outer boundary of the Wisconsin drift follows that of Goldthwait, White, and Forsyth (1961) in Ohio and Wayne (1958) in Indiana.

The glaciated terrain mantled by deposits of Nebraskan age (pl. 1) gives no indication of its past glacial history. Whatever configuration the glacial deposits may have had has been obliterated by postdepositional weathering and erosion. Examination of the few exposures of deeply weathered deposits provides the only clue to their glacial origin. In the long time interval since deposition, leaching of the carbonates and decomposition of the small percentage of originally contained crystalline rocks has, where drainage is good, left a surficial mantle of residual silt throughout which small fragments of insoluble vein quartz, quartzite, sandstone, chert, and jasper are scattered at random. In general, weathering has progressed so far on the surficial drifts, whether they are of Nebraskan or Kansan age, that no age differentiation can be made from observations of shallow exposures. Separation of the deposits of Nebraskan and Kansan age is based on stratigraphic succession in the rare exposures, on the topographic position, especially near the outer boundary of the younger Kansan drift, and on the depth of weathering in a few thick drift exposures.

As the ice sheet of Nebraskan age moved from the northeast into southwest Ohio and southeast Indiana to its point of maximum advance in northern Kentucky and southern Indiana, it crossed the preglacial Dearborn upland, the Muscatatuck regional slope, and the Scottsburg lowland. Only major stream valleys, such as the Teays-Mahomet and its larger tributaries, were entrenched well below these surfaces. Deposits referred to the Nebraskan drift indicate that the ice sheet of Nebraskan age was more extensive than that of Kansan age, except in the vicinity of Louisville, $\mathrm{Ky}$., and for a few miles to the north along the base of the KnobstoneMuldraugh Hill escarpment, the west boundary of the Scottsburg lowland. There, the two ice sheets may have been nearly coincident.
In northern Kentucky, postdepositional dissection of the upland surface has left only remnants of the oncecontinuous drift sheet of Nebraskan age on ridge crests and relict upland flats. The outer boundary of the deposits, roughly mapped by Leverett (Jillson, 1929), is largely confined to relict uplands between the present bluffs along the Ohio River valley and to the drainage divide between the short creeks draining directly to the Ohio and those draining to Eagle and Harrods Creeks, a divide roughly parallel to the present river valley (pl. 1 and fig. 3). Only in the vicinity of the mouth of the Kentucky River and in the Louisville area is information so sparse that reconstruction of the general boundary of the Nebraskan drift is uncertain.

Deeply weathered surficial till of Nebraskan age is generally exposed only in shallow roadcuts, where it commonly appears beneath a thin nonpebbly mantle of leached loess of Wisconsin age that may be a few inches to several feet thick. The till is commonly a yellow to red-brown clayey silt containing scattered siliceous pebbles. Subangular chert pebbles may be punky. A diligent search may uncover deeply weathered chert pebbles that retain glacial striations. Where 6 feet or more of till is present, as on Covington Ridge (Bethlehem quad., Indiana-Kentucky) and on the upland south of Milton, Ky. (Madison East quad., KentuckyIndiana), "ghosts" or deeply weathered fragments of crystalline rock may be present at or near the base of the deposit. In general, the long-continued weathering has progressed through the glacial deposits so that all carbonates have been removed by leaching and crystalline rocks have been completely decomposed. Where leaching has attacked the underlying limestone bedrock, the base of the weathered till may be poorly defined and may grade into the red-brown silty clay and angular chert residuum resulting from in situ leaching of bedrock beneath the till. Such deeply weathered deposits have been examined in shallow roadcuts on the uplands of Kentucky in the vicinity of Skylight and Goshen (Owen quad., Kentucky-Indiana), where, as Leverett (1929, p. 51) reported, glacial pebbles are

imbedded in a reddish brown clayey deposit that seems to be mainly derived as a residuary product from the underlying limestone, and only to a subordinate degree supplemented by glacial material. In some of the pebbly clay the color is a more pronounced red than in the outlying districts where it is entirely of residuary character.

Surficial drift in southeast Indiana, in a few poorly exposed sections on the uplands west of the KnobstoneMuldraugh Hill escarpment, was first reported by Thornbury (1932). Examination, by the writer, of the few shallow exposures of glacial drift in this area revealed a deeply weathered, noncalcareous, generally red-brown till of silty clay or clayey silt. Pebbles of weathered siliceous insoluble materials are scattered at random throughout, their abundance increasing with 
depth below the land surface. Deeply weathered and decomposed crystalline rocks were observed only at depth in the thickest sections, such as in the roadcut 1 mile west of New Philadelphia (Little York quad., Indiana) at an altitude of 970 feet.

Although these upland tills have been assigned the traditional Illinoian age by Thornbury (1932) and Wayne (1958), their weathering is far greater than that of unquestioned Illinoian till elsewhere. These upland deposits, referred to in the past as pre-Illinoian in age, may be either of Kansan or Nebraskan age, but depth of weathering of these deposits precludes further age differentiation. For, as can be stressed again, only on the basis of a stratigraphic sequence or differences in topographic position can drifts of more than a single age be recognized.

The upland deposits west of the KnobstoneMuldraugh Hill escarpment are interpreted here to be of Nebraskan age because they are far more deeply weathered than typical Illinoian till and because the Nebraskan ice sheet elsewhere was more widespread than the Kansan ice sheet. The writer believes that here the ice of Nebraskan age was of sufficient thickness and vigor to override the Knobstone-Muldraugh Hill escarpment north of a point about 18 miles north of its presumed southern terminus. South of that point, where the ice may have been thinner near its terminus, the escarpment presented a greater obstacle to the advancing ice sheet, which was unable to override it, and so was deflected along the base of the escarpment toward the preglacial Salt River gorge.

Surficial glacial deposits on the Dearborn upland and Muscatatuck regional slope in Indiana have been thought to be Illinoian in age on the basis of Leverett's (1902) original interpretation. Inasmuch as the Cincinnati soil series is widespread in southeast Indiana, especially on the well-drained uplands believed to be underlain by till of Illinoian age, the concept has evolved that soils of the Cincinnati series are formed on and related only to drift of Illinoian age-a relationship doubted by some soils scientists (Guy D. Smith, oral commun., 1968). When a second till was recognized underlying the surficial till to which an Illinoian age had been assigned and on which soils of the Cincinnati series were present, the underlying till was naturally assigned a Kansan age (Murray, 1955; Gooding, 1966).

Field reconnaissance and an examination of the few exposures of thick sections of glacial drift in southeast Indiana have led the writer to reinterpret the age of the deposits and to conclude that the surficial till is of Kansan rather than Illinoian age and that the older, underlying till is of Nebraskan age. This interpretation is based on several factors, no one in itself definitive: depth of weathering, topographic position, total lack of topographic expression, and relationship of the tills of southeast Indiana to those of northern Kentucky and to the less weathered, younger tills believed to be of Illinoian age within the Ohio River valley (pl. 1).

Till on the Dearborn upland is in general temporarily and poorly exposed in shallow roadcuts that normally consist only of deeply weathered sandy silt containing scattered residual siliceous pebbles. As in Kentucky, the drift has been so deeply weathered in the normal exposure that one cannot distinguish whether it is of Kansan or Nebraskan age. Deeply weathered crystalline pebbles and cobbles are not common except at depth. However, on the basis of the advanced weathering and resemblance to the youngest surficial till on the uplands of Boone County, Ky., the surficial till on the Dearborn upland of southeast Indiana is here interpreted to be in part of Kansan age and in part of Nebraskan age (pl. 1). As in Kentucky, drift on the upland areas where scattered surficial crystalline boulders as much as $\mathbf{2 . 5}$ feet in diameter are common is mapped as Kansan in age. Most of these boulders have been collected and removed from their original sites by local residents as curiosities, for ornamental display, and for driveway markers. A direct relationship between the boulders and the Kansan till cannot be demonstrated on the basis of the present studies, yet such a relationship is suggested, for such boulders do not appear to be related to either the older, Nebraskan, or the younger, Illinoian, driftmantled surfaces of this region.

In 1967 three sections on the Dearborn upland and the Muscatatuck regional slope were visited where tills of two glaciations had been described by Murray (1955) and Gooding (1966). Unfortunately, only one locality was available for suitable examination and checking. Each, however, with the aid of the original descriptions, could be interpreted as having a surficial till older than the Illinoian age suggested.

The first, the Spillway section at Brush Creek Reservoir, Muscatatuck State School (NE1/4 sec. 6, T. 7 N., R. 9 E., Butlerville, quad., Indiana), was no longer well exposed in 1967. The surficial deposits there consist of some 5 feet of silty, sandy, noncalcareous and deeply weathered gumbolike clay underlain by 12 feet of noncalcareous till and 15 feet of calcareous till. Such an advanced profile of weathering is suggestive not of an Illinoian age, as proposed by Murray (1955), but of a preIllinoian age. Furthermore, Murray $(1955$, p. 32$)$ reported that "randomly oriented chunks of darkyellowish-brown noncalcareous till" are incorporated in the calcareous till. This noncalcareous till was presumably derived from an older weathered till, presumably of Kansan age. If, however, the deeply weathered surficial till is of Kansan age, as interpreted here, then the weathered inclusions are older and of 
Nebraskan age, and the older, underlying 1-foot-thick noncalcareous till at the base of the section (Murray, 1955, p. 32) is of Nebraskan rather than Kansas age. Although the reported 1-foot-thick till was so poorly exposed in 1967 that no definite conclusions could be drawn, the writer believes that it can reasonably be assigned a Nebraskan age.

The second section, at the Scott County Stone Co. quarry (NE 1/4 NW1/4 sec. 20, T. 3 N., R. 8 E., Blocher quad., Indiana), had undoubtedly been highly modified since it was first described by Murray (1955, p. 21). Accessible exposures along the quarry face were so badly slumped that the zones and thicknesses reported by Murray had to be used in an attempt to restore the section. Fourteen feet of leached surficial deposits consist of 3 feet of sandy brownish silt underlain by 6 feet of clayey brownish gravel and 5 feet of clayey brown till. Below a depth of nearly 14 feet, Murray $(1955$, p. 21) reported almost 10 feet of oxidized but calcareous till and gravel. Near its base the till is thickly set with tattered and frayed wood fragments. An underlying, noncalcareous till, about 7 feet of which was reported, is compact, dark, reddish to greenish brown, and contains abundant siliceous pebbles, indicating that it was well weathered before the advent of the overlying, younger drift, despite the fact that its profile of weathering appears to have been truncated by the overriding ice sheet. The surficial deposits, because of their depth of weathering, can best be referred to a Kansan rather than an Illinoian age, and the lowest till is therefore of Nebraskan age. Gooding (1966) suggested that the two deeply weathered tills in stratigraphic succession are of Kansan age and represent two glacial advances separated by a nonglacial period. The writer believes, however, that the time intervals represented by weathering in the sections described by Murray (1955) are greater than the intraglacial intervals reported by Gooding.

The third section, described by Gooding (1966) at Osgood (SW. cor. sec. 7, T. 8 N., R. 12 E., Pierceville quad., Indiana), was exposed during road construction in 1959 . By 1967 it was so overgrown and washed that it would have been difficult to interpret had it not been for the published section (Gooding, 1966, p. 427). The basal 10 feet, resting on Ordovician bedrock, was covered when examined by Gooding and in 1967. The top of the 65 -foot section of glacial drift is an eroded ridge crest 20 feet or more below the level of the nearby rolling upland, indicating the magnitude of post-depositional erosion. Although thickness of drift on the upland is not known, the exposed Osgood section may occupy a preglacial valley cut into the bedrock upland by preglacial Laughery Creek or one of its tributaries. The lowest exposed 10 feet of the section consists of laminated calcareous clay interpreted by Gooding $(1966$, p. 429$)$ to be a lacustrine deposit that "may have been deposited in ponded waters of a tributary of the north-flowing Teays-age Eagle River, which existed along the IndianaOhio State line west of Cincinnati (Durrell, 1961, p. 49, fig. 2) when Kansan ice advanced into the area." The interpretation presented here is that the original ponding of drainage was by the first glaciation; the clay is therefore assigned a Nebraskan rather than Kansan age. In general, the clay appears to be similar to the proglacial lacustrine clay of Nebraskan age reported in the Pleasant Valley section by Leighton and Ray (1965).

The Osgood section is separable into an upper 40-foot drift and a lower 25-foot drift. The upper drift, leached only to a depth of 6 feet or so, has been, because of its topographic position on a narrow ridge crest, so eroded in postdepositional time that the amount of weathering and the time involved cannot be estimated. At the bottom of the thin leached zone is a concentration of calcareous concretions (Gooding, 1966). These concretions are similar in stratigraphic position to those noted by Leverett $(1902,1929)$ in the surficial drift deposits at Lookout Heights, Boone County, Ky., to which he assigned an Illinoian age. This drift, however, is now believed to be of Kansan age (p. 26). The lower drift of the Osgood section is leached to a depth of only 7 feet, leading one to suspect either that its profile of weathering has been truncated or that perhaps leaching has been inhibited because the drift was deposited in a preglacial channel in which drainage was poor. On the basis of their regional relations and characteristics, the two drifts are here interpreted to be of Nebraskan and Kansan age rather than Kansan and Illinoian age, as held by Gooding.

The Dabney section, 1.4 miles north of U.S. Highway 50 along the east side of Michigan Road (SW1/4 sec. 31, T. 8 N., R. 11 E., Versailles quad., Indiana), is a new section. It consists of two thin till sheets exposed in a shallow roadcut below an almost flat upland surface having an altitude of nearly 950 feet. Here, a lower, dark-brown compact calcareous but oxidized and crumbly till as much as 4 feet thick contains much chert and crystalline rock. Its highly irregular upper surface indicates an unconformity, presumably the result of proglacial stream erosion before deposition of the overlying till. Above this, 2 to 6 inches of stratified calcareous pinkish to purplish silt and sand is present below a 1-inch-thick plate of silt and pebbles cemented by secondary calcium carbonate, presumably derived from leaching of the overlying till. This plate is interpreted as the basal part of the upper till, which consists of nearly 8 feet of clayey till crisscrossed by drying cracks. The upper 6 feet or so of the section is covered and unavailable for study. Of special interest is a large 
buried and deeply rotted coarse crystalline boulder about 2.5 feet in diameter, similar in size to the surficial boulders found elsewhere on drift assigned a Kansan age. As in the Osgood section, the basal concentration of calcium carbonate appears to be characteristic of drift of Kansan age. Although both the base and top of the section are concealed and unavailable for study, this relatively shallow section is interpreted, on the basis of the sum total of its characteristics, to be a truncated remnant of a lower till of Nebraskan age overlain by proglacial deposits and till of Kansan age.

A shallow 4-foot exposure in a road corner near Butter Falls (NW. cor. SW1/4 sec. 13, T. 3 N., R. 9 E., Madison West quad., Indiana-Kentucky), about 20 feet below the local upland surface of the Muscatatuck regional slope, consists of deeply weathered crystalline "ghost" pebbles in a bright-red to red-brown silty clay matrix containing scattered chert pebbles. The clayey matrix possibly is in part derived from glacial material and in part from weathering of the underlying limestone bedrock on which the till rests. This deeply decomposed till, like that in the vicinity of Goshen and Skylight, Ky. (p. 23), is probably of Nebraskan age. In marked contrast is the brown silty till containing randomly distributed insoluble siliceous pebbles that crops out 2.5 miles north along State Route 256, just east of the valley of an unnamed fork of Ramsey Creek. This silttil is similar to many other scattered surficial outcrops in southeast Indiana and is here interpreted, on a regional basis, to be of Kansan age.

The area most critical for verification of two preIllinoian glaciations is the relatively undissected upland in northern Kentucky, south and southwest of Cincinnati, especially west of the Licking River in Kenton and Boone Counties (pl. 1). Because of rapid urbanization there, most exposures are only temporarily available for study, and the widespread removal of surficial deposits has not only modified the terrain but destroyed valuable evidence for determination of its glacial history. Here, where the outer margin of the ice sheet or sheets was presumably thin, possibly fluctuating, and highly crenulated, glacial deposits of differing origins appear to be complexly intermingled. Evidence for preglacial and glacial drainageways abounds on the upland surface, now dissected by headwater erosion of creeks draining to the Ohio and Licking Rivers (Covington and Burlington quads., Kentucky-Ohio; Lawrenceburg quad., Kentucky-Indiana-Ohio). In places, glacial outwash overlies till; in others, the outwash is overlain by till. Brand (1934) reported lenses of till incorporated in outwash deposits.

In the vicinity of Lookout Heights (Covington quad., Kentucky-Ohio), Leverett (1929, p. 12-13) observed deposits of a "fine grade of molding sand ${ }^{* * *}$ covered by a glacial deposit, that shows a much higher degree of weathering than the Illinoian till of that region," for the deposit has no limestone, "yet the chert which accompanies the limestone is abundant, and it probably was originally thickly set with limestone pebbles." He reported, furthermore, that near the base of the leached sand, large secondary calcareous nodules were present, suggesting that calcite had been leached from the overlying glacial drift and redeposited at depth. On the basis of the available exposures, Leverett $(1929$, p. 32$)$ was led to conclude that the glacial deposit overlying the sand was possibly of pre-Illinoian (Jerseyan?) age. Excellent exposures confirming Leverett's observations were temporarily available for study in 1961 during grading operations for a subdivision in Lookout Heights, about 0.4 mile west of St. Agnes Church. No exposures were available to Leverett to indicate that the "molding sand" was underlain by glacial till.

Evidence for an underlying till was seen in 1961, when a till was exposed in an excavation during building construction adjacent to Interstate Highway 75, south of the Lookout House in Lookout Heights, about 0.6 mile southeast of the exposures similar to those described by Leverett west of St. Agnes Church. Here, a blue-gray compact calcareous till containing limestone and scattered crystalline rock pebbles was present at an altitude of approximately 800 feet, almost 50 feet below the crest of nearby exposures of deeply weathered silty sand, immediately east of the Lookout House. Thus, in a restricted area, a compact calcareous glacial till, whose deeply weathered upper surface is not exposed, is overlain by a deeply weathered silty sand, which is in turn overlain by a surficial till more deeply weathered than till of Illinoian age. Inasmuch as the weathering of the basal and the surficial drifts is greater than that on deposits assigned an Illinoian age, deposits of two preIllinoian glaciations are therefore suggested, but not proven, for the entire section may be the product of icemarginal deposition during a single glaciation, generally referred to as Kansan in northern Kentucky, a theory favored by Schaber (1962).

Further evidence for two pre-Illinoian glaciations in northern Kentucky is based on an interpretation of the geologic history of closely spaced roadside exposures near the intersection of State Roads 236 and 1334, at the northeast corner of the Greater Cincinnati Airport (Burlington quad., Kentucky-Ohio), about 7.5 miles west of Lookout Heights and 1.7 miles southwest of the Ohio River valley in northeast Boone County, Ky. (pl. 1 and fig. 11). Section A is on the northeast side of State Road 236, about 1,000 feet northwest of the intersection with State Road 1334. Sections B and C are in a continuous exposure along the southeast side of State Road 1334, starting about 150 feet northeast of the intersection, where the state road descends sharply into the valley of Elijahs Creek. 


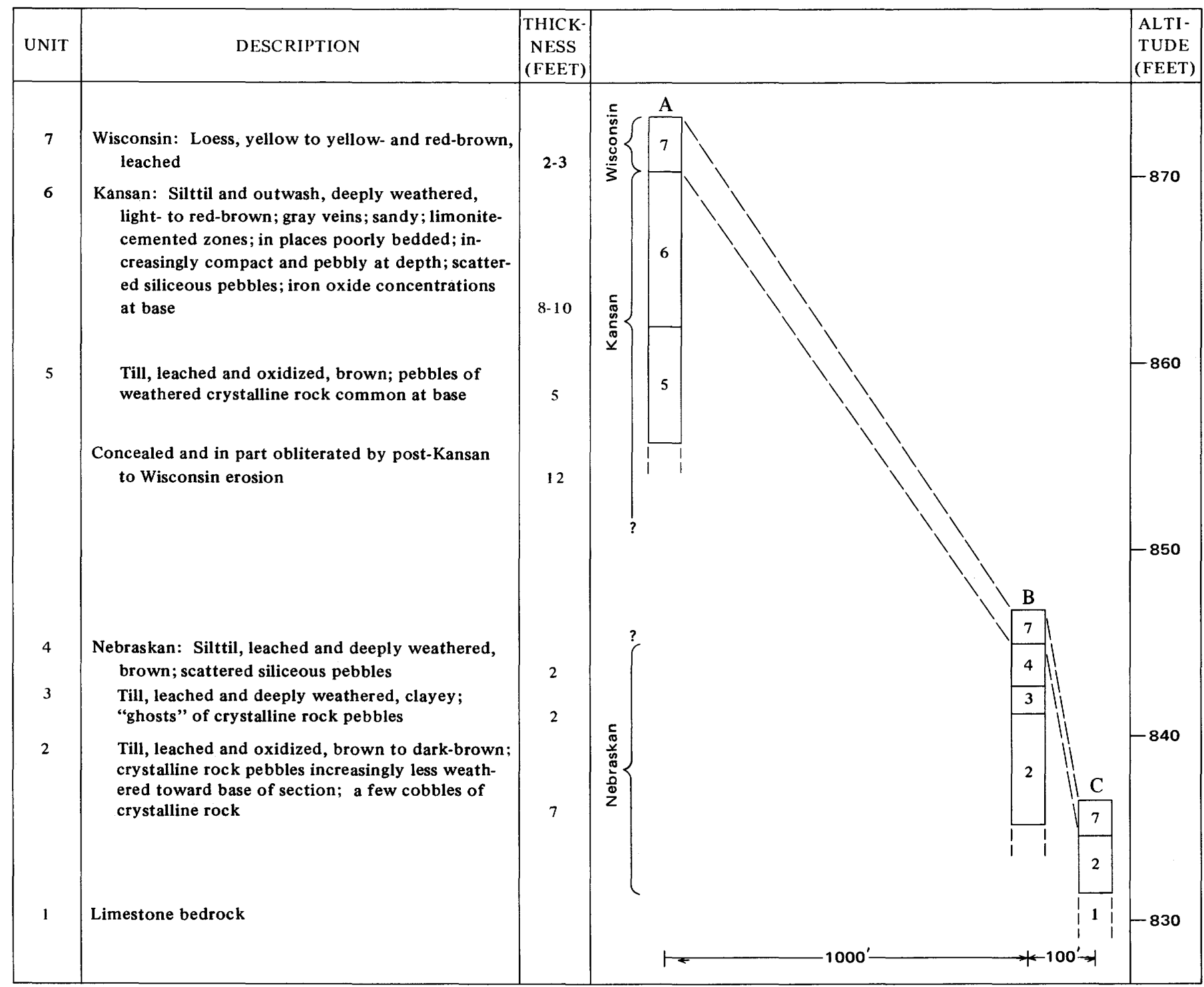

Figure 11.-Composite stratigraphic section at the intersection of State Roads 236 and 1334 at the northeast corner of the Greater Cincinnati Airport, Burlington quadrangle, Kentucky-Ohio. Modified from Durrell, 1965.

In the vicinity of these sections, called the Airport sections, a dissected and gently rolling upland at an altitude of 900 to 930 feet is underlain by deeply weathered silty sand and glacial till mantled by a few inches of Wisconsin loess. This widespread upland is interpreted as an outwash plain of Kansan age probably formed along the waning irregular margin of the ice sheet. Lacustrine deposits may have been intercalated in places with the outwash deposits, but unfortunately, grading during construction of the airport destroyed much of the original upland surface and obliterated the glacial deposits.

The Airport sections (fig. 11), because of their significance in determining the Quaternary history, were carefully examined during field studies. They were also studied and briefly described by Durrell (1965), who interpreted them as representing a single deeply weathered till of Kansan age. However, this writer believes that they indicate glacial deposits of Nebraskan and Kansan ages, separated by an interglacial interval of weathering and erosion, the Aftonian.

The Quaternary history of the Airport sections, as interpreted here, starts with the invasion of the area by the first of two pre-Illinoian ice sheets, the Nebraskan. Glacial till of Nebraskan age was deposited on the preglacial bedrock uplands of low relief (fig. 11, secs. B and C). This first till, of which about 11 feet remain, is believed to have been deeply weathered and leached of its primary carbonates prior to deposition of the overlying till (fig. 11, sec. A), here assigned a Kansan age. The 
lower part of the Nebraskan till in section B contains weathered crystalline pebbles and cobbles with thick weathering rinds. Progressively higher in the section, the crystalline rocks are more and more deeply weathered and appear as "ghosts" before their final disappearance near the top, where only insoluble siliceous pebbles remain scattered in the silttil near the top of the glacial drift (sec. B). Thickness of the original, highly calcareous unweathered till before leaching is not known, but, on the basis of a presumed high percentage of limestone rocks and calcareous matrix, it may have been several times the thickness of the present deeply weathered residuum.

After the Aftonian period of weathering, the second ice sheet, of Kansan age, invaded the uplands. Deposition of till was followed by deposition of a widespread deltaic outwash plain in front of the irregular, melting, waning glacier. Till, outwash, and, perhaps, lacustrine deposits are believed to have been intermingled over a widespread area of the uplands.

Kansan glacial time was followed by a long and presumably uninterrupted period of weathering and erosion that continued until deposition of a thin blanket of loess of Wisonsin age over the Nebraskan and Kansan deposits. During this time, the surficial deposits of Kansan age were also deeply weathered, and creeks, such as Elijahs Creek, eroded headward into the upland area. The outwash deposits were dissected and stripped; in places the underlying till was removed or truncated. The Airport sections were probably stripped by erosion during this time. Section A, which is in a roadcut through a ridge between small steeply graded gullies along Elijahs Creek, is well below the level of the adjacent outwash plain. Sections B and C, also exposed along a gully in the west valley wall of Elijahs Creek, have been more deeply eroded and stripped of Kansan drift. Such a history suggests that the Airport sections provide a sequence of two pre-Illinoian glacial deposits on remnants of the preglacial upland. Although not exposed in a single stratigraphic sequence, the closely spaced sections indicate a composite stratigraphic succession of two deeply weathered pre-Illinoian glacial tills, rather than a single till whose surface irregularities may have been preserved since its original deposition in Kansan time, as implied by Durrell (1965).

Leighton and Ray (1965) described a section on the uplands of northern Kentucky in which two pre-Illinoian tills are present in a single stratigraphic succession. The older till, on the basis of its topographic position and its relation to the regional distribution of younger glacial deposits and to the geomorphic evolution of the region, is assigned a Nebraskan age, and the overlying till, a Kansan age. This, the Pleasant Valley section, is about 5.5 miles southwest of the Airport sections. It is a road- cut, fresh in 1963, along Pleasant Valley Road 1.8 miles northwest of its junction with U.S. Highway 42 at Sugartit (Union quad., Kentucky). In this vicinity the gently rolling upland has been dissected by a network of small shallow creek valleys, and surface features give no indication that the country has been glaciated.

Pleasant Valley section

[Composite section modified from Leighton and Ray (1965)]

Wisconsin

Loess, leached, yellow to yellow-brown $\ldots$

Kansan:

Silttil, leached and deeply weathered; thin gray soil zone at

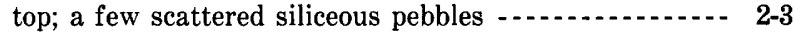

Gumbotil, dark-gray, clayey, tenacious; small siliceous pebbles -........... 2-4

Till, leached and oxidized; iron oxide concentrations; pebbles increasingly larger and less altered with depth ....... 1-3

Till, calcareous and oxidized; a few crystalline rock pebbles $2-3$ Aftonian:

Paleosol, black; erosional remnant .................... 0-1 Nebraskan:

Gumbotil, brown-gray to gray, clayey, tenacious; shrinkage cracks prominent when dry; small siliceous pebbles ---- 3

Till, leached and oxidized; concentrations of iron oxides; pebbles increasingly larger at depth ............. 2-3

Till, calcareous and unoxidized, blue-gray, compact; fine silty clay matrix containing minute woody fragments -..... 3-4

Silt, sand, and clay of proglacial origin, calcareous -...- 8 Bedrock.

After deposition of the oldest till, the Nebraskan, which in the Pleasant Valley section overlies outwash, drainage of the upland surface was poorly organized. After the waning of the ice sheet, during Aftonian interglacial time, deep weathering reduced the volume of the till through leaching of its carbonate content, and a clayey gumbotil was produced in the upper part of the deposit where the crystalline rocks had been obliterated and only scattered siliceous insoluble pebbles remained. Meanwhile the master stream of the region, the newly organized Ohio, entrenched its valley into the driftcovered upland surface. Bedrock benches indicative of this stage of landscape dissection were noted by Brand (1934) and Durrell (1961), who did not definitely relate them to the glacial history. Where short tributary streams eroded headward from the deepened major valley into the poorly drained upland, drainage conditions were improved. At the Pleasant Valley section, remote from the expanding drainage net, the till of Nebraskan age remained little eroded and poorly drained, so it was deeply weathered in place, as attested by the presence of gumbotil and the remnants of thin humic soil.

The succeeding invasion of the Kansan ice sheet into northern Kentucky spread a deposit of till across the upland; this till was areally less extensive than that of Nebraskan age. In places, drift was deposited in valleys 
cut below the upland during Aftonian time. At the Pleasant Valley section, Kansan till was deposited on the deeply weathered till of Nebraskan age. The remnant of humic soil indicates that the Nebraskan till was not truncated there by the overriding Kansan ice.

Further confirmatory evidence for a sequence of two glacial tills of Nebraskan and Kansan age is provided by an interrupted section one-half mile southeast of the Pleasant Valley section along Pleasant Valley Road. There, 5 feet of deeply weathered till is exposed, and, at a slightly lower altitude about 200 feet farther along the road, 4 feet of calcareous till containing limestone pebbles overlies noncalcareous gumbotil, of which only 1 foot is exposed. Elsewhere, roadcuts in the vicinity are shallow and in general reveal only a deeply weathered surficial silty till, which, on the basis of the Pleasant Valley section, is believed to be of Kansan age.

Deeply weathered exposures in the vicinity of Lookout Heights, those adjacent to the Greater Cincinnati Airport, and those on Pleasant Valley Road lead inescapably to the conclusion that the uplands of this part of northern Kentucky have been invaded by two ice sheets of pre-Illinoian age. Farther west, only a single deeply weathered drift appears to be present, and its position on the uplands, above the level of a younger drift, leads to the conclusion that it is of Nebraskan age and that the Nebraskan ice sheet was more extensive than that of any succeeding glaciation.

The invasion of the relatively undissected upland of southeast Indiana, of southwest and perhaps southeast Ohio (Ray, 1969), and of northern Kentucky by an ice sheet of Nebraskan age is not only of local but of regional significance, for it implies that the ice lobe of the first glaciation in the east-central United States came from the northeast, from the so-called Labradorian dispersal center east of Hudson Bay. Such an ice invasion is presumed to have been penecontemporaneous with the first ice sheet, the Nebraskan, that invaded the west-central United States from the so-called Keewatin center west of Hudson Bay. That only the area west of Hudson Bay and not that to the east should have been a dispersal center for glacial ice of Nebraskan age is not realistic. Furthermore, the relationship of Nebraskan deposits in the area of the Glaciated Ohio River valley to the regional geomorphic history is apparently similar to the relationship of the Nebraskan deposits in northeast Iowa to the regional geomorphic history there (Trowbridge, 1966).

\section{DRAINAGE MODIFICATIONS RESULTING FROM THE NEBRASKAN GLACIATION}

With a few exceptions, most studies concerned with the drainage modifications and development of the present upper and Glaciated Ohio River valley have followed the basic tenets so well set forth in the classic study by Tight (1903) - that the drainage pattern of today evolved largely as the result of glacially induced modifications of preglacial drainage systems. These modifications for the most part resulted from proglacial blockage of drainage channels by the advancing ice sheet; this caused ponding of drainage until the divides between basins were overtopped, and the torrential flow formed new interbasin channels. Elsewhere, preglacial drainage channels may have been overwhelmed by the glacier and permanently destroyed. Most agree that it was the first glacial invasion of the region that most radically modified and integrated the preglacial drainage of the upper Ohio River valley. Although the age of this first glaciation has, until recently, been in doubt, the basic principles marshalled to explain the drainage modifications have remained largely unchanged since the studies by Chamberlin and Leverett $(1894 a, b)$.

Through recognition of a Nebraskan age for the oldest glaciation in the Ohio River basin, some earlier uncertainties have been removed, and a more rational Quaternary chronology is seemingly possible. However, many unsolved problems remain (Ray, 1969) that can be answered only by detailed field and laboratory studies. Much of the evidence for a detailed regional chronology of the drainage modifications resulting from the glaciation of Nebraskan age is fragmentary and obscure, for, except along the Glaciated Ohio River valley, the extent of the Nebraskan ice sheet has not been determined.

Inasmuch as the shape and relative rate of advance of the component parts of the ice sheet of Nebraskan age cannot be reconstructed at present, the detailed history of drainage changes occasioned by its advance is in large part speculative. Yet, a working hypothesis is necessary and is presented here to explain those features now observable and to account for the suspected sequence of events.

Because the position or maximum advance of only a small sector of the margin of the ice sheet can be reasonably determined along the Glaciated Ohio River valley, one cannot state dogmatically whether this sector was the terminus of a major advancing ice lobe or merely the lateral margin of a lobe whose main axis presumably lay to the north and west. The writer suspects, however, that the Nebraskan ice sheet in northern Kentucky was the lateral margin of an ice sheet that moved from the northeast into the northcentral United States. Furthermore, one cannot assume, for even this small sector of the ice margin, that the position of maximum advancement of the ice was reached simultaneously at all points.

Lack of information concerning the rate and position of the advancing ice front at any given time precludes 
determination of the precise sequence of stream blockage, ponding, or the overwhelming of preglacial drainage basins in any but the most general terms. The sequence of events outlined here is presented, therefore, with full knowledge of its speculative qualities and with the hope that future studies may indicate either its basic validity or its fallacies.

\section{DRAINAGE MODIFICATIONS ABOVE THE MANCHESTER DIVIDE}

The drainage modifications that produced the present Ohio River above the Manchester divide have been discussed by many (Chamberlin and Leverett, 1894a, b; Leverett, 1902; Tight, 1903; Happ, 1934; Stout and others, 1943). It is generally believed that in preglacial time along the course of the present Ohio River above the Manchester divide in southern Ohio, there were two major drainage systems separated by a divide at New Martinsville, W. Va. (fig. 5). Regional drainage between New Martinsville and Pittsburgh was to the north through preglacial stream channels that presumably followed the Lake Erie-St. Lawrence lowland to the Atlantic Ocean. Drainage of the present Ohio River valley between the New Martinsville and Manchester divides was, on the other hand, to the west and south to the Gulf of Mexico through the Teays-Mahomet River. The divide at New Martinsville was, therefore, of major regional importance, whereas that at Manchester was less important in that it separated only the drainage basin of the main Teays-Mahomet from that of one of its larger tributaries.

It is generally conceded that the ice sheet of Nebraskan age permanently disrupted drainage both to the north and to the west; this resulted in a complex series of stream diversions that in part involved reversals in direction of flow. As the ice sheet moved into the lower latitudes from the northeast, north-flowing streams draining through the Lake Erie-St. Lawrence lowland were the first to be blocked and impounded. As the ice advanced and the impounding continued, water levels increased in the drainage basins, and widespread fingerlike lakes formed. These proglacial lakes may have been interconnected by the overtopping of many minor cols between tributary streams. The impounded normal drainage, greatly augmented by melt-water torrents, eventually rose to overtop and breach the lowest col along the divide at New Martinsville, which separated the headwaters of the impounded north-flowing rivers from the west-flowing Teays-Mahomet drainage. Eventually, the divide was thoroughly breached and permanently destroyed. As a result, the preglacial northward flow of streams above the divide was reversed to the south, and the first major transforma- tion in the formation of the Ohio River basin of today was accomplished.

The precise time at which the Manchester divide was overtopped relative to the position of the advancing ice sheet of Nebraskan age is conjectural. The main stem of the Teays-Mahomet drainage system must have been overwhelmed at some point by the glacier in order to be impounded above the Manchester divide (fig. 5) and eventually overtop the divide. Whether the waters of the north-flowing Cincinnati River, tributary to the TeaysMahomet, were impounded by the advancing ice sheet in southwest Ohio before or after the breaching of the Manchester divide is not known. If the waters of the Manchester River, augmented by the torrential waters flowing across the breached Manchester divide, had joined those of the Cincinnati River, and if this combined Manchester-Cincinnati River had existed for any extended period of time as a major tributary to the Teays-Mahomet (fig. 5), one would suspect that a valley eroded in the area of outcrop of Silurian formations in the vicinity of Dayton, Ohio, would be a conspicuous bedrock feature. Because no such valley is known, the torrents flowing to the north to join the Teays-Mahomet drainage probably did not exist for long and the ice sheet of Nebraskan age must have overwhelmed the lower course of the Cincinnati River almost simultaneously with the blocking of the main Teays drainage, or shortly thereafter. Therefore, not long after the breaching of the Manchester divide, all drainage to the main TeaysMahomet River was impounded in high-level digitate lakes in the preglacial basins of the Cincinnati River and its tributaries, such as the Manchester, Licking, and Kentucky Rivers.

On the basis of present information, one can accept only the belief that when the advance of the Nebraskan ice sheet blocked the main stem of the Teays-Mahomet River, presumably in central Ohio, its drainage was impounded, and the ice-dammed river rose to overtop and breach the Manchester divide. If, however, the Manchester divide was later overridden by the Nebraskan ice sheet at the time of its maximum advance, a possibility suggested by Ray (1969), the divide was for a brief time inoperable, and a more complex history of drainage modifications is required. Presumably, whatever drainage diversions may have been caused by the possible overriding of the Manchester divide, the resulting channelways were not permanently established. After the waning of this possible ice advance, the channel across the Manchester divide was reoccupied, and the drainage reestablished to the west has continued to the present. Later dissection of the preglacial upland surface, together with the deep weathering and erosion of surficial deposits, may have 
so obscured the sequence of events that the history of drainage modifications will be difficult, perhaps impossible, to verify completely. Whatever the sequence of events, the writer suggests that as a result of the first glaciation, the Nebraskan, drainage above the Manchester divide was initially integrated into a single basin and was later forced to breach the divide permanently and flow west along the preglacial Manchester River.

Some have suggested that not all drainage diversions above the Manchester divide resulted from glacial disruption of the preglacial drainage net. Rhodehamel and Carlston (1963) suggested that the Teays River valley in West Virginia "*** was abandoned in late Tertiary or early Pleistocene time by normal stream capture processes***” (p. 251). They stressed the deeply weathered alluvium on the bedrock valley floor and proposed for it a late Tertiary (?) or early Quaternary age, inasmuch as it consists largely of siliceous insoluble materials derived from within the preglacial drainage basin. They implied that this alluvium is essentially preglacial bedload. Furthermore, they noted (p. 260-261) an illuvial "pan" at or near the base of the alluvium in places and interpreted it as a weathering product that has "migrated down" through the coarse siliceous insoluble materials. The writer suggests that the materials derived from within the basin are the ancient bedload whose transportation downstream was halted when the river became ice dammed and its drainage impounded, and that into the impounded waters, finegrained sediments, largely silt and clay, probably calcareous, were introduced by proglacial melt waters. When the Nebraskan ice sheet waned and the drainage had been rearranged, alluvium within the valley was subjected to subaerial weathering and erosion, and a mature soil profile formed during Aftonian interglacial time. When the valley was again flooded by impounded waters, presumably as a result of the Kansan ice sheet advance, the deeply weathered alluvium was mantled by a younger lacustrine deposit, the Minford Silt of Stout and Schaaf (1931).

In summary, the interpretations briefly presented here follow in large part the earlier beliefs that the integration of drainage above the Manchester divide and the consequent diversion of torrential drainage across the divide to the west along the course of the preglacial Manchester River resulted from an invasion of the preglacial drainage basins by an ice sheet of Nebraskan age. Details, especially the timing of drainage modifications during the ice advance, are obscure. Furthermore, it has been suggested that during the maximum advance of the ice sheet, the Manchester divide itself may have been briefly ice covered and the resulting drainage complicated in ways not yet understood.

\section{DRAINAGE DEVELOPMENT BETWEEN THE MANCHESTER} DIVIDE AND THE LOUISVILLE AREA

When the north-flowing Cincinnati River and the main Teays-Mahomet River had been impounded by the advancing Nebraskan ice sheet, melt waters issuing from the ice sheet from northwest Pennsylvania to southeast Indiana, together with drainage from the unglaciated parts of the drainage basins, were gathered into a series of proglacial lakes whose height was regulated by the altitude of the lips of the cols along the interbasin divides. When cols between the basins were breached, the impounded torrents, flowing from one basin to a lower basin, quickly eroded the divides so lake levels were maintained only temporarily at their maximum heights. The brevity of sustained lake levels may explain the lack of evidence for abandoned shorelines and beaches at high levels in northern Kentucky.

At the time of the greatest extent of the Nebraskan ice sheet, a proglacial lake may have existed between the Manchester and Madison divides, if only temporarily, as a series of connected lakes occupying the impounded basins of the major stream valleys and their tributaries. Presumably the impounded lake waters rose to the height of a col in the Madison divide, possibly somewhat below an altitude of 850 feet, and overtopping the col allowed escape to the west through the Salt River drainage to the Mississippi embayment-the drainageway now occupied by the Ohio River. Thus, for the first time, Salt River was a drainageway of major regional importance, serving as a sluiceway for glacial melt water and for drainage from a greatly expanded basin that had belonged in part to the preglacial TeaysMahomet River system.

As the ice sheet continued to advance, the confluence of the stream south of Hamilton, Ohio, was overridden, and the direct connection between drainage from the east and the west was blocked (fig. 6). To the east the ponded drainage of the Manchester and Licking Rivers rose until, by a series of diversions in northern Kentucky from one impounded proglacial basin to another, drainage presumably reached the ponded. Kentucky River basin, thereby gaining access to the westward drainage across the Madison divide. The drainageways connecting these basins have not been determined in the field, although many stream-modified high-level cols and channels containing fluviatile deposits are well known on the uplands (Leverett, 1902, 1929; Durrell, 1961). These now-abandoned drainageways are intermediate in altitude between the preglacial bedrock valley bottoms of Parker (Pliocene) age and the broad rolling uplands of the Lexington plain. High-level channels with deposits of sand, gravel, and laminated clay, not to be confused 
with deposits of the Irvine Formation of preglacial age, are common in northern Kentucky immediately beyond the limits of glaciation (Durrell, 1961). In many areas, subsequent erosion and weathering may have modified or destroyed so much of the evidence that the complete and complex picture of the maze of interbasin channels and the sequence of drainage changes may never be precisely determined.

During final advance of the ice sheet along a broad front in the Cincinnati to Louisville area (pl. 1), the glacier reached its position of maximum extension in northern Kentucky. Here it crossed and obliterated the newly organized reversed drainage to the west along the preglacial Kentucky River valley and its tributary Eagle Creek valley, the newly breached Madison divide, and the drainage channel west from the Madison divide along the north branch of Salt River. Although this position is important in the drainage history, it was not long maintained and may have been related to a local ice surge. Because the extended glacier was too feeble to continue its forward movement, it is presumed to have been thin, possibly fluctuating locally, highly crenulated along the margin, and rapidly melting. Little coarse or crystalline debris appears to have been carried by the frontal ice in its terminal position, so melt water, laden largely with sand, silt, and clay, either was discharged along the ice front into dammed stream valleys and shallow proglacial upland lakes or was thinly spread across the upland surface as widespread outwash plains, as in northern Boone and Kenton Counties, Ky. (Luft, 1969; Swadley, 1969a, b).

As soon as the advancing ice sheet overwhelmed the newly organized channel between the Cincinnati and Louisville regions and the breached Madison divide, drainage was totally disrupted, and a new bypass channel became an immediate necessity. As a result, two independent west-draining channels formed along the ice margin for temporary relief of the blocked drainage. The first, east of the Madison divide, followed in general the present lower course of Eagle Creek, now tributary to the Kentucky River (fig. 3). The second, west of the Madison divide, followed a course similar to that of the present Harrods Creek, now tributary to the Ohio River immediately above Louisville, Ky. (fig. 3). Each bypass channel temporarily directed the torrential drainage to the west along routes that converged at the head of the preglacial Salt River gorge through the Knobstone-Muldraugh Hill escarpment. From there, drainage followed the preglacial channel of Salt River to the Mississippi embayment.

The bypass course east of the Madison divide has long attracted attention because of the sharp, right-angle bend in the course of Eagle Creek about 4 miles east of Glencoe, Ky. (Elliston and Glencoe quads., Kentucky).
At this bend, the north-flowing Eagle Creek, following in general its preglacial channel, turns abruptly southwest to follow a course that is only a short distance south of and more or less parallel to the margin of the drift of Nebraskan age (pl. 1). This striking change in direction of flow, noted by Leverett (1902), Tight (1903), Fowke (1933), Jillson (1949), and Durrell (1961), has generally been attributed to stream capture through piracy. Recent detailed mapping has revealed, through relict fluviatile deposits, a preglacial high-level channel leading from the presumed elbow of capture to the northeast (W C Swadley, oral commun., 1969). This confirms the belief that the preglacial Eagle Creek was tributary to the northeast-flowing Kentucky River that was, in turn, tributary to the Teays-Mahomet River through the Cincinnati (north-flowing Hamilton) River (figs. 8 and 10).

Although field data are few, the spectacular diversion of Eagle Creek drainage is, on the basis of the present study, believed to be the direct result of glacial modifications and not of stream capture through piracy. When maximum advance of the first ice sheet caused disruption of the newly formed drainageway that had supplanted the preglacial Teays-Mahomet River, a bypass channel was formed that skirted the ice margin. West of the ponded Licking River basin were the ponded Kentucky River and Eagle Creek basins. Presumably drainage from the east followed high-level channels into the Licking River basin and thence through upland channels not yet identified, into the ponded Eagle Creek basin. From the Eagle Creek basin to the ponded Kentucky River basin farther west, the torrents followed an integrated ice-margin channelway between small proglacial lakes fringing the ice margin. The southwest course of the present Eagle Creek appears to follow, roughly, this high-level bypass channel (pl. 1). The general character and extent of the proglacial lakes and high-level drainageways may eventually be more precisely defined through detailed mapping o the suricial deposits.

Drainage following the ice-margin channelway from the east reached the ponded preglacial Kentucky River basin in the vicinity of Worthville (Worthville quad., Kentucky). Because escape of the ponded waters to the west, across the Madison divide, was blocked by glacial ice, another escape route from the ponded Kentucky River basin had to be found. The writer suggests, as a working hypothesis, that the impounded waters rose to overtop briefly a low divide or divides between the Kentucky and Salt River basins. The points of overtopping are not known but may be the channels described by Leverett (1929) as being mostly below 800 feet in altitude and lying between valleys now tributary to the Kentucky River and those tributary to the Salt River. 
He $(1929$, p. 8$)$ noted that "these channels appear to be somewhat later than the Irvine formation, yet they date from a time prior to the main channeling of the Kentucky and Salt River." Inasmuch as the load carried across these divides from the ponded river basin was at a minimum, the divides may have been so little modified by erosion that today they are relatively inconspicuous terrain features.

West of the Madison divide, the channel now occupied by the Ohio River had likewise been overwhelmed and obliterated as a drainageway at maximum ice extent (pl. 1). Unlike the extensive drainage basin east of the Madison divide, drainage to the west consisted essentially of melt waters locally derived from the melting ice. Like the sector to the east, however, drainage appears to have been largely confined at first to small proglacial lakes that were later integrated into an ice-marginal stream flowing west along a channelway now represented by Harrods Creek (pl. 1; Ray, 1966). Because of the glacial outwash locally available to the ice-margin stream, the channelway was rapidly eroded and became a permanent terrain feature similar to the glacially formed lower course of Eagle Creek.

At the maximum advance of the ice sheet of Nebraskan age, melt water and local drainage from the entire area from northwest Pennsylvania to the vicinity of Louisville was funnelled to the Mississippi embayment and thence to the Gulf of Mexico through the preglacial Salt River gorge in the Knobstone-Muldraugh Hill escarpment. Volume of this drainage was, because of the melt water, much greater than the volume of flow of the present Ohio River.

\section{AFTONIAN INTERGLACIAL TIME}

There is little tangible evidence in the Ohio River valley region to enable a satisfactory reconstruction of the history of the first interglacial stage, the Aftonian. Evidence consists of the mature profile of weathering developed on Nebraskan drift and preserved beneath Kansan drift, and of stream valleys eroded into the drift-covered uplands after deposition of the Nebraskan drift and before deposition of the Kansan drift (Leighton and Ray, 1965; Ray, 1966).

Boundaries for Aftonian interglacial time are transgressive, indefinite, and, in the Ohio River valley region, indeterminate (Ray and Karlstrom, 1968). However, the advanced profiles of weathering and the amount of terrain dissection attributed to Aftonian time indicate that the Aftonian was much longer than was formerly believed. In northeast Iowa, for example, where, as in the Ohio River valley, both Nebraskan and Kansan drifts are present, Aftonian time was a period of weathering and stream dissection of the upland on which till of Nebraskan age is present. Trowbridge
(1966) was skeptical, because of the time requirements, that so much stream erosion could have been accomplished during Aftonian time. Willman and Frye (1969), however, supported Trowbridge's conclusion that the upland was dissected during Aftonian time and the corollary that the Nebraskan drift predated the valley cutting and the Kansan drift postdated it, a geologic history similar to that along the Ohio valley.

Theoretically, the ice sheet of Nebraskan age, after attaining its position of maximum expansion, began to wane, presumably as the result of a general climatic amelioration. The long-continued dissipation of the ice sheet was probably not uniform; rather, there were longand short-term regional reversals as well as local fluctuations along the melting ice margin. Whether the Nebraskan ice sheet completely disappeared during Aftonian time or lingered on in its nuclear region cannot be answered. Neither is it possible, on the basis of available evidence, to estimate the length of nonglacial time or to determine the time required for regeneration of the later Kansan ice sheet and for its movement to its position of maximum advancement. Stratigraphically, Aftonian time is observable only as an unconformity where weathered Nebraskan drift is overlain by Kansan drift, for no deposits referable to Aftonian time have been recognized in the Ohio River valley region.

On the undissected uplands where Nebraskan drift is overlain by Kansan drift, weathering started as soon as the Nebraskan drift was exposed by dissipation of the overriding ice and continued until the deposits were again covered by the advancing younger ice sheet of Kansan age. Because of poor drainage on the uplands, long-continued weathering resulted in a typical gumbotil profile characterized by a surficial horizon of heavy brownish-gray tenaceous clayey thoroughly decomposed till in which only the most resistant siliceous insoluble materials remain as randomly scattered pebbles. Such deeply weathered material is well represented in the Pleasant Valley section (Leighton and Ray, 1965), where truncation of the profile was at a minimum. Elsewhere, the overriding Kansan ice sheet has commonly truncated the profiles.

Gooding (1966) and Murray (1955) reported profiles of weathering that are here assigned to the Aftonian time. Gooding (1966) reported 4 feet of noncalcareous clayey mottled yellowish-brown and gray till at the Osgood section, and Murray (1955) reported about 7 feet of darkreddish- and greenish-brown compact clayey till containing abundant siliceous pebbles. Both tills are here interpreted to be of Nebraskan age, and the weathering profiles developed on them are, therefore, of Aftonian age, for the overlying younger tills are interpreted to be of Kansan age. In the Dabney section (p. 25) the profile has been so thoroughly truncated that almost none of 
the profile of weathering remains, yet the dark-brown compact crumbly calcareous till containing much chert and crystalline rock has the general appearance of a lower horizon of a weathering profile that had been produced in Aftonian time and later eroded and covered by Kansan drift. Where, as in the Lookout Heights and Airport sections, the compact clayey gumbolike profiles of weathering have been modified because of later improvements in drainage conditions, silttils have resulted. Silttil profiles are common in all but the undissected upland areas.

Dissection of the uplands by stream erosion in Aftonian time is best illustrated in northern Kentucky where both Nebraskan and Kansan tills are present (pl. 1). Along the outer margin of the Kansan ice sheet, outwash and till were deposited in valleys intermediate in altitude between the upland surface and the bottoms of the present stream valleys. The best example of a driftfilled valley is near an altitude of 500 feet along the north wall of Riddles Run (Rising Sun quad., KentuckyIndiana). There, a thick till section was revealed in a new roadcut in 1960 . About 20 feet of compact, oxidized, clayey, and highly calcareous till was exposed that contained fragments of local limestone and pebbles and cobbles of crystalline rock as much as 18 inches in maximum diameter. Fractures extending through this compact calcareous till were marked by limonite staining. Above the till, only 6 to 8 feet of leached till was preserved, indicating that erosion had almost kept pace with leaching along the steeply sloping valley wall. At the base of the leached till as well as in the lower unleached till, secondary calcareous concretions were abundant, and in places, larger cobbles were in part coated with secondary calcium carbonate. No "ghosts" or deeply rotted crystalline cobbles were noted. About a mile up the valley, an exposure of about 20 feet of leached silty fine sand was interpreted to be glacial outwash of Kansan age.

The presence of deep valleys filled with drift of Kansan age was confirmed during the winter of 1968-69, when a landslide revealed a bedrock channel along the south wall of Gunpowder Creek about 2 miles northeast of the Riddles Run outcrop of Kansan till. The silty sand filling of the channel was well exposed, and the lower part of the deposit contained large and abundant calcareous nodules that indicated a long period of weathering and a bountiful source of calcite. Because the ridge surface up to an approximate altitude of 750 feet is sandy, there is an estimated thickness of 200 feet, more or less, of Kansan outwash in the valley to provide the source for the secondary calcium carbonate nodules.

West of the Madison divide the newly organized Ohio River entrenched itself during Aftonian time far below the adjacent uplands, as indicated by an outcrop of Kan- san till (Ray, 1957) on a bedrock bench along the south wall of the Ohio River valley at the mouth of Phillips Branch (Bethlehem quad., Indiana-Kentucky). The bedrock bench is about 50 feet above the pool stage of the Ohio River and more than 300 feet below the adjacent upland that is mantled by deeply weathered Nebraskan drift. The bedrock bench is interpreted to be a remnant of a terrace formed by river erosion during Aftonian time, before the Kansan ice advance. Such deep trenching by the river was possibly the result of static rejuvenation because of the increased volume of flow produced by drainage-basin expansion during Nebraskan time. No other remnants of this terrace have been found along the Glaciated Ohio River valley.

No regional uplift is believed necessary to explain the amount of erosion accomplished during Aftonian time, for erosion was vastly aided along the major streams by melt-water torrents and debris transported during the waning of the Nebraskan ice sheet and by melt-water flow during the advance of the Kansan ice sheet. Doubtless, flow was also increased by the reversal of climatic conditions-from the warm dry interglacial time to the cool wet glacial climate. No evidence of crustal uplift or depression resulting from glaciation has been found in the Glaciated Ohio River valley region.

After the Nebraskan ice sheet had disappeared from the Glaciated Ohio River valley, the main stem of the river is believed to have followed once again the preglacial channel of the Manchester River from the Manchester divide to the vicinity of Hamilton, Ohio, where it turned southwest to follow the south-flowing course of the Cincinnati (Hamilton) and Kentucky Rivers to the Madison divide, and thence west along the course of the preglacial northern branch of the Salt River (fig. 9)-a course in general similar to that of today except in the Cincinnati region. The new bypass channels formed during the maximum advance of the Nebraskan ice sheet were presumably of too short a duration to have become permanently established.

\section{KANSAN GLACIATION}

The second ice sheet to invade the Glaciated Ohio River valley region from the northeast was of Kansan age. In many respects it appears to have been similar to, though somewhat less extensive than, the ice sheet of Nebraskan age. Deposits of both glaciations lack surficial topographic expression, and postdepositional weathering has been so great that the drifts are indistinguishable in sections in which only a single till is exposed. The lack of topographic expression may be the result of original drift deposition, the result of longcontinued postdepositional weathering and erosion, or, most likely, a combination of both. Because no precise means has been devised for field differentiation between the Nebraskan and Kansan drifts in shallow expsosures 
of a single drift, the mapped boundaries (pl. 1) are of necessity generalized and may require revision as more detailed information is gathered.

Flint (1957) stated that the Kansan drift, like the Nebraskan, was wholly overlapped by the next younger drift, the Illinoian. In the region of the Glaciated Ohio River valley, however, this relationship is not valid, for, according to the interpretations presented here, the Kansan ice sheet was much more widespread than the Illinoian ice sheet (pl. 1).

At its position of maximum advancement, the Kansan ice sheet was slightly less extensive than the earlier, Nebraskan ice sheet except in the south part of the Scottsburg lowland, along the base of the KnobstoneMuldraugh Hill escarpment. There, the marginal part of the Kansan ice sheet was not sufficiently vigorous to override the escarpment, as did the Nebraskan ice sheet, and was deflected to the south, overriding the Nebraskan drift, possibly as far as the Ohio River. Meltwater torrents coursing through the Ohio River valley may have halted, in this area, the final advance of the deflected ice sheet to the south.

On the uplands of northern Kentucky, south and southwest of Cincinnati, the forward movement of the Kansan ice sheet was uninhibited, for at that time the deep gorgelike valley now occupied by the Ohio River between the mouths of the Great and Little Miami Rivers did not exist. Furthermore, the valley walls along the ancient channel looping to the north around Cincinnati to the vicinity of Hamilton, Ohio, were not high enough to halt the vigorous forward movement of the advancing ice sheet.

To the southwest, no evidence has been found that the Kansan ice sheet reached the present Ohio River valley between Rising Sun and the Madison area (pl. 1). It is suggested here that a broad strip of upland adjacent to and back from the Ohio River valley in southeast Indiana was not glaciated in Kansan time. On this strip of upland, glaciated only in Nebraskan time and partly dissected in pre-Kansan (Aftonian) time, no exposures have been observed in which there is more than a single deeply weathered glacial till, believed to be of Nebraskan age. So highly modified is this till through weathering that commonly surficial deposits on the upland remnants are not recognized as deeply weathered glacial till (Bushnell, 1958?). The coarse till and surficial boulders associated with the Kansan till in northern Kentucky, south and southwest of Cincinnati, are not present in this area. The shallow exposures are largely of silt containing scattered siliceous insoluble materials. Where postdepositional erosion has left larger remnants of the original flat upland surface and the weathered till is poorly drained, the till tends to be heavy, clayey, and tenacious a few inches below the surface.
Northwest of the upland strip of exposed Nebraskan drift, in the area of surficial Kansan drift (pl. 1), a few sections indicate two distinct glacial tills, and scattered boulders are locally present. Sections of thick, surficial till are in places calcareous at depths generally greater than 10 feet.

In those sections described by Murray (1955) at the Muscatatuck State School (Spillway section) and at the Scott County Stone Co. quarry, two glacial drifts are exposed that he interpreted to be of Illinoian and Kansan age. This interpretation is herein challenged, and the older drift at the Spillway section is assigned a Nebraskan age (p. 24). The younger surficial drift, first referred to as Illinoian by Leverett, is here referred to a Kansan age on the basis of its deep profile of weathering, for it is leached to a depth of 12 feet below a surficial 5 feet of clayey gumbolike weathered till. At the Scott County Stone Co. quarry, the upper till is likewise reported in part clayey and is leached to a depth of 14 feet. This leaching is greater than that on Illinoian till elsewhere and is characteristic of the deposits that have been referred to a Kansan age in southwest Ohio by Durrell (1961).

A truncated and surficially modified exposure in a pit on the uplands at Madison, Ind. (south of State Route 107, NE1/4 SE1/4 sec. 21, T. 4 N., R. 10 E., Clifty Falls quad., Indiana), is leached to a depth of approximately 10 feet. Many erratics, 2 to 3 feet or more in diameter, are scattered across the pit floor. These erratics are seemingly characteristic of the Kansan drift.

Abundant wood fragments were reported to have been recovered many years ago from deep sewer excavations in the poorly drained till on the flat uplands in the newer residential area of Madison, Ind., not far from the pit containing the scattered glacial boulders (G. T. Wickwire, oral commun., 1964). No attempt was made to determine the type of wood or its age by carbon-14 methods, for presumably the wood was too old. One is reminded, however, of the wood in the lower part of the upper till in the Scott Stone Co. quarry (p. 25). In both places the wood-bearing till, formerly assigned an Illinoian age, is here referred to a Kansan age.

Immediately west of Scottsburg, Ind., the best till section of southeast Indiana was studied in the field at the time it was fresh (1966). A succession of two deeply weathered deposits was exposed in an artificial cut in a lowland area. Weathering of the younger surficial till is so advanced that the till is assigned a Kansan age, and the underlying till is therefore assigned a Nebraskan age.

West and south of the Madison area, on the Muscatatuck regional slope, the Kansan ice sheet is believed to have reached the present Ohio River valley and to have crossed it locally (Ray, 1957, 1965b, 1966). 


\section{Scottsburg section}

[West side of artificially straightened and deepened section of Honey Creek in NW1/4 sec. 19, T. 3 N., R. 7 E., $250 \mathrm{ft}$ north of Indiana State Highway 56 and $400 \mathrm{ft}$ west of cloverleaf intersection with Interstate 65, Scottsburg quad., Indiana]

Wisconsin (Peorian) loess:

Thichues

8-10 in. light-gray noncalcareous silt, underlain by buffyellow somewhat clayey silt mottled with gray; crumbles to small flaky peds; iron oxide pellets

Kansan drift:

Heavy compact yellow noncalcareous silty clay with pronounced surficial drying cracks; some gray mottling and veining; small pebbles of siliceous insoluble materials scattered at random throughuut. Pronounced break in slope at top of zone on eroded surface ............. 3-4

Compact buff-yellow noncalcareous clayey silt; surficial drying cracks not as prominent as in overlying zone; gray veining and many iron oxide pellets ................. 4-5

Similar to overlying zone but containing many secondary calcite pellets, irregular sheets, and masses; pellets of iron oxides increase with depth; a few small siliceous insoluble pebbles scattered at random but no crystalline-rock com-

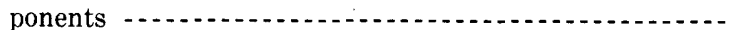

Nebraskan drift:

Red-brown to gray noncalcareous clayey surficial layer containing a few secondary calcareous nodule contaminants from overlying layer; prominent drying cracks; black staining along fractures. The few crystalline rocks in this layer crumble readily on exposure .................. 2t

Pebbly calcareous till, buff at surface; grades downward to hard compact blue-gray till at depth. Limonite staining along fractures; a few lenses of brown sand. Crystalline components to $2 \mathrm{ft}$ in diameter; rotten in upper part but fresh at depth. Limestone cobbles and pebbles are striated, Covered. soled, and faceted

The frontal margin of the enfeebled and extended ice sheet may have been halted, except locally and for brief periods, by the melt-water torrents carried by the river, and the Ohio River valley may essentially mark the maximum position of advancement attained by the ice sheet of Kansan age between the Madison and Louisville areas. Where the ice sheet briefly crossed the valley, it deposited drift in subsummit positions within the mouths of small tributary valleys cut below the upland surface during Aftonian time. At and downstream from the mouth of Phillips Branch (Bethlehem quad. Indiana-Kentucky), Kansan drift is present on a bedrock bench on the south side of the Ohio River valley (Ray, 1957). This elongate morainelike mass of deeply weathered till was described but not explained by Fowke (1933), who inferred that it was possibly a river terrace. When first examined in 1956, the exposure along a roadcut adjacent to Phillips Branch was fresh, and an ideal profile of weathering was exposed that extended from calcareous till resting on bedrock to a surficial silt containing scattered siliceous insoluble pebbles mantled by a thin layer of Peorian loess. The bedrock terrace on which the till rests is now interpreted to be of Aftonian age.
No evidence has been found to suggest that this part of the river valley was ice dammed for any extended period of time above the Phillips Branch, yet the river may have been temporarily ponded so that melt waters were forced to escape once again through the Harrods Creek valley, as postulated for Nebraskan time. Comparison of the weathered Kansan till at Phillips Branch with the more deeply weathered silttil of Nebraskan age on the adjacent uplands, especially on nearby Covington Ridge, indicates the long time interval and amount of weathering possible during the Aftonian interglacial time.

Evidence for Kansan drift on the uplands of northern Kentucky south and southwest of Cincinnati, Ohio, has been discussed with the evidence for Nebraskan drift on the uplands (Leighton and Ray, 1965; Ray, 1965b, c). There, the younger, surficial, moderately to welldrained Kansan drift is commonly a silttil in which siliceous insoluble materials, largely chert pebbles, are scattered at random. Only in the flat poorly drained areas is the weathered Kansan drift clayey and gumbolike. Near the present Ohio River valley, shallow exposures of silttil of Kansan age may be confused with a thin overlying blanket of weathered noncalcareous loess of Peorian (Wisconsin) age. The two can be readily separated, however, on the basis of the lack of scattered insoluble materials in the loess. Farther from the river valley today, where loess is thin or absent, cobbles of crystalline rock and quartzite of Kansan age are thinly scattered across broad areas of uplands, but, as in southeast Indiana, they have been avidly collected and largely removed as exotics for ornamental purposes. These cobbles, present only on the surface of the Kansan drift, may be genetically related to that drift.

Along the south and southwest terminus of the Kansan drift on the uplands of northern Kentucky, drift is present in small valleys cut below the upland surface in Aftonian time by headward-eroding tributaries of the newly established Ohio River. Both glacial till and outwash from the Kansan ice sheet were deposited in these valleys, as observed along Riddles Run and Gunpowder Creek (p. 34). The best known valley fill, here assigned a Kansan age, is the so-called "Middle Creek conglomerate" composed of cemented sand, gravel, and cobbles of limestone and a few crystalline rocks and quartzite. This conglomerate occupies a broad channelway cut below the general upland surface between Gunpowder and Woolper Creeks (Rising Sun quad., Kentucky-Indiana, and Lawrenceburg quad., Kentucky-Indiana-Ohio) and is widespread in the vicinity of Commissary Corner and the valley of Middle Creek. The area that includes the conglomerate is now deeply eroded, especially by Middle Creek, to narrow valleys with rugged, precipitous walls 60 feet or more 
high. The "Middle Creek conglomerate" has been compared and correlated with the nearby "Split Rock conglomerate" that crops out along and back from the present Ohio River adjacent to the mouth of Woolper Creek, about 4 miles west and north of Commissary Corner. These conglomerates have been an unsolved geologic problem since they were first described by Dr. John Locke in the Cincinnati Gazette for September 23, 1845.

Sutton $(1877,1879)$, after describing the two conglomerates, reached the conclusion that, despite their similarities, they were not of the same age. The "Split Rock conglomerate," about 300 feet lower than the "Middle Creek conglomerate," he interpreted to be the younger: "The one [Middle Creek conglomerate] dating back to a period prior to the formation of our valleys, the other after the river [Ohio] had cut down its channel 450 feet***" (Sutton, 1879, p. 111).

In 1902 and again in 1929, Leverett (1929, p. 55) refuted this interpretation and stated,

From the wide difference of level at which these conglomerates occur, Sutton drew the inference that they are widely different in age, it being assumed that they are remnants of river terraces. They appear, however, to be better classed as exceptionally stony till, rather than an assorted stream deposit. The wide difference in altitude may thus signify nothing as to time relation.

Leverett's conclusion (1929, p. 56) was evasive-“These conglomerates*** are probably a result of the bridging of the Ohio Valley by the ice sheet, but just how they were produced is a matter of speculation and variety of opinion." Durrell (1956), essentially following Sutton, reached the conclusion that the "Split Rock conglomerate" was of Illinoian age and that the "morainelike deposits on the upland near Commissary Corners, Kentucky, and the 'Middle Creek conglomerate' just to the south are pre-Illinoian terminal deposits."

One can reasonably infer that conditions similar to those in northern Kentucky were present in southeast Indiana along the margin of the Kansan ice sheet between Rising Sun and Madison and that deposits of Kansan age might be found in valleys cut below the Nebraskan drift-mantled upland surface in Aftonian time. No such deposits, however, have been located (Rich, 1956). Erratics found on valley walls and in creek beds are like those of northern Kentucky and are believed to have been derived secondarily by erosion of the Nebraskan drift on the uplands.

The west boundary of the surficial Kansan drift in southeast Indiana is poorly defined and in part masked by the overlapping deposits of younger glaciations (pl. 1). From the Ohio River north to the valley of the Muscatatuck, the outer terminus of the ice sheet and deposits of Kansan age appear to follow roughly the base of the Knobstone-Muldraugh Hill escarpment. In places, proglacial lakes appear to have been impounded between the irregular ice margin and the irregular base of the escarpment. Remnants of deeply weathered lacustrine deposits indicate the presence of such lakes.

Where the Muscatatuck River and the East Fork of White River combine to cut through the escarpment on their course to the west, evidence of Kansan drift has been removed by post-Kansan stream erosion and alluviation. However, a boundary separating the Kansan till on the east from the overlapping till of Illinoian age on the west has been drawn along the base of the massive Chestnut Ridge terminal moraine (Cox, 1879; Leverett, 1902, 1929) of Illinoian age and along its continuation to the southwest, the Tampico Ridge moraine (pl. 1). This boundary has been arbitrarily continued north from the Chestnut Ridge moraine, across the broad outwash deposits of the East Fork of White River, to the point in northwest Jennings County where drift of the youngest glaciation, the Wisconsin, overlaps all older deposits. The extent of the pre-Illinoian glacial drifts west of this boundary is not known, but a small area of surficial till has been mapped as Kansan by Wayne (1958).

Age determinations of pre-Wisconsin glacial drift from northwest Jennings County to the valley of the Great Miami River have proved difficult for many reasons, one of the most important being the paucity of deep outcrops on the upland flats. Where outcrops are present on slopes immediately below the summit levels, they are generally incomplete and truncated by erosion. The problem posed was whether a strip of glacial drift of Illinoian age intervenes between the outer margin of the drift of Wisconsin age and the widespread drift of Kansan age in southeast Indiana (pl. 1). At first, on the basis of field study, the writer believed that the drift of Illinoian age appeared from beneath the Wisconsin drift border midway across Decatur County and that, from that point to the valley of the Great Miami River, Illinoian drift was present as a surficial deposit. Attempts, however, to locate the southern boundary of this postulated strip of Illinoian drift have proved unsuccessful in the field, and the belief in an intervening strip of Illinoian drift has been abandoned, despite the fact that there are marked differences in the terrain and seemingly in the deposits of pre-Wisconsin drift in Franklin and in adjacent Ripley and Dearborn Counties to the south.

It first appeared to the writer that the marked change in the landscape north and south of the drainage divide between the basin of the Whitewater River and that of the tributaries to the more distant Ohio River (fig. 3) indicated a possible difference in the age of the drifts and the geologic history on either side of the divide. North of the broad flat-topped drainage divide, the streams are more steeply graded, and the terrain has greater relief 
as the result of headward erosion by tributaries of the nearby Whitewater River. Steep-walled valleys, in places cut into bedrock, deeply dissect the drift-mantled upland surface. South of the divide, the relief is less, the valleys are generally less steep walled, and the driftmantled upland is less dissected. The different types of terrain are well shown on the Metamora, Batesville, and Pierceville quadranges, Indiana.

Gooding $(1957,1963)$, following the earlier studies of Leverett and others, recognized only tills of Illinoian and Wisconsin age in the drainage basin of the Whitewater River. Thus, he was led to the conclusion that only drift of Illinoian age is present on the dissected uplands south of the boundary of the Wisconsin drift in southeast Indiana. If this is true, then, as he suggested (1957, p. 28), the valley of the West Fork of the Whitewater River was probably cut during Sangamon interglacial time, that is, in post-Illinoian-pre-Wisconsin time. This conclusion is not in harmony with the generally held belief that major streams were cut to their greatest depth during the "Deep Stage" before the invasion of the Illinoian ice sheet. A pre-Illinoian (Yarmouth) age for "Deep Stage" erosion is supported by the presence of drift of undoubted Illinoian age within the bedrock valleys of the major streams, such as the Ohio and Great Miami Rivers.

Examination of the relationship of the bedrock terrain and the glacial deposits indicates that south of the border of the Wisconsin drift and east of Decatur County in southeast Indiana, the pre-Wisconsin drift in the drainage basins of the Whitewater River and of the tributaries to the Ohio River is confined to the upland flats, remnants of the preglacial Dearborn upland, and to the relatively shallow valleys cut into the upland in post-Nebraskan, Aftonian time. If the present major valleys, deeply cut into bedrock and later alluviated, are the result of "Deep Stage" erosion, commonly believed to be of pre-Illinoian (Yarmouth) age, one would expect that drift of Illinoian age would be present in the deep bedrock valleys. No drift is present; therefore, if one accepts a Yarmouth age for "Deep Stage" erosion, one is led to the conclusion that the oldest drift in this area was deposited in pre-Yarmouth time, before formation of the deep valleys, and is thus of pre-Illinoian, presumably Kansan, age, as shown on plate 1, and that in this part of southeast Indiana, no drift of Illinoian age is present between the southern limit of the drift of Wisconsin age and the Ohio River valley. This conclusion is supported by the mature profiles of weathering developed on the drift; for example, in the till section on Delaware Road south of Batesville (sec. 32, T. 10 N., R. 12 E., south of Bobs Creek, Batesville quad., Indiana) there is exposed about 8 to 10 feet of silttil that contains many scattered pebbles of siliceous insoluble materials. Such deep weathering is not expected in till of Illinoian age.
Gooding $(1957,1963)$ described in this region a single terrace remnant to which he assigned an Illinoian age on the basis of its height (unspecified) above the level of the terraces related to the drift of Wisconsin age and its great depth of leaching-about 18 feet through loessmantled terrace alluvium into the underlying till. Such a mature profile of weathering is here interpreted to be preIllinoian. Because Gooding interpreted this terrace to be of Illinoian age but reported no till that could be interpreted to be of Illinoian age within the bedrock valley of the West Fork of the Whitewater River, he (1957, p. 28) reached the conclusion that the valley was probably "established" in post-Illinoian (Sangamon) time, thus rejecting the "Deep Stage" erosion of Yarmouth time as the time of deepest stream cutting. This interpretation is open to question when examined and compared with events in the nearby Great Miami River valley, to which the Whitewater River is tributary, and in the Ohio River valley, to which the Great Miami River is in turn tributary. In both the Great Miami and the Ohio River valleys, tills of undoubted Illinoian age are present within the deep bedrock valleys cut in pre-Illinoian (Yarmouth) time.

No remnants of valley trains assignable to a Kansan age have been observed along the Glaciated Ohio River valley, and, as in the case of the valley trains of Nebraskan age, the writer believes that no remnants have survived. That there were valley trains is undoubted, but because the valleys of Nebraskan and Kansan time have subsequently been highly modified, it would appear that weathering and erosion have removed all evidence of the presence of valley trains. Similarly, whatever loess may have accumulated along the glacially alluviated drainageways in Nebraskan and Kansan time also appears to have been completely removed by later weathering and erosion in the Glaciated Ohio River valley region.

Recognition of a Kansan age for the widespread surficial glacial till formerly thought to be of Illinoian age in southeast Indiana, southwest Ohio, and northern Kentucky changes many concepts previously held. It indicates that in this region the Kansan drift was far more extensive than Illinoian or Wisconsin drifts. Deposits of Kansan age overlap earlier deposits of Nebraskan age, which normally extend beyond the Kansan deposits as the surficial till. Thus, the earliest (Nebraskan) glaciation was the most widespread, and each succeeding glaciation in this area was less extensive. Furthermore, the topographic position of the tills of Nebraskan and Kansan age indicates that they were much more closely associated in time than were the last two glaciations, the Illinoian and Wisconsin. This suggests that the longest and therefore the most important interglacial time was the Yarmouth, between the glaciations of Kansan and Illinoian age. 
Elsewhere, as in southwestern Indiana and southern Illinois, the Illinoian drift appears to have been the most widespread and to mask the underlying Kansan drift and possibly a Nebraskan drift not yet recognized. This widespread expansion of the Illinoian ice sheet may have been in part due to the character of the terrain formed by erosion during Yarmouth time, the time of greatest Quaternary stream erosion. Perhaps the terrain, especially in the Great Lakes region, allowed each successive advance of the ice sheets from the northeast to be diverted more and more to the west rather than to the southwest.

\section{DRAINAGE MODIFICATIONS RESULTING FROM THE KANSAN GLACIATION}

Advance of the Kansan glacier and subsequent modification of the Ohio River's flow in the glaciated part of the river valley are believed to have followed a pattern similar to that of Nebraskan age. Inasmuch as the general regional configuration and the time of maximum expansion of the Kansan ice lobe, or lobes, are not known, it is difficult to reconstruct the exact sequence of events effecting the regional drainage pattern and its modifications. Drainage modifications in Kansan time appear to have been minimal, however, when compared with the drastic changes of the earlier Nebraskan or later Illinoian times.

When the ice sheet of Kansan age advanced into the basin of the Ohio River, the river was a southwestward through-flowing stream from above the ancient Manchester divide to the mouth of the gorge through the Knobstone-Muldraugh Hill escarpment-a course inherited and stabilized after the modifications caused by the glaciation of Nebraskan age. Except for the channel loop to the north around the Cincinnati area, the river followed a course essentially the same as that of today, although its valley was shallower and its many small tributary streams, largely formed during Aftonian time, were much shorter and had not yet deeply dissected the upland flats to produce the mature topography of today adjacent to the main valley.

Drainage modifications of Kansan age along the Glaciated Ohio River valley are, like those of Nebraskan age, highly speculative for want of precise data because of subsequent weathering and erosion. Above the Cincinnati area, the Ohio River appears to have been unobstructed by the Kansan ice sheet, which apparently did not reach as far as the river valley. The valley served, however, as an important sluiceway for glacial melt waters and glaciofluvial outwash from a broad sector of the ice front in Ohio, northwest Pennsylvania, and perhaps even western New York State.

In the basin of the Glaciated Ohio River valley, the first blockage of the river by the advance of the Kansan ice sheet appears to have been along the great loop of the river around the present site of Cincinnati. As soon as this sector of the river was overwhelmed, the river upstream, already swollen by glacial melt waters, was ponded and rose rapidly within the main and tributary valleys. Presumably, the waters of the Ohio-Licking River basin overflowed into the still ice free Kentucky River basin to resume their westward course, but the point at which the impounded waters overflowed has not been determined. When the main valley above Rising Sun (pl. 1) became ice covered and inoperative as a drainageway, part of the melt waters may have been diverted into the lower Ohio through the Eagle CreekKentucky River drainageway.

Possibly, when the ice sheet first blocked the drainage above Cincinnati, melt-water torrents in the ponded Licking River valley rose to overtop a divide about a mile east of the Anderson Ferry (Covington quad., Kentucky-Ohio). There, two streams, one draining to the east and the other to the west from a col in the divide, may have formed a channel to the west for the release of the ponded waters. If so, this spillway was used only briefly before it was overwhelmed by the ice sheet and rendered inoperable, as suggested by Ray (1966). As the ice sheet waned and the col was uncovered, this. drainageway may have been used briefly once again and may have been further enlarged by torrential stream overflow before the divide again became effective in post-Kansan-pre-Illinoian time.

Assuming that the advancing Kansan ice sheet, like the Nebraskan ice sheet, covered the Madison divide area, an assumption not yet proved, then waters along the ice-free Ohio from Rising Sun to Madison were again ponded, and the flow was again reversed up the Kentucky River, rising rapidly to overtop a low divide separating the Kentucky River from the Salt River drainage. This divide, as yet undetermined, may have been the same as that postulated for Nebraskan time.

Although glacial till of Kansan age has been recognized at places on the south side of the Ohio River valley between Madison and Louisville (Ray, 1957), none has been observed on the uplands south of the valley. Apparently, the Kansan ice sheet was unable to climb from the valley onto the highlands of northern Kentucky. In crossing the valley, it must have, at least for brief periods, blocked the river, yet no evidence for such periods of ponding has been observed. Presumably the evidence has been obliterated by later weathering and erosion. Some drainage at this time might have escaped through the Harrods Creek channelway from ponded north-flowing tributaries to the Ohio, but no lacustrine deposits of Kansan age have been found in the presumably ponded valleys. Such lacustrine deposits may have been flushed from the valleys by deep erosion during Yarmouth time.

At the maximum extension of the Kansan ice sheet, all melt-water drainage in southeast Indiana, Ohio, and 
farther east was channelled through the two passageways in the Knobstone-Muldraugh Hill escarpment in southern Indiana: the channel of the preglacial Salt River now occupied by the Ohio River, and the channel of the combined Muscatatuck River and East Fork of White River to the north.

At the close of Kansan time, the Ohio River in the glaciated part of its valley seemingly occupied essentially the same channel as it did after Nebraskan time. The meandering channel of the preglacial Kentucky River between the Madison area and the Great Miami River valley had been somewhat straightened to conform to its present-day route, but upstream, the main stem of the Ohio River continued to follow the great loop to the north around the Cincinnati area. All connections with the obliterated Teays-Mahomet drainage system had been erased during Nebraskan time, and the Ohio was now the dominant through-flowing river east of the Mississippi.

\section{YARMMOUTH INTERGLACIAL TIME}

When the Kansan ice sheet had waned and finally disappeared from the basin of the Ohio River, Yarmouth interglacial time was initiated there. This, the longest of the three Quaternary interglacial times, lasted until the advance of the third great ice sheet, the Illinoian, into the basin of the Ohio River. During Yarmouth time, the Glaciated Ohio River valley and its drainage basin were profoundly affected by long-continued weathering and erosion.

Yarmouth interglacial time marks the most important break in the succession of Quaternary glaciations, because the deeply weathered, eroded, and highly modified pre-Yarmouth glacial deposits sharply contrast with the less weathered and eroded post-Yarmouth deposits. In general, pre-Yarmouth glacial deposits do not present a readily distinguishable glaciated terrain, whereas there is little doubt of the glaciated nature of the terrain underlain by post-Yarmouth deposits of Illinoian and Wisconsin age. Furthermore, Yarmouth time was a time of deep stream entrenchment into bedrock, providing the "Deep Stage" drainage described by Stout, Ver Steeg, and Lamb (1943) along the Glaciated Ohio River valley and its tributaries. Since Yarmouth time, the major streams have probably flowed only on thick post-Yarmouth alluvium within their bedrock valleys and presumably are not downcutting into bedrock, as in Yarmouth time. If this is true, then by the close of Yarmouth time, relief along the Glaciated Ohio River valley was greater than at any other time during the Quaternary Period.

Like the earlier Aftonian interglacial time, Yarmouth time has transgressive upper and lower boundaries. As soon as the glacial deposits of Kansan age were exposed by the waning ice sheet, their modification through weathering and erosion began. Where Kansan drift is still an unconsolidated surficial deposit, weathering and erosion have continued to the present time. Where Kansan deposits have been covered by Illinoian or Illinoian and Wisconsin drifts, or by loess, they are less deeply weathered, for weathering has been inhibited or appreciably slowed by the mantling deposits. On poorly drained upland flats, deep weathering of the surficial Kansan drift, like that of the Nebraskan drift, has left a silty clay, gumbolike residuum largely resulting from leaching of the limestone and silty calcareous shales incorporated in the glacial drift. The included crystalline rocks, a small percentage of the till, have been almost completely decomposed and destroyed in the upper part of the profile of weathering, where their absence is conspicuous. Only small insoluble siliceous pebbles, commonly so weathered as to be punky, remain. These are scattered at random throughout the surficial silty clays or clayey silts.

On the poorly drained upland flats, in areas of ground moraine of Nebraskan and Kansan age, the original clays and the finer weathering products have tended to wash from the slight elevations into the adjacent shallow depressions on the original surface. This levelling process has resulted in a relatively smooth surface underlain by silty, gumbolike clays of variable thickness that in part have formed by weathering in situ and in part have been transported by colluviation from the adjacent higher elevations. Where upland areas have remained relatively undissected and therefore poorly drained, the clayey, gumbolike layers of the profile of weathering have inhibited downward percolation of surficial water; thus, subsurface weathering has been slowed, and highly calcareous glacial drift occurs in places at shallow depths below the clayey surface horizon. Where the uplands have been well dissected through the headward erosion of small streams, especially in areas near the Ohio River, the clayey components of the surficial layers have apparently been flushed from the deposits by ground-water movement, so the remaining product is largely the ubiquitous silt containing the insoluble siliceous pebbles scattered at random throughout.

When the Kansan ice sheet melted and probably disappeared during the long Yarmouth time, water that had been stored in the ice sheet on the land surface returned to the sea to produce a rise in sea level of indeterminate but appreciable magnitude. At the same time, melt-water torrents and glacial debris that had poured into proglacial drainageways from the waning ice sheet were gradually reduced and eventually halted. Thus, when the ice sheet had completely disappeared from the drainage basin of the Ohio River, flow of the 
river was drastically reduced, and glaciofluvial debris ceased to pour into the main river channel. No longer was a valley train of fluvioglacial outwash being built in the Ohio valley. A rising base level for the river, a reduction in flow, and a reduction in introduced load suggested to Russell $(1940,1944)$ and Fisk $(1944)$ that interglacial time was a time of stream aggradation rather than degradation. Field observations, however, do not support such a belief along the Glaciated Ohio River valley, where degradation was predominant during interglacial time.

The problem of degradation versus aggradation during interglacial time has been discussed elsewhere by Ray (1965a), who was led to the conclusion (p. 28) that:

Between the times of glaciation when the [Ohio River] drainage basin was ice free, river volume and velocity decreased sharply. The river, however, flowing on alluvial fill, had available a ready supply of transportable material. Because of the increased channel slope, inherited from the valley train, the river was competent to erode, thereby increasing its velocity in an attempt to adjust to the new condition.

During the long Yarmouth interglacial time, the degrading Ohio River and its tributaries removed most of the glaciofluvial alluvium within their valleys and cut deeply into bedrock along the river valley. Whatever inequalities may have remained as the result of previous integration of the drainage basins and removal of the Madison divide appear to have been smoothed at this time.

The scenic features along the Glaciated Ohio River valley are largely the result of deep stream erosion and entrenchment during Yarmouth time. The deep, steepwalled bedrock gorge through which the river now flows was largely the product of erosion in "Deep Stage" time, when relief along the valley was greater than today. Perhaps the most spectacular section along the gorgelike valley is near Madison, Ind., where for a few miles both upstream and downstream the valley is narrow and its precipitous walls rise almost 400 feet from the level of the river to the adjacent flats of the Dearborn upland or the Muscatatuck regional slope. Short, steeply graded tributaries along this section are characteristic, especially those from the north, whose valleys were largely cut in post-Kansan time.

For a few miles downstream from Madison, Ind. (pl $2 A$ ), creeks draining to the Ohio River from the Indiana bank are short, steeply graded, and sharply V shaped. Small waterfalls are common in these valleys but are unique to these few miles of the Ohio River valley between Cincinnati and its mouth. They are the result of interruptions in the steep stream gradients caused by thick erosion-resistant bedrock layers interbedded in sections of thin shales and shaly or silty limestones. Where the erosion-resistant layers are absent and the valleys are entrenched only in the thin shales and limestones, especially those of the Eden Stage, small riffles and cascades result from the irregular erosion of the bedrock, as pointed out by Fowke (1933) in his description of this part of the river gorge.

The largest and most spectacular waterfall is Clifty Falls on Big Clifty Creek, immediately west of Madison, Ind. (pl. $2 A$ ). This waterfall, about 90 feet high, is the center of attraction in Clifty Falls State Park. Four smaller waterfalls are present in tributaries entering Big Clifty Creek below Clifty Falls. Prior to the deep entrenchment of Big Clifty Creek in Yarmouth time, probably in preglacial time, Big Clifty Creek may have been the largest creek in the headwaters of the Salt River tributary that followed the present Ohio River valley west from the preglacial Madison divide. Heading on the back slope of Laughery escarpment almost at the east edge of the Muscatatuck regional slope, Big Clifty Creek is generally believed to have followed in its lower course the valley now occupied by Hog Trough Creek, which is separated from the present Ohio River valley by the Devils Backbone (pl. 2A). In Yarmouth time, during formation of the present Ohio River channel across the col in the Madison divide, the valley wall between Big Clifty Creek and the present Ohio River was removed by erosion, and Big Clifty Creek was captured by the Ohio, leaving the Devils Backbone as an isolated hill or "island."

A feature somewhat analogous to the Devils Backbone near Madison is present immediately upstream from Carrollton, $\mathrm{Ky}$. (pl. $2 B$ ). There, a narrow bedrock ridge separating the valley of the meandering lower Kentucky River from the main Ohio River valley was breached, leaving a bedrock "island" that today rises 380 feet above the normal pool stage of the Ohio River. This bedrock mass, now the site of General Butler State Park, is roughly triangular in outline, and has precipitous walls rising above the surrounding alluvial valley fill and an isolated mass of glacial till. The east and west sides of the bedrock "island" are wide-radius curving slopes marking ancient meander scars of the Kentucky River. The north-facing escarpment marks the relatively straight continuation of the now-breached south wall of the Ohio River valley.

Inasmuch as the preglacial Kentucky River followed a now-abandoned high-level channel from a point several miles up the Kentucky River from its mouth to join the Ohio River about 5.5 miles above its present confluence (fig. 10), the great meander scar east of General Butler State Park along the lower Kentucky River is Quaternary in age. Glacial till in the abandoned high-level channel is interpreted to be of Nebraskan age, so the meandering channel in the lower course of the Kentucky River is believed to be post-Nebraskan in age, probably 
initiated by erosion in Aftonian time. Near the close of "Deep Stage" erosion in Yarmouth time, the narrow bedrock ridge between the Ohio and lower Kentucky River valleys was breached by the widening of the Ohio River valley, and a broad col was formed. There is no evidence, however, that the col was ever crossed by either the Ohio or Kentucky river. Its existence before Illinoian time is, however, undoubted, because a large mass of Illinoian till is present in and south of the col. Lack of information on the configuration of the buried bedrock surface in the area of the col hinders definite and precise interpretations.

Thus, the long Yarmouth time throughout the Glaciated Ohio River valley region can be summarized as a time of stream degradation and of cutting of the deep bedrock channels associated with the "Deep Stage" erosion of Stout, Ver Steeg, and Lamb (1943). It was a time of deep and rapid erosion by tributary streams in their attempt to remain graded to the master stream. Headward erosion of tributary streams into the upland flats, glaciated in Nebraskan or in Nebraskan and Kansan time, markedly reduced the areal extent of the uplands and improved drainage conditions. A rugged mature topography formed in places along the Ohio valley, especially in the region of the Dearborn upland. Yarmouth time was a time of deep weathering of residual glacial deposits on the uplands and a time of rapid downcutting and grading of the Ohio River valley, especially in the vicinity of the preglacial Madison divide.

\section{ILLINOIAN GLACIATION}

The third great Quaternary glaciation, the Illinoian, is commonly believed to have been the most extensive of the classic glaciations in the midwestern United States. That the ice sheet was wider and spread farther south than any other ice sheet is well known (see Flint and others, 1959). Studies on which this report is based indicate, however, that the Illinoian ice sheet in the region of the Glaciated Ohio River valley was not as widespread as formerly believed. Till of Illinoian age in northern Kentucky is now believed to be restricted to isolated patches within the bedrock Ohio River valley and to a narrow belt along the Ohio River for a few miles above Cincinnati (pl. 1; Durrell, 1961; Ray, 1965a, b, 1966). Furthermore, the widespread till in southeast Indiana, formerly believed to be of Illinoian age, is here reinterpreted to be of Kansan age or older.

Because of the exaggerated local relief produced by "Deep Stage" erosion during Yarmouth time, the configuration of the ice sheet of Illinoian age did not follow that of the earlier ice sheets. As the Illinoian ice sheet advanced, it appears to have been so influenced by the topography that in its movement to the southwest it split into two lobes-the Clermont of southwest Ohio and the
Jackson of east-central Indiana (named for Jackson County, Ind.) - and a narrow sinuous ice tongue that extended down the Ohio River valley (pl. 1). The highland area centering in Randolph County of east-central Indiana may have been the feature that split the ice sheet, advancing from the northeast, into these two lobes.

The position of the ice margin between the two lobes is not known, for the glacial deposits of Illinoian age have been covered by deposits of Wisconsin age, and these later deposits rest directly on Kansan till in east-central Indiana (pl. 1). A long narrow winding ice tongue of Illinoian age extended from the east lobe down the valleys of the Great Miami and Ohio Rivers almost to the present mouth of the Kentucky River. The magnitude of this extraordinary ice tongue makes it a feature unique along the margins of the great ice sheets that invaded central United States. Although no data are available on which to base age differentiation of the two lobes in Ohio and Indiana, it is assumed that the lobes were penecontemporaneous and that the ice tongue formed at the time of maximum advance of the east lobe and was presumably of short duration.

Illinoian glacial deposits are distinguished in the field by their topographic position, by their modest weathering profiles compared with profiles on Kansan and Nebraskan deposits, and in places by their surficial moraines, a feature not characteristic of the older glacial deposits. In Clermont and adjacent counties in southwest Ohio, till of Illinoian age is widespread along the Glaciated Ohio River valley (pl. 1; Goldthwait and others, 1961). It is relatively thin, is normally leached of its primary carbonates to depths of nearly 10 feet, has a flat to undulating, somewhat poorly drained surface, and is present on the uplands as well as in the "Deep Stage" bedrock valleys. Durrell (1961) named this area of surficial Illinoian drift the Clermont Lobe, and described low northwest-trending morainic ridges east of Cincinnati. He pointed out that small tributaries to the Little Miami River tend to be parallel as they follow the shallow swales between the morainic ridges. To the south and east, the trend of these ridges swings to an almost east-west orientation, generally parallel to the valley of the Ohio River along the south margin of the Clermont lobe.

When the ice sheet of Illinoian age moved from the northeast into the region of the Glaciated Ohio River valley, the terrain, as a result of erosion, had attained the maximum relief that it was to attain during Quaternary time. This relief exerted a powerful influence over the movement of the ice, especially along its outer margin, where it was presumably thinner and its forward movement was less vigorous. Thus, terrain became important in determining the local as well as regional configuration of the ice front. In the Cincinnati 
region and along the glaciated valley of the Ohio River, the influence of the terrain is especially well demonstrated. The ice sheet, moving southwest in Clermont County, Ohio, essentially normal to the deep valley of the Ohio River, pushed into and across that valley and moved briefly for a short distance up into the hill lands of Kentucky before finally coming to a halt ( $\mathrm{pl}$. 1). To the south and east, where the Ohio River valley was roughly parallel to the direction of ice movement, the glacier seemingly was not able to cross the valley; it was halted and an equilibrium established through melting of the ice sheet by the swollen torrents carried by the river along the ice margin. In a few places, however, small tongues of ice apparently were able to span the river briefly, for, as noted by Leverett $(1902,1929)$, several isolated patches of till are present on the south side of the Ohio River valley upstream from that sector referred to here as the Glaciated Ohio River valley.

As the Illinoian ice sheet moved from the northeast into the vicinity of present downtown Cincinnati, it was impeded by the deep valley then followed by the northflowing Licking River, and the uplands to the west were not overridden by the ice. Farther to the north, however, the ice was channelled into the broad, deep valley of the southwest-flowing Great Miami River (pl. 1). Here, as along the Licking River, the steep walls confined the ice and inhibited widespread overtopping of the west valley wall, thereby hindering an advance of the ice across the Dearborn upland of southeast Indiana. The Great Miami River valley, because of its depth, width, and direction, provided an ideal chute for diverting and channelling the ice flow to and down the Ohio River valley to the southwest. So effective was this chute for the ice sheet, that the ice was concentrated into a tongue that followed the broad valley now largely occupied by the Great Miami River to its junction with the present Ohio valley and down that valley for about 50 miles, almost to the mouth of the Kentucky River (pl. 1). Durrell (1961; see also Ray, 1965b, c) recognized an ice tongue in southwest Ohio, his Harrison Lobe, and conservatively suggested that it extended from the Great Miami valley into the Ohio valley for about 10 miles. This ice tongue, unique in size along the margins of the vast ice sheets of North America, left many traces of its presence in the form of isolated drift deposits within the deep pre-Illinoian bedrock valley of the Ohio River.

Isolated deposits of stony or clayey drift within the bedrock valley of the Ohio River were described by Leverett $(1902,1929)$, who assigned to them an Illinoian age. He likewise cautiously assigned an Illinoian age to the more deeply weathered drift deposits in the abandoned high-level valleys on the uplands and to the deposits on the adjacent uplands into which the Ohio River valley had been cut about 500 feet. Although he suggested that the deposits in the abandoned valleys and on the uplands "seem likely to antedate the Illinoian stage of glaciation" (1929, p. 53-54), he appears to have assumed, without stating positively, that those deposits and the deposits within the Ohio valley were all the same age and were presumably deposited by the same ice sheet. This assumption is, of course, not tenable.

Examination of the deposits within the Ohio River valley indicates that there are five undoubted till deposits between the mouth of the Great Miami River and the massive deposit of Illinoian till immediately above Carrollton, Ky. (pl. 1; Ray, 1965b, c); several more deposits are questionable only because of the lack of suitable exposures to indicate that they have cores of Illinoian till.

The two masses of till of greatest interest, the "Split Rock conglomerate" at the mouth of Woolper Creek and the deposits near Carrollton, Ky., will be described later, after the general setting of the glacial deposits within the valley has been reviewed. To be described first are four masses of well-preserved glacial till on the inside of bends in the river valley downstream from the points of greatest curvature (figs. 12-15). Such deposition and preservation is expectable if the till was deposited from a narrow ice tongue moving down the sinuous, deep, and narrow valley of the Ohio River, for in such locations, till, intermixed with fluvioglacial masses, would be deposited and protected from removal by ice scour. In general, the deposits are similar to those found along the courses of sinuous valley glaciers.

Unfortunately, in the till masses preserved immediately below the bends of the present river valley, exposures are confined largely to shallow ditches and roadcuts that are only temporarily available for study. Furthermore, younger loess and dune sand of Wisconsin age may blanket the deposits, and few streams have cut valleys that reveal the nature of the underlying material other than by the float along their courses. The hummocky surface of the deposits does, however, contrast sharply with the relatively flat surface of the younger outwash terraces along the Ohio River valley that abut against and in places surround and overlap the lower parts of the deposits of Illinoian drift. Likewise, the relatively smooth trimmed steep slopes of the bedrock valley walls are readily differentiated in the field and on topographic maps from the hummocky surface of the unconsolidated glacial till deposited along their bases (figs. 12-15). The best exposure of till examined within the valley (1960) was in a cut along a secondary road through the till mass backing Egypt Bottom, about 400 feet north of Indiana State Highway 156 (fig. 15). Here, almost 5 feet of weathered brown clayey till containing much siliceous insoluble material and partially decomposed crystalline rock fragments was present im- 


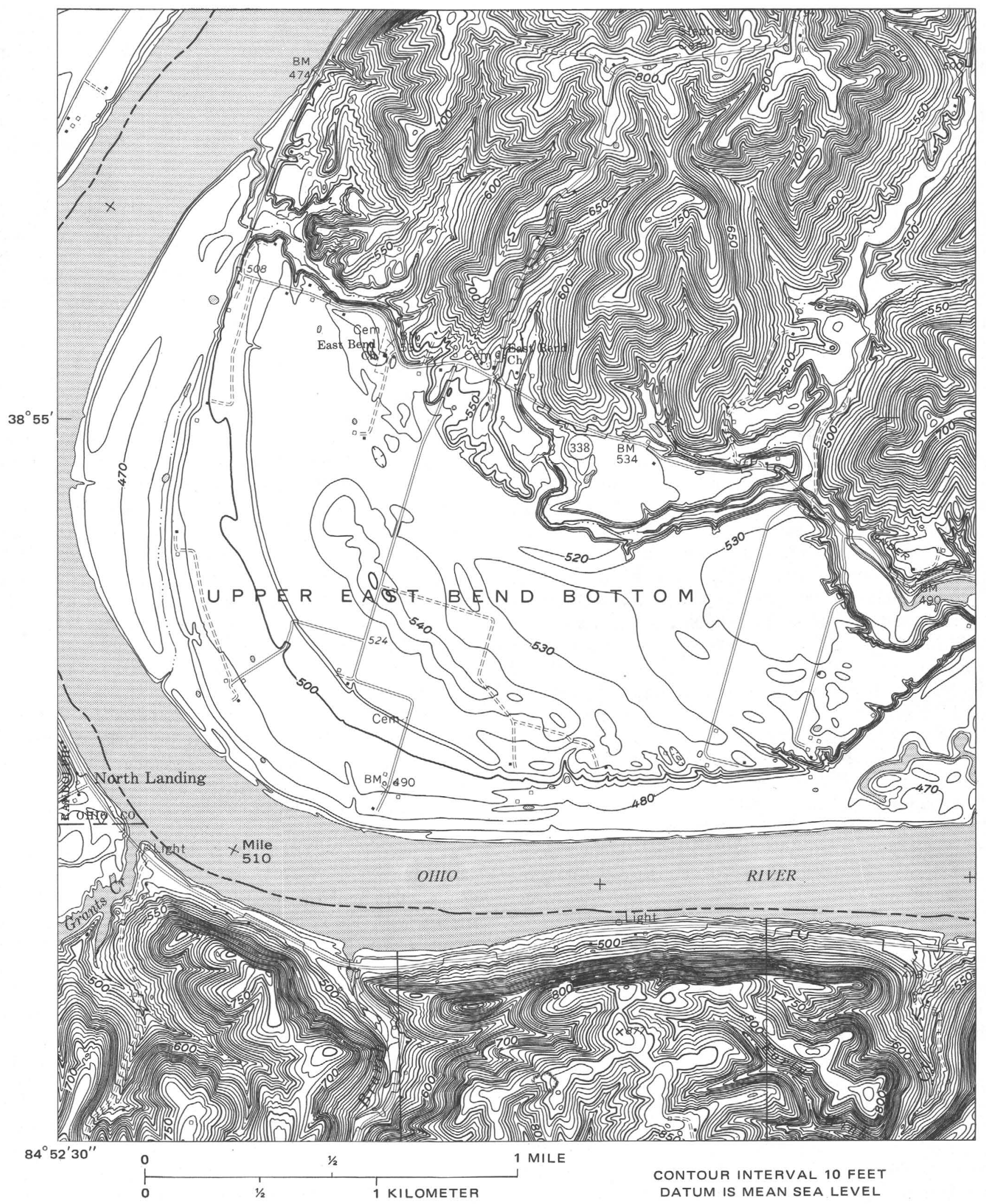

FiguRE 12.-Irregular mass of glacial drift of Illinoian age between sand-dune-mantled alluvium of highest terrace of Tazewell age at Upper East Bend Bottom and bedrock wall of Ohio River valley. The glacial drift has a characteristic dissected topography rising to an altitude of 580 feet. From U.S. Geological Survey Rising Sun, Ky. - Ind., 1961, 71/2-minute quadrangle. 
$84^{\circ} 47^{\prime} 50^{\prime \prime}$

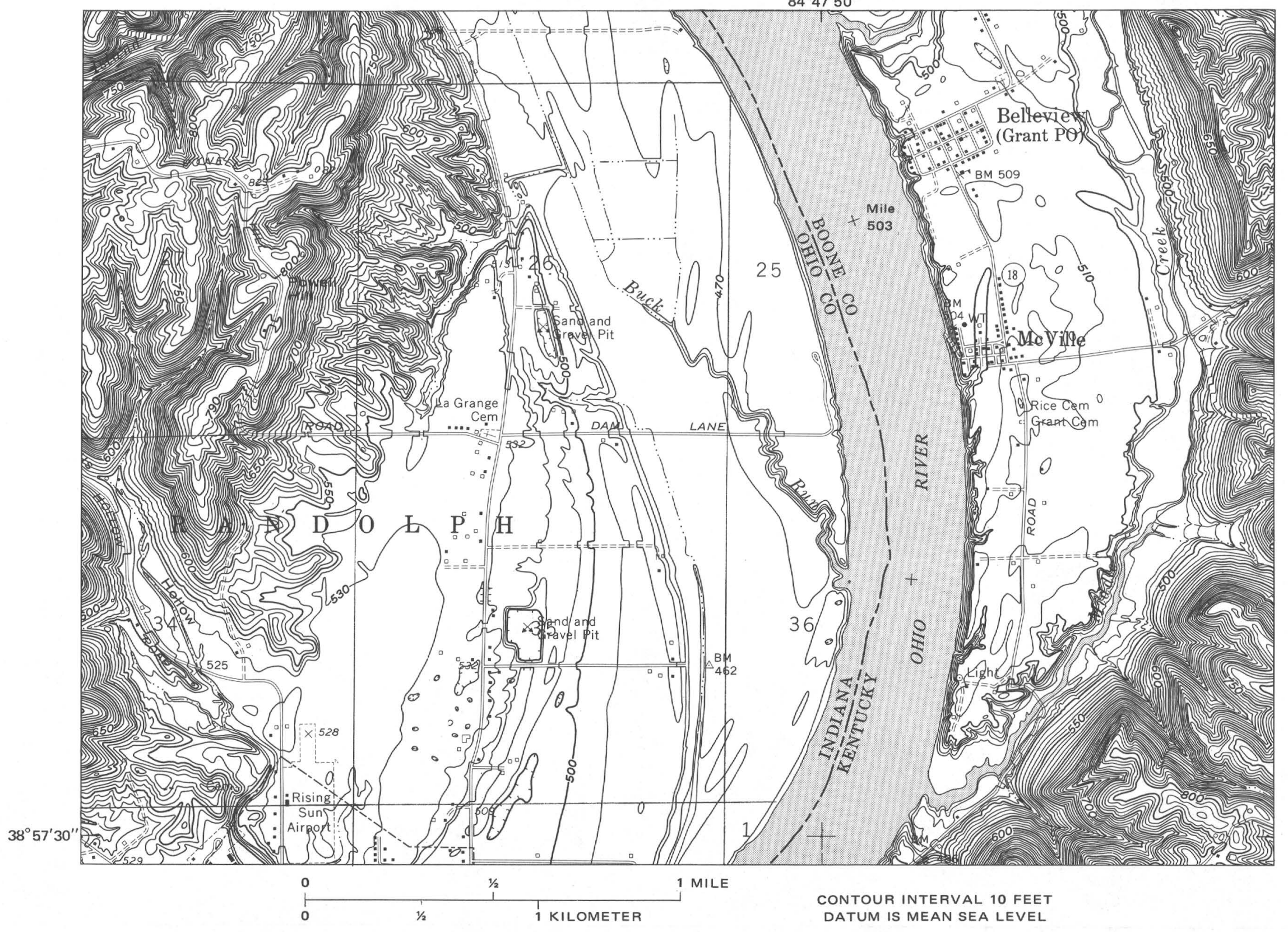

FIGURE 13.-Glacial drift of Illinoian age above alluvial terraces and flood plain of point bar north of Rising Sun, Ind. Characteristic dissected topography can be seen on drift along base of west bedrock valley wall. From U.S. Geological Survey Rising Sun, Ky.-Ind., 1961,. 71/2_minute quadrangle. 


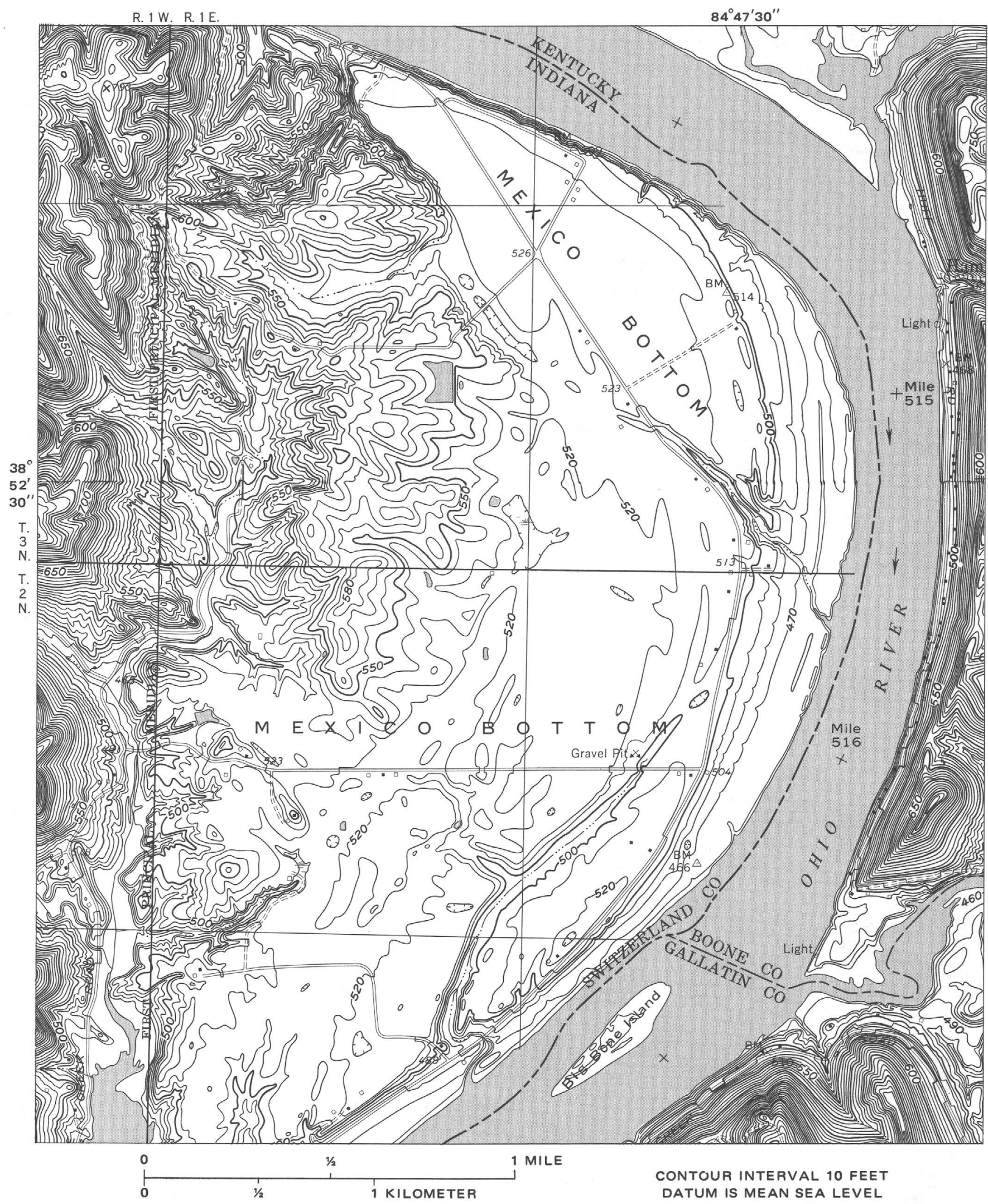

FIgURE 14.-Glacial drift of Illinoian age along bedrock west valley wall of Ohio River. The glacial drift rises above sand-dune-mantled alluvial terrace of Tazewell age at Mexico Bottom point bar to an altitude of 600 feet. From U.S. Geological Survey Rising Sun, Ky.Ind., 1961, and Patriot, Ky.-Ind., 1961, 71/2-minute quadrangle. 
R. IW.

R. 1 E.

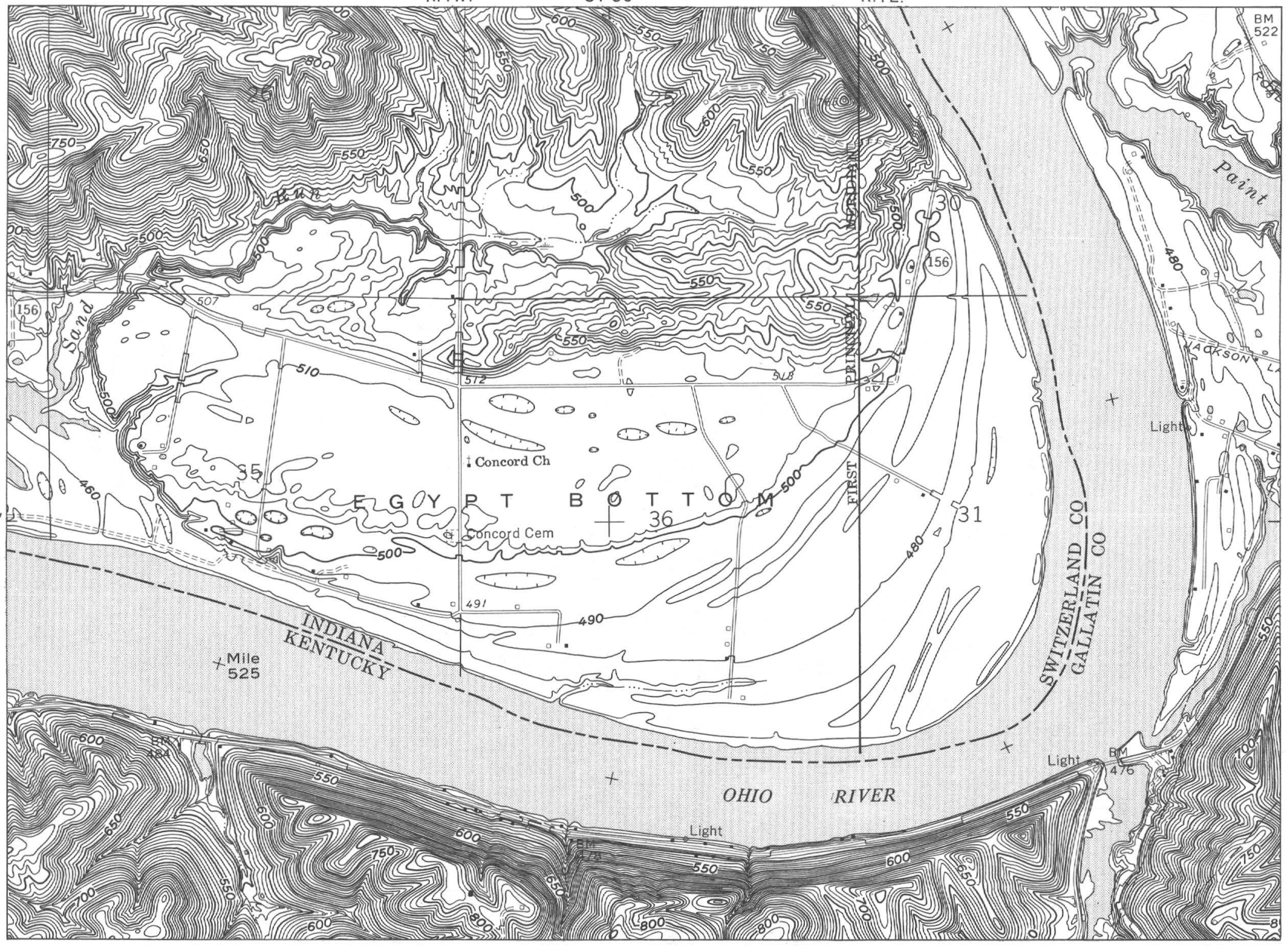

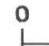

$1 / 2$

1 KILOMETER

1 MILE

CONTOUR INTERVAL 10 FEET

DATUM IS MEAN SEA LEVEL

Figure 15.-Glacial drift mantled by loess and dune sand forms a distinct ridge between Sand Run and dune-mantled terrace of Tazewell age on north side of Ohio River valley at Egypt Bottom. Uplands rise more than $200 \mathrm{ft}$ above the highest loess-mantled glacial drift. From U.S. Geological Survey Patriot, Ky.-Ind., 1961, 71/2-minute quadrangle. 
mediately below about 18 feet of leached loess and dune sand. Slumping of the sand and silt prevented detailed sectioning.

Suspected glacial till is difficult to identify with certainty where there are no. outcrops, where float of crystalline rock is missing, and where the characteristic hummocky terrain is poorly developed, although the deposits are in protected topographic positions relative to the bedrock valley walls. Glacial deposits of this category have been found (1) adjacent to the point where the valley of Middle Creek joins that of the Ohio (Lawrenceburg quad., Kentucky-Indiana-Ohio; Leverett, 1929); (2) at the head of Steele Bottom (Patriot quad., Kentucky-Indiana); (3) at the head of an unnamed "bottom" in Kentucky near Mile 526 (Patriot quad., Kentucky-Indiana); (4) at the foot of the bedrock valley wall along Long Lick Creek west of Florence, Ind. (Florence quad., Indiana-Kentucky); and (5) south of U.S. Highway 42 and east of Stephens Creek south of the Markland Locks and Dam on the Ohio River (Florence quad., Indiana-Kentucky).

Elsewhere along the Ohio River the writer believes that in places tributary valleys were so oriented in relation to the downvalley movement of the ice tongue that small distributary tongues were pushed from the main ice tongue into the lower parts of the tributary valleys, where small masses of till were deposited. This would explain the small mass of glacial till in the col between two unnamed small creeks along State Road 338, about 0.85 mile northeast of the village of Big Bone, Ky. (Rising Sun quad., Kentucky-Indiana). Here, weathered till is exposed along the road at an altitude near 580 feet, which is about 250 feet below the dissected upland surface and 150 feet above the level of the nearby Ohio River. For this till to have been deposited by a distributary tongue of Illinoian age would have required an ice tongue about $1 \frac{1 / 4}{4}$ miles long extending from the main ice mass. At this locality, the till contains mostly sedimentary rock fragments but has a few scattered crystalline cobbles; a single 5-inch-diameter rough fragment of clear vein quartz, collected by the writer, is as far as known, unique from the glacial drift of Kentucky.

Other creek valleys that may have been invaded by distributary ice tongues are Sugar and Little Sugar Creeks in Kentucky (Patriot quad., Kentucky-Indiana) and a small tributary to Craigs Creek from the hills of Kentucky near Mile 530 (Florence quad., IndianaKentucky). Detailed mapping may reveal residual deposits elsewhere.

A heterogeneous mass of poorly graded and cemented particles, largely of limestone and crystalline rock, constitutes the locally well known "Split Rock conglomerate" (p. 37) that is present above and below the mouth of Woolper Creek between the bank of the
Ohio River and the bedrock valley wall (pl. 2C). Long the subject of local interest and speculation by Locke (1845), Sutton $(1877,1879)$, Leverett $(1902,1929)$, Fowke (1933), and Durrell (1956), the "Split Rock conglomerate" is here interpreted to be a kame terrace of intermixed glacial outwash and till accumulated within the valley of the Ohio River immediately below the mouth of a short now-abandoned valley that once served as a marginal sluiceway for melt-water torrents and debris from the Illinoian ice (pl. 2C). The outwash was deposited by the melt-water torrents between the bedrock wall of the Ohio River valley and the ice tongue that occupied the river valley and that was the source of the till.

The accumulated mass of glacial outwash and till, now mantled by Wisconsin silt and dune sand, has a nearly flat surface at somewhat more than 150 feet above the present pool stage of the Ohio River. It occupies an area of possibly 1.5 square miles and extends back from the riverbank for almost a mile to the bedrock valley wall. The deposit is composed of particles from clay to boulder size, in places crudely intermixed and in places well graded; it commonly has an open texture. In general, the materials are well cemented as a result of solution and redeposition of calcite derived from the included limestones, which form the largest part of the mass.

The conglomerate is best exposed in the bluffs along the Ohio River above the mouth of Woolper Creek. There, about 30 to 40 feet of rugged conglomerate rise from the level of the river. Downstream from the mouth of Woolper Creek and in the walls of small valleys tributary to Steep Creek (pl. 2C), remarkably fresh bluegray calcareous outwash and till are exposed. Till is locally present above and below the glaciofluviatile sand and gravel.

The history of the kame terrace at the mouth of Woolper Creek and the relationship of the terrace to the abandoned valley east of Petersburg, $\mathrm{Ky}$., and to the Great Miami and Ohio River valleys provide the best information on the head of the ice tongue of Illinoian age.

The approximate downvalley limit of the ice tongue is believed to be marked by the mass of till along the south wall of the Ohio River valley immediately above Carrollton, Ky. (pl. 2B). This till mass is, however, not in the main valley of the Ohio River but has been pushed from that valley across a low col into an abandoned meander channel in the lower valley of the Kentucky River. The till has a hummocky, morainelike surface which rises some 170 feet above the pool stage of the nearby Ohio River and about 100 feet above the highest glaciofluvial terrace of Wisconsin age which overlaps the outer margin of the till in the Kentucky River valley. Leverett $(1902,1929)$ noted that this mass is "a heavy 
deposit of Illinoian drift***of clayey till, and***numerous striated stones" (1929, p. 53).

In preglacial time the Kentucky River followed a highlevel channel that joined the channel of the present Ohio River at a point about 3.5 miles upstream from the Carrollton area (fig. 10). This ancient high-level channel was disrupted and abandoned as a result of modifications during Nebraskan time. After this abandonment and prior to the "Deep Stage" erosion during Yarmouth time, the present broadly meandering lower Kentucky River valley came into being. Both the Kentucky and the Ohio Rivers were actively engaged in downcutting and widening their valleys. As the south wall of the Ohio was eroded back during valley widening, it intersected the north wall of a great meander scar of the lower Kentucky River to form a bedrock col at the point of intersection (pl. $2 B$ ). Although evidence is not available to provide information on the subsurface configuration of the bedrock at the col, the divide between the two valleys was presumably not wholly removed at depth, for there is no evidence that the col has ever served as a drainageway connecting the two valleys. Furthermore, evidence for a bedrock meander core, such as that at Bunker Hill (Leverett, 1929, fig. 8), a few miles up the Kentucky River valley, is lacking. However, remnants of such a meander core may be buried and preserved beneath the alluvial deposits of Wisconsin age immediately south of the col (pl. $2 B$ ). Precise interpretations await specific data.

The fact that till unrelated to that on the uplands is present within the bedrock Ohio River valley between the mouths of the Great Miami and Kentucky Rivers (pl. 1) can be explained only on the basis of deposition from a long sinuous ice tongue younger than the ice sheets of Nebraskan and Kansan age which deposited till on the adjacent uplands. The fact that these upland tills are deeply weathered, whereas the till within the valley is relatively little weathered, aids in the assignment of an Illinoian age to the deposits within the valley. Furthermore, as pointed out by Rich (1956), the valley walls give no hint of a direct connection between tills on the uplands and deposits within the valley; the deposits are separated in time of deposition by a major interval of erosion, the Yarmouth time. Thus, topographic position, depth of weathering, and surface configuration of the till within the Ohio River valley lead to the conclusion that the till was deposited by an ice tongue of Illinoian age.

The lack of loess deposits that can be assigned an Illinoian age along the Glaciated Ohio River valley above the Carrollton area substantiates the belief in the presence of an ice tongue within the valley, for an ice tongue would have been an inhibiting factor in the formation of loess. If a normal valley train had occupied the valley in that area, its depositional surface would have served as a source area for limited loessial sediments (Ray, 1965a), even though the valley was not suitably oriented and was too deep and narrow to offer optimal conditions for deflation of sediments. On the other hand, because an ice tongue occupied the valley, no source area for loessial sediments existed, and loess was only deposited farther down the valley, beyond the limits of the ice tongue. Loess of Illinoian age is first present (Ray, 1957, 1965a) only downstream from the terminus of the ice tongue, in the Glaciated Ohio River valley sector near Goshen, Ky. (Owen quad., KentuckyIndiana). There, lower valley walls permitted strong northwest winds to transport and deposit loessial silt and clay particles derived from the valley-train surface beyond the limit of the ice tongue.

West of the valley of the Great Miami and Whitewater Rivers, the boundary of the ice sheet of Illinoian age is obscured and not known because it is covered by overlapping deposits of Wisconsin age. Field investigations have led to the interpretation that only drift of Kansan age appears south of the well-defined boundary of the Wisconsin glacial drift to a point where the drift of Illinoian age appears in southwest Bartholomew County, Ind., as part of the Jackson lobe (pl. 1). There, the boundary between the surficial Kansan till on the east and the Illinoian till on the west is poorly defined except where marked by the massive Chestnut Ridge and the smaller, less continuous Tampico Ridge. In general, the pre-Wisconsin glacial deposits are either removed or buried by glacial outwash and valley train along the East Fork of White River and the Muscatatuck River, especially in the area of the Scottsburg lowland.

Chestnut Ridge, a prominent topographic feature, was first described as a moraine by Cox (1879). Later, Leverett (1902, p. 256) pointed out that there was "little question that the ridge should be classed as a moraine" and, furthermore, that wells penetrating Chestnut Ridge passed through glacial drift to a point "fully 50 feet below the base of the ridge," that is, below the outwash plains and lacustrine flats of Wisconsin age that surround Chestnut Ridge. Although outcrops are now limited to shallow roadside exposures, the ridge appears to be composed of drift with weathering profiles reminiscent of those on the Illinoian drift within the Ohio River valley. Strangely, both Cox and Leverett failed to suggest the direction of ice movement that built the moraine. Leverett $(1902$, p. 256$)$ simply noted that Chestnut Ridge "is not at the extreme limits of the drift, there being a plain west of it a few miles in width which is underlain by clay and sand carrying glacial pebbles." Glacial deposits surround the moraine (Wayne, 1958), but they have not been separated accord- 
ing to age. Only ambiguous statements concerning the age of the moraine have been made; for example, Leverett (1902, p. 256) suggested only that the moraine should "be considered in connection with the drift border, since it is not unlikely that the ice sheet formed this ridge while it was still occupying neighboring parts of the drift border." The only rational explanation is that the ridge is a terminal moraine of Illinoian age that bounds the Jackson lobe to the west and separates it from drift of Kansan age to the east.

Rising to a maximum of 150 feet above the surrounding areas of glacial outwash of Wisconsin age, the irregular hummocky Chestnut Ridge extends as an almost continuous ridge from near New Farmington (Chestnut Ridge quad., Indiana) to the southwest (Seymour and Tampico quads., Indiana) for about 8 miles. The main ridge, generally less than half a mile wide, has a maximum width of near $1^{1 / 4}$ miles. Its eastern, or outer, margin is relatively regular, in contrast to its inner margin, which is highly irregular and has small scattered elongate knolls and hills that parallel the trend of the main ridge and are in part surrounded by fluvioglacial deposits of Wisconsin age. These small knolls and hills are interpreted as fragments of discontinuous retreatal morainic deposits. From the southern terminus of Chestnut Ridge, a small and irregular ridge continues for nearly 4 miles to the southwest, passing northwest of the village of Tampico. It is here named Tampico Ridge and is defined as a retreatal moraine of Illinoian age.

Outwash of Wisconsin age in the broad valleys of the Muscatatuck River and East Fork of White River obscures the details of the boundary of the ice sheet of Illinoian age. Proglacial ice-margin drainage in Illinoian time probably occupied these same channels and may have effectively halted the advance of the ice to the south along the base of the Knobstone-Muldraugh Hill escarpment. No evidence has been found to suggest that in this area the ice sheet of Illinoian age crossed the Muscatatuck River. All glacial melt waters east to the Whitewater River drainage appear to have been funnelled through the gorge to the west and not along the Scottsburg lowland to the Ohio valley.

Malott (1922) called attention to a deposit well beyond the boundary of the Illinoian ice sheet as marked by the Chestnut Ridge-Tampico Ridge morainic complex. The deposit lay near the mouth of the Muscatatuck River in the vicinity of the Millport Knobs, along the bluff marking the south valley wall of the Muscatatuck River (Vallonia quad., Indiana). It consisted of a gravel deposit, presumably of Wisconsin age, underlain by deeply weathered till in which large crystalline boulders were rotted to their centers. Following Leverett's belief that the oldest till in the region was of Illinoian age,
Malott (1922, p. 144) reported that "the till, while having the appearance of being much older than the Illinois till, has been correlated with the Illinoian stage." The present study indicates that Malott's observations were correct but that his interpretation was incorrect and that the deeply weathered till is of Kansan age and the overlying gravel outwash is possibly of Illinoian age and derived from the nearby ice sheet. Unfortunately, Malott's locality could not be found during field studies in the area.

The interpretation of the spatial distribution of the tills of Kansan and Illinoian age here presented is based on field observations of topographic position, relative depth of weathering, and, in places, surface expression. When, however, an attempt is made to correlate the age of the tills on the basis of the average depth of leaching of the primary carbonates in the deposits, many difficulties arise. These difficulties are attributed to several factors that affect the depth of leaching, such as (1) a mantling deposit of loess, dune sand, or gumbolike clay overlying the till; (2) local topographic conditions that affect both external and internal drainage and the rate of surficial erosion; (3) till composition and porosity; (4) ground-water conditions; (5) thickness of the deposits; and (6) possible minor climatic differences. With so many variables, precise correlations between regions made on the basis of depth of carbonate leaching are not only hazardous but perhaps unreliable. Flint (1949) pointed out, however, that although intrastadial correlations based on depth of leaching may be unreliable, stadial correlations may be valid.

Published data on the depth of leaching of till identified as Illinoian in age in the vicinity of the Glaciated Ohio River valley are not consistent and do not agree with data on average depth of leaching determined by field studies in adjacent areas. In the Cincinnati area, Durrell (1961, p. 56) reported that "where the till (Illinoian) is deeper than the depth of leaching, it is leached 6 to 8 feet." East of Cincinnati, in Clermont County, Ohio (pl. 1), the reported maximum depth of leaching of soils formed on the Illinoian till averages about 10 feet (Taylor and others, 1923). In contrast, in southeast Indiana, Thornbury (1937) reported the average depth of leaching of the Illinoian till to be 147 inches (12 ft, $3 \mathrm{in}$.), a figure comparable with the 12 -foot average depth of leaching reported by Durrell (1961, p. 56 , fig. 6) for till he identified as Kansan in the Cincinnati area. This lack of uniformity in the observed average depths of leaching eliminates depth of leaching as an infallible basis for stadial correlation of till sheets unless the data are interpreted on the basis of local environmental influences. In southeast Indiana, the writer believes that an average depth of leaching of 12 feet or more, when combined with other factors (especially the 
position of the till as related to the dissected terrain), indicates that the till is of Kansan rather than Illinoian age and is correlative with similarly leached till identified as Kansan by Durrell in the Cincinnati area.

\section{DRAINAGE MODIFICATIONS RESULTING FROM THE ILLINOIAN GLACIATION}

The advance of the ice sheet of Illinoian age into the drainage basin of the Ohio River resulted in the last of the major Quaternary drainage modifications along the river valley and in the development of the present course of the Ohio in the Cincinnati area. At its maximum extent, the ice sheet in places crossed and temporarily ponded the river, forcing water to overtop low drainage divides, or cols, and form new channelways. The most important drainage change was the abandonment of the great northern loop of the river around the Cincinnati area as the channel of the main stem of the Ohio River.

The Clermont lobe of the ice sheet, because of its position relative to the presumed source area to the northeast, is believed to have reached southwest Ohio before the Jackson lobe reached south-central Indiana. Undoubtedly, long before the ice sheet had advanced far to the southwest, it reached into the drainage basin of the Ohio in northwest Pennsylvania and northeast Ohio, pouring vast quantities of melt water and glaciofluvial debris into tributaries of the main stem of the river. At this time, drainage to the Gulf of Mexico was unimpeded; not until the ice sheet had advanced into the Cincinnati area was drainage along the river interrupted and, as a result, modified through a series of complex drainage changes.

Before attempting to recount these drainage changes in sequence, it is wise to review briefly the drainage pattern in the Cincinnati area immediately before its disruption by the ice sheet of Illinoian age. The broad valleys abandoned by major streams or containing underfit streams, and the steep-walled narrow gorgelike valleys almost lacking in flood plains, have long attracted attention (James, 1888; Fowke, 1898, 1900, 1933; Fenneman, 1916; Durrell, 1961). The general belief is accepted that disruption of drainage by the glacier caused ponding of the streams until erosion by impounded waters pouring across low cols in the easily erodible thinly bedded limestones could permanently alter the drainage pattern in a manner similar to that used to explain the present channels across the preglacial Manchester and Madison divides. Some elaboration in the sequential history of the drainage modifications and some changes in the timing of events are herein suggested as the result of the recognition of a more complex history of glaciation for the Cincinnati area than has been previously reported.

Above the mouth of the present Little Miami valley, the drainage basin of the Ohio had essentially assumed its present configuration by the beginning of Illinoian time and "Deep Stage" stream erosion had so entrenched the bedrock valleys that relief was somewhat greater than that of today, for the valleys have been subsequently filled with thick alluvial deposits. To the northwest, the main stem of the Ohio encircled the present-day Cincinnati area in a great loop that followed the broad valley of the old Manchester River to the vicinity of Hamilton, Ohio, and thence to the southwest, down the broad valley of the old Cincinnati (Hamilton) River, to the present Ohio valley at Lawrenceburg, Ind. (fig. 6).

When the ice sheet of Illinoian age advanced into the Cincinnati area, no through valley followed the course of the present Ohio River between the mouths of the Little Miami River on the east and the Great Miami River on the west. As a result, the uplands of northern Kentucky extended almost uninterruptedly northward to the ancient encircling river valley (fig. 16). This northern extension of the uplands of Kentucky was divided by the north-flowing Licking River into two upland prongs of unequal size - a small east prong, here termed the Walnut Hills prong, between the Licking River valley and the encircling Manchester River valley to the east, and a larger west prong, here termed the Cheviot prong, between the Licking valley and the encircling (ancient

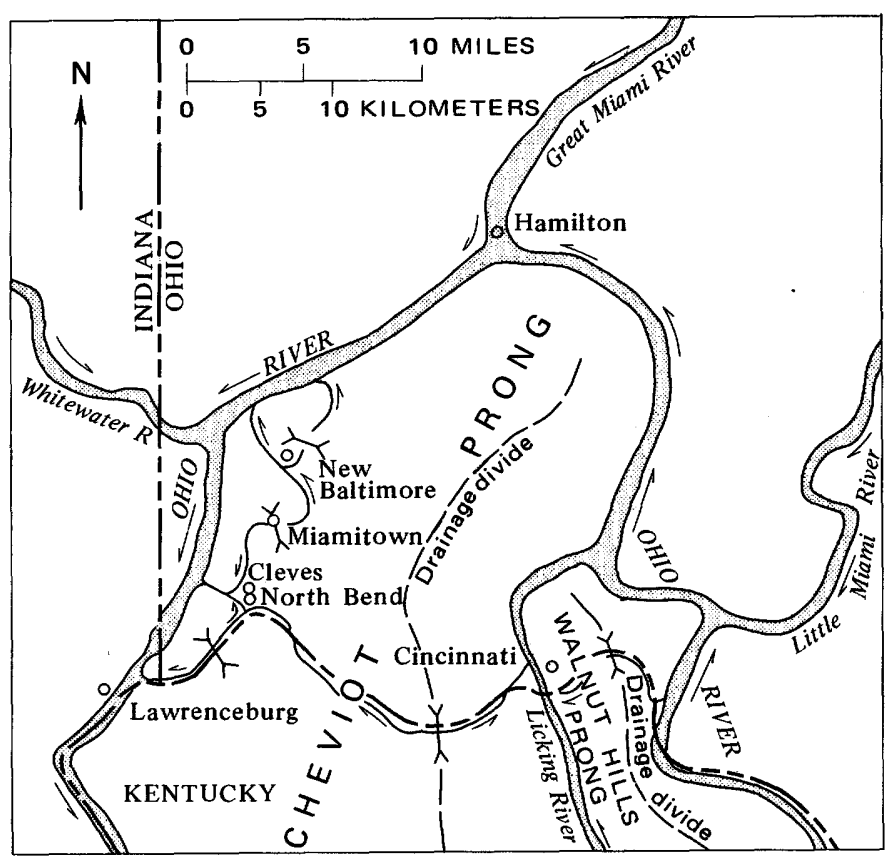

Figure 16.-Main drainage channels of the Cincinnati region immediately before invasion by the glacier of Illinoian age. Note the drainage divides that were overtopped and destroyed during the glaciation of Illinoian age, thereby producing the present channels of the Ohio and Great Miami Rivers. Compare with figure 17. 
Cincinnati) river valley to the west. Small tributaries of both the Licking valley and the major encircling valley were engaged in vigorous erosion of the old driftmantled upland prongs and in downcutting their steeply graded and entrenched valleys to the level of the "Deep Stage" of the main valleys, a level attained mainly in pre-Illinoian (Yarmouth) time.

North-south drainage divides along the spine of each prong separated drainage to the encircling river from that to the Licking River (fig. 16). On the Walnut Hills prong, the divide crossed the site of the present Ohio River between Miles 467 and 468 (Newport quad., Kentucky-Ohio); the divide on the Cheviot prong crossed the present Ohio River between Miles 476 and 477 (Covington quad., Kentucky-Ohio). These divides, almost coincident with those proposed by Fenneman (1916), have been determined primarily on the basis of (1) the present-day continuation of the old drainage divides across the Ohio valley, (2) the expectable normal confluence of the small tributary streams with the present Ohio River downstream from the divides, (3) the barbed confluence of the tributaries upstream from the divides, and (4) the character of the Ohio valley walls adjacent to the divides.

The presence of these divides across the present Ohio River valley is most important in the interpretation of the drainage of the main stem of the Ohio River that has resulted from the invasion of the area first by the Kansan ice sheet and later by the Illinoian ice sheet. These invasions, especially the Illinoian, resulted in the destruction of the great northern loop. Where each divide crossed the present Ohio valley, a col has been postulated (Fenneman, 1916; Fowke, 1933; Durrell, 1961). Headward erosion from a common point on the divide by small streams flowing in opposite directions produced each col. Thus, the low col on the Walnut Hills divide was produced by two short streams-one flowing to the encircling river valley on the east, the other to the old Licking River valley on the west. Similarly, two streams headed in the col on the Cheviot divide; one flowed northeast to the old Licking River valley, and the other, much longer, flowed northwest in a somewhat sinuous course to join the encircling pre-Illinoian river that flowed down the broad, deep, lower valley of the present Great Miami River (fig. 16).

In pre-Illinoian (Yarmouth) time, a small stream appears to have followed the course of the present Ohio River from a col in the divide on the Cheviot prong to the vicinity of North Bend (fig. 16). Presumably the stream was a headwater branch of Dry Creek (Covington quad., Kentucky-Ohio). West of the col area, the stream appears to have joined conformably Elijahs Creek, a major tributary from the south, and Rapid and Muddy Creeks, tributaries from the north (Burlington quad.,
Kentucky-Ohio; Addyston quad., Ohio-Kentucky; and Hooven quad., Ohio-Indiana-Kentucky). At North Bend, the pre-Illinoian stream turned abruptly north, passing through a gorgelike "Deep Stage" bedrock channel to the vicinity of Cleves. Fowke (1933) recounted the discovery of this till-blocked channel during operations preparatory to the drilling of a railroad tunnel through the presumed bedrock ridge that now separates the present Ohio and Great Miami River valleys. From Cleves, the pre-Illinoian stream flowed west to join the main stem of the encircling river south of the present confluence of the Whitewater and Great Miami Rivers.

Before the invasion of the region by the Illinoian ice sheet, the course of the master drainage stream from the apex of the loop encircling the Cincinnati area to the main valley of the present Ohio near Lawrenceburg, Ind., followed only in part the course of the major drainage stream of today, the Great Miami River (fig. 16). Furthermore, the present Ohio River valley between North Bend and the mouth of the present Great Miami River (Hooven quad., Ohio-Indina-Kentucky, and Lawrenceburg quad., Kentucky-Indiana-Ohio) was not through-flowing but consisted of the valleys of two small streams draining in opposite directions from a col along a minor divide near.Mile 489 on the present Ohio, as indicated primarily by the normal and the barbed confluence of the small tributaries to the present river on either side of the postulated divide. One stream presumably flowed northeast from the col and was

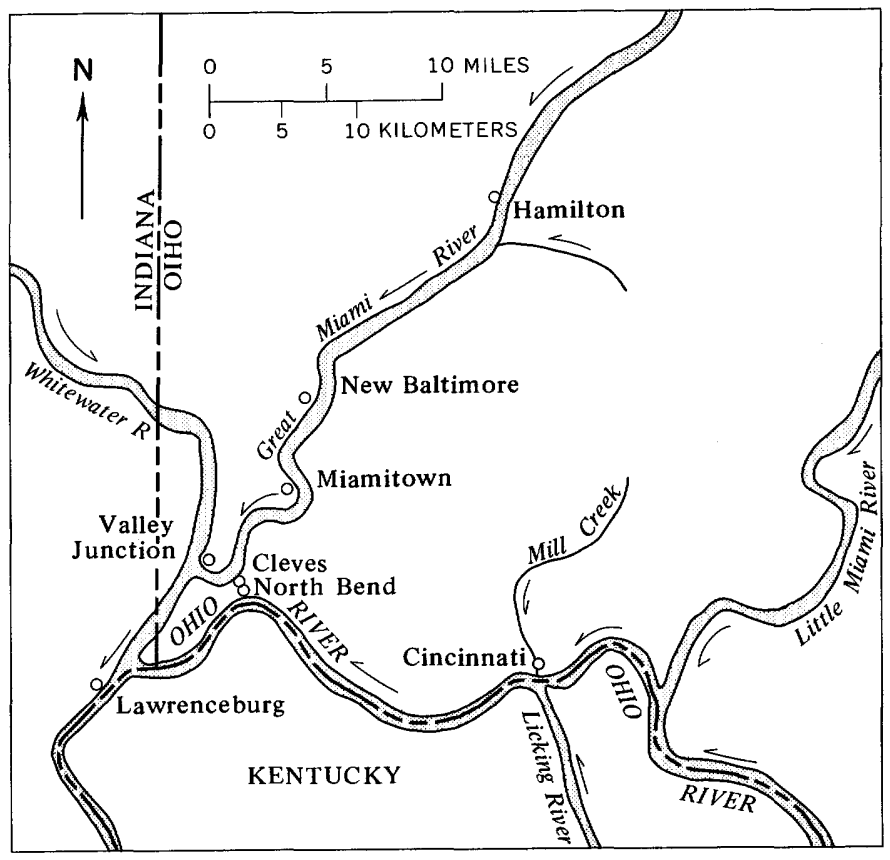

FiguRE 17.-Main drainage channels of the Cincinnati region after the Illinoian Glaciation and the final integration of streams into the present drainage pattern. 
tributary to the drainage through the bedrock gorge at North Bend; the other stream flowed southwest, toward the confluence of the present Great Miami and Ohio Rivers, and was tributary to the main drainage to the southwest.

The present course of the Great Miami River from Hamilton, Ohio (fig. 17), to its confluence with the present Ohio River follows in part the broad preglacial valley of the ancient north-flowing Cincinnati River of Tight (1903). After the pre-Illinoian ice sheets had reversed the drainage, this broad valley was occupied by the drainage of the Ohio River flowing to the southwest. Now choked with glacial drift, the broad valley is in places more than 2 miles wide and is drained only by small creeks and by the lower course of the Whitewater River, a tributary of the Great Miami. The Great Miami River flows, on the other hand, in a relatively narrow valley, in one place little more than a quarter of a mile wide. To understand the anomalous relationship of river to valley size that resulted from drainage modifications related to the invasion of the Illinoian ice sheet, the preIllinoian drainage pattern must be reviewed, for before Illinoian time, no through-flowing channel existed along the present narrow course of the Great Miami. Fenneman (1916) postulated that before the Illinoian ice advance, the lower course of the present Great Miami was represented by a short south-flowing stream that followed in general the present river course from a divide about 1 mile south of Miamitown to its junction with the present Whitewater River (Addyston quad., Ohio-Kentucky). This part of the valley is narrow, the tributaries are conformable, and the smooth, "ungrooved" valley walls have a youthful appearance similar to the valley wall along the present Ohio River in the vicinity of the divide on the Cheviot prong.

Evidence that the divide was south of Miamitown, as postulated by Fenneman (1916), is not convincing, for the drainage pattern of today indicates that the divide was more likely at Miamitown, as suggested by Fowke (1933), or even at a point about 2.5 miles north of Miamitown (Addyston quad., Ohio-Kentucky, and Shandon quad., Ohio). The character of the normal confluence of small tributary streams and of Taylor Creek with the present Great Miami leads to the belief that the divide was near Mount Hope Church, about 2.5 miles north of Miamitown. Fowke (1933) suggested that Taylor Creek was, before glacial modification, north flowing above a divide at Miamitown. However, the present interpretation suggests that a small headwater tributary to the preglacial Taylor Creek flowed south from the postulated divide at Mount Hope Church, north of Miamitown, to the confluence of the present Taylor Creek and the Great Miami River at Miamitown, and thence south along the course of the present Great
Miami River. Although Taylor Creek was the master drainage stream before glacial modification by the Illinoian ice sheet, it was the valley of the small headwater tributary, rather than the valley. of Taylor Creek above its confluent tributary, that provided the drainage channel now followed by the river. The situation is analogous to that of the present Ohio River west of the divide at Madison, Ind., where the Ohio flows today in a valley that was a small headwater tributary of the preglacial Salt River before glacial disruption of the drainage pattern.

If the divide was at Mount Hope Church, a short stream presumably flowed north from the divide for about 2 miles up the present Great Miami valley to be joined by another small southwest-flowing tributary before turning to the north, past Fernald, 1.5 miles northwest of New Baltimore (fig. 17), to join the major drainage in the broad pre-Illinoian valley that encircled the Cincinnati area (fig. 16). The short southwest-flowing tributary is believed to have headed in a low divide in the vicinity of New Baltimore. A small stream is postulated to have flowed north from the New Baltimore divide to join the major stream in the encircling major valley. Thus, where there is now a through-flowing stream, the Great Miami River, there were, before the disruption of the drainage by the Illinoian ice sheet, four small valleys separated by two low divides. Streams in these valleys were all tributary to the major river that flowed southwest through the broad valley encircling the Cincinnati area.

As the ice sheet of Illinoian age invaded the Cincinnati area from the northeast, it presumably overwhelmed first that part of the major preglacial north-flowing drainage, earlier referred to as the Manchester River channel, that formed part of the drainage around the Cincinnati area, from the vicinity of the mouth of the present Little Miami River to the vicinity of Hamilton, Ohio (fig. 16). As a result, the Ohio River above the mouth of the Little Miami, and its north-flowing tributary, the Licking River north of Cincinnati, were ponded. Normal drainage augmented by glacial meltwater torrents soon caused the ponded waters to overtop the low cols along the drainage divides on the Walnut Hills and Cheviot prongs, and the flow of the major drainage was established to the west through the gorgelike North Bend-Cleves channel. Both divides, it should be recalled, may have been temporarily used as overflow channels during Kansan time. Lacustrine deposits of Illinoian age deposited within the valley of the north-flowing Licking River, as well as other "Deep Stage" valleys, indicate that the river was indeed ponded (Fenneman, 1916; Durrell, 1961). The vigorous torrential flow across the low cols and the easily erodible flaggy limestone and shale bedrock led to such rapid downcut- 
ting of the cols that a new channel became permanently established from the mouth of the Little Miami River to the vicinity of North Bend-a section now used by the Ohio River (fig. 17).

Continued advance of the ice sheet in the Cincinnati area was inhibited by the high relief of the Cheviot prong (fig. 16), so only the northern part of the prong was ice covered (pl. 1). At the maximum advance of the ice, a small tongue extended a short way down the Licking valley and deposited till on the lacustrine beds (Fenneman, 1916; Durrell, 1961). To the southeast, the ice sheet was sufficiently vigorous to push briefly across the deep Ohio River valley, into the steep tributary valleys, and onto the hilly uplands between Silver Grove (Mile 460) and Mentor (Mile 445) for distances of as much as 4 miles (pl. 1; Newport and New Richmond quads., Kentucky-Ohio, and Withamsville quad., OhioKentucky). Because the main river channel was blocked for a time, drainage followed marginal bypass routes in the well-defined channelways along the valleys of Flagg Spring, Twelvemile, and Fourmile Creeks (Leverett, 1929). Although these creek valleys are relatively small, they were seemingly able to carry briefly the entire flow of the Ohio River above Mentor.

The most obvious bypass route, presumably used first, is that which follows Flagg Spring Creek from its former mouth near Mentor, to the northwest and across a low divide into the valley of Twelvemile Creek, a tributary to the Ohio near Mile 452. This 7-mile bypass along the river valley may have been used only briefly, for the mouth of the Flagg Spring Creek channelway at Mentor became drift filled at the same time the lower part of Twelvemile Creek may have been ice blocked by the advancing ice of the Clermont lobe. Both ends of the bypass route having been blocked, a new bypass channelway was initiated upstream from Mentor-from near Ivor, Ky., at Mile 443 to the point at Silver Grove where Fourmile Creek emerges from the hills near Mile 459 (Laurel and Moscow quads., Ohio-Kentucky).

The bypass channel from Ivor to Silver Grove follows, for about a mile, the upper part of the valley of Goose Creek, from a low col along the Ohio River valley wall to a low divide of similar altitude between the headwaters of Goose Creek and Flagg Spring Creek. It then follows Flagg Spring Creek past the drift-blocked mouth at Mentor, into the valley of Twelvemile Creek, and down that valley to the valley of a tributary from the north, Willow Branch, at Twelvemile Church. Following up Willow Branch to a low divide, the channel crosses into Fourmile Creek valley and follows that valley to its mouth at Silver Grove on the Ohio. Leverett (1929) called attention to the mass of glacial debris in the bottom of Twelvemile Creek valley at its junction with Willow Branch and to the coarse and poorly cemented conglomerates, composed of flaggy local limestone and a few scattered rounded crystalline rocks, that crop out at Twelvemile Church and at Flagg Spring Church. These conglomerates are similar to the "Split Rock conglomerate" and were, like the "Split Rock conglomerate," deposited in "Deep Stage" valleys by meltwater torrents during Illinoian time. Although bedrock altitudes of the divides along the bypass route have not been determined, the alluvial floors of the divides are remarkably uniform, ranging from about 600 feet to a little more than 620 feet, as determined from the topographic maps.

Although continued advance of the Illinoian ice sheet to the southwest was inhibited by the escarpment along the Licking River valley and by the highlands of the Cheviot prong, the southwest movement far to the north continued, for there, relief of the deeply entrenched "Deep Stage" valley that looped around the Cincinnati area was less. This major valley, acting as a drainageway to the southwest, carried melt water and debris from the ice front as the glacier approached the northern apex of the loop. At the same time, the Whitewater River probably was augmented by melt waters pouring into its basin far to the north, where its basin is now mantled by glacial deposits of Wisconsin age. The Whitewater drainage combined with the newly organized drainage funnelled through the North BendCleves passageway produced great torrents that coursed to the southwest, through the Glaciated Ohio River valley toward the Gulf of Mexico.

The ice sheet, progressing into the region of the northern apex of the great valley loop around the Cincinnati area, moved from the northeast without interference into the broad valley but was prevented from continuing to the southwest by the escarpment forming the west valley wall. In the north, away from the major drainage lines, the relief was lower, and the ice sheet could move forward unimpeded. In the region south of the Whitewater River valley, however, the escarpment was so effective as a barrier that the ice sheet did not penetrate the hill lands marginal to the valley or spread onto the Dearborn upland. The ice flow was thus deflected to the south along the broad valley (pl. 1). Forced by pressure from the advancing ice mass to the northeast, the ice within the valley moved southward into the more constricted steep-walled Ohio River valley. Gaining momentum, it was propelled forward as a narrow tongue down the sinuous Ohio River valley to the southwest, as far as the vicinity of Carrollton, Ky.

As ice filled the north part of the broad Great Miami River valley, drainage from tributaries such as the Whitewater River, from small creeks, and from the melting ice itself was forced to follow the fosse between the bedrock valley walls and the ice tongue within the 
valley. Where orientation of the valley walls was such that they were well exposed to the sun's rays and consequently heated, the lateral fosse must have been unusually well developed through melting of the ice within the valley. Stream and ice erosion along the valley walls produced oversteepening, for, in general, the ice tongue simulated a valley glacier. So easily eroded is the bedrock that no striated or polished surfaces appear to have remained, and the impression of a glaciated valley form is vague. Field evidence for the ice tongue rests almost wholly on the relatively fresh masses of till and glaciofluvial deposits within the valley that are unrelated to the deeply weathered glacial drift on the adjacent highlands.

Filling of the main valleys by the Illinoian ice tongue produced drastic rearrangements in the drainage patterns. Presumably, these major modifications resulted from the progressive forward movement of the ice tongue down the broad valley from the vicinity of Hamilton, Ohio (fig. 16). First, the vast quantities of melt water and debris from the advancing ice front were spread across the valley bottom. As the valley floor was progressively overwhelmed by the ice, drainage both from the ice surface and from the tributary streams draining the adjacent unglaciated highland areas was concentrated along the ice margin as though the ice tongue were a valley glacier. Except for the short marginal cutoff near Ross, about 5 miles southwest of Hamilton, Ohio (Shandon and Greenhills quads., Ohio), the first major drainage diversion appears to have occurred when the divide at New Baltimore was overtopped and a continuous marginal channel was produced, through which drainage flowed into the main valley in the vicinity of Fernald. Almost simultaneously, however, the channelway near Fernald may have been blocked by the advancing ice in the main valley so that the marginal stream was ponded and rose to overtop the divide at Mount Hope Church. When that divide was overtopped, a through-flowing channel was opened parallel to the broad ice-filled valley to the west. This channel was tributary to the North Bend-Cleves channel through which was flowing the drainage of the Ohio River basin above that point.

The ice tongue, advancing down the increasingly constricted valley from a point 4.5 miles above Valley Junction, soon blocked drainage from the North Bend-Cleves passageway south of Valley Junction (fig. 17). On reaching the North Bend-Cleves channelway, the terminus of the ice tongue escaped from the confining east valley wall and expanded into the channelway far enough to permanently seal with glacial drift the passageway through the bedrock divide. Drainage of the newly organized channelway now occupied by the Great Miami River between Ross and Cleves does not appear to have been ponded at this time, for no lacustrine deposits have been noted that could be assigned an Illinoian age. This leads to the belief that the waters must have escaped by a passageway to the southwest along the ice margin, perhaps aiding in the production of the relatively smooth east valley wall along the present lower valley of the Great Miami River from Cleves southwest to Fort Hill (Hooven quad., OhioIndiana-Kentucky, and Lawrenceburg quad., KentuckyIndiana-Ohio).

As soon as the North Bend-Cleves passageway was permanently blocked, the waters upstream were ponded and rose until they overtopped the col near Mile 488 of the present Ohio River. Thus, the channel of the Ohio between the mouths of the present Little and Great Miami Rivers (fig. 17) became organized across three divides. This channel, formed immediately in front of the ice-covered area of Illinoian time, supplanted the northern loop around the Cincinnati area that had formed during Nebraskan time.

After the opening of the through-flowing channel now followed by the Ohio River from the mouth of the Little Miami to the mouth of the Great Miami (fig. 17), the flow to the north that had been halted in the ice-blocked Licking River valley was henceforth reversed to become tributary to the through-flowing westward drainage of the Ohio. In this tributary valley, now occupied by Mill Creek, lacustrine deposits of Illinoian age are mantled by Illinoian till (Fenneman, 1916; Durrell, 1961). Presumably the surface of these deposits within the valley provided a southerly slope from the ice front on which the proglacial drainage to the south was initiated before the waning of the ice.

Waning of the ice from the Norwood trough, a broad and locally steep walled valley between the Little Miami and Mill Creek valleys, left the trough abandoned by major streams. Like the Mill Creek valley, this deeply alluviated trough is filled with lacustrine deposits and glacial till of Illinoian age, but unlike the Mill Creek and Little Miami valleys, it is drained only by small creeks tributary to the Little Miami River on the east and Mill Creek on the west (Fenneman, 1916). The lack of major streams in the Norwood trough has inhibited removal by erosion of its glacial fill, so its depositional valley bottom today is nearly undissected and high above the general level of the Mill Creek and Little Miami valleys.

If the valley of the present Ohio River between the mouth of the Great Miami and the vicinity of Carrollton, $\mathrm{Ky}$., was at one time ice filled, an explanation is required for the disposition of the drainage of the Ohio River basin above the mouth of the Great Miami. The drainage was torrential, as it consisted of the flow from the unglaciated basin of the river and from the proglacial melt waters issuing from the ice sheet along its terminal 
margin from western Pennsylvania to southeast Indiana. Because no evidence has been found to suggest that the drainage circumvented the present Ohio valley below the mouth of the Great Miami by a channel such as that of Eagle Creek, one is led to the not-toosatisfactory conclusion that the "Deep Stage" valley of the Ohio River was occupied simultaneously both by the long, narrow, sinuous ice tongue and by the drainage torrents.

At the time of the maximum advance of the Clermont lobe of the Illinoian ice sheet in southwest Ohio, the preIllinoian drainage had been so modified that the drainage of the Great Miami valley was forced along the ice margin for about 4 miles along the lower ice-filled river valley. Also, the closure of the North Bend-Cleves passageway by the plug of Illinoian till, had permanently forced drainage from the upper Ohio valley into its present channel above the mouth of the Great Miami, where the Ohio drainage joined the ice-marginal stream of the Great Miami valley. If the drainage torrents and the narrow ice tongue occupied the Great Miami valley simultaneously, then, as the ice tongue pushed into and down the deep Ohio valley, already in use as the major drainageway, the ice must have pushed aside the torrential waters into ice-marginal channels. This assumes that the volume of ice was sufficiently great and the rate of replenishment fast enough that the ice was not melted by the drainage torrent until reaching the Carrollton area. At that point, alimentation of the ice tongue was overbalanced by melting, so the tongue could no longer continue down the valley.

No evidence, such as lateral channel cutting along the bedrock valley walls, has been found to indicate that this valley ice tongue lasted a long time. The ice tongue may have been the result of a short local catastrophic surge.

A single short-lived well-known channel in the vicinity of Petersburg, Ky., between Miles 494 and 499, is immediately downstream from the confluence of the Great Miami and Ohio Rivers (pl. 2C). Drainage torrents poured through it after overtopping a low divide between the headwaters of two opposing creeks, one draining to the north, the other to the south. In origin, this channel is similar to channels now occupied by the Great Miami and Ohio Rivers in the immediate vicinity; torrents blocked in their normal flow down the valley when it became ice filled were ponded in the valley of the north-flowing creek until a col between it and the south-flowing creek was overtopped and a continuous channel was provided. Both volume and velocity of the torrential flow permitted large predominantly angular blocks of locally derived bedrock and minor amounts of rounded crystalline glacial boulders to be transported through the channel. At the mouth of the channel, where velocity of flow was reduced, the transported debris was dropped in a great jumbled kamelike mass adjacent to the mouth of Woolper Creek to form the "Split Rock conglomerate." Immediately downstream, the finer outwash formed an extensive kamelike apron between the valley wall and the ice tongue within the valley. Remnants of this outwash appear today about 150 feet above the Ohio River pool stage as an unusually high terrace remnant that has the distinction of being the only terrace of Illinoian age identified within the Glaciated Ohio River valley. The terrace is locally blanketed by sand dunes of Wisconsin age.

During Illinoian time, no stream carrying melt water and fluvioglacial debris entered the Glaciated Ohio River valley downstream from the mouth of the Great Miami River. All other drainage from the Illinoian ice sheet in southeast Indiana was funnelled into the basin of the Wabash River (fig. 1). Glacial drainage into the headwaters of the Blue River (a tributary of the Ohio at Mile 663 along the Constricted Ohio River valley) is believed to have occurred during Nebraskan time rather than during Illinoian time, as suggested by Thornbury (1937), because the Illinoian ice sheet did not ascend to the upland surface west of the Scottsburg lowland to reach the headwaters of Blue River in that area.

When the Illinoian glacier waned, the river valley above Louisville, $\mathrm{Ky}$., was freed from glacier ice for the last time, and its present course had been established. If a valley train of Illinoian age formed along this part of the Ohio River valley, no evidence of it remains today except the deposits of loess that are genetically related to it (pl. 1). Presumably, outwash of Illinoian age has been in large part, perhaps wholly, removed by erosion. Whatever remnants may remain have apparently been covered and obscured by outwash deposits of Wisconsin age. Gradually the glacial regimen of Illinoian time was supplanted by the nonglacial regimen of Sangamon time, and a new set of controls began to affect the river, now established in a course that has remained until the present.

\section{SANGAMON INTERGLACIAL TIME}

Like the Aftonian and Yarmouth interglacial times, the Sangamon interglacial time had time-transgressive boundaries and was characterized by a distinct amelioration of the climate from a rigorous glacial climate to a relatively mild nonglacial climate. The Illinoian ice sheet either completely disappeared from the North American continent or was so withdrawn to the north that it had no effect on the Glaciated Ohio River valley region. When the ice withdrew from the basin of the Ohio River, a time of weathering and erosion began. The drainage pattern of the Glaciated Ohio River and its major tributaries had assumed essentially its present form. Drainage, when freed from the meltwater torrents and accompanying fluvioglacial debris, 
flowed unimpeded along its present course to the southwest, its regimen gradually shifting from that of an aggrading glacial stream to a degrading nonglacial stream (Ray, 1965a, p. 25-29).

Although fluvioglacial debris is presumed to have formed an outwash plain within the narrow valley of the Ohio below the tip of the sinuous ice tongue of Illinoian age, there is little evidence to support its existence, for no erosional remnants of such an outwash train are present. All deposits noted by Leverett (1929) as of possible Illinoian age have turned out to be of Wisconsin age. Presumably, whatever outwash may have been deposited has been removed by subsequent erosion or has been buried and concealed beneath outwash of Wisconsin age. That such an outwash plain did exist, however, is indicated by the thin, deeply weathered deposits of loess of Illinoian age, which first appear along the Ohio River valley near Goshen (Owen quad., Kentucky-Indiana), above Louisville, Ky. Downstream, deposits of loess of Illinoian age are important members of the loess stratigraphy (Ray, 1957, 1963a, 1965a). Near Goshen, the loess had presumably been deflated from an Illinoian valley-train source area to the northwest, where the Ohio crosses the Scottsburg lowland and the valley walls are so low that the dominantly northwest winds would have ready access to the valley-train surface, sweeping up the sediments and carrying them to the adjacent hill lands. During Sangamon time, this loess was deeply weathered to the red-brown hue so characteristic of Sangamon weathering elsewhere.

Above Carrollton, $\mathrm{Ky}$., in the region where the Ohio valley was occupied by the tongue of Illinoian ice, loess assignable to an Illinoian age is absent, presumably because there was no outwash train suitable for a source area for the deflation of loessial sediments. After the disappearance of the ice tongue, outwash may have accumulated in the river valley, but the valley was so deep and narrow that winds presumably could not easily deflate the outwash surface. The possibility was considered that a shallow lake might have briefly occupied the site of the ice tongue after it melted, but no supporting field evidence was found.

Where till of Illinoian age is exposed at the surface, it is more modified by weathering than are the younger deposits of Wisconsin age and less modified than are the older deposits of Kansan and Nebraskan age. Unlike the older deposits, those of Illinoian age still possess in places vestiges of the original surface configuration. Instead of being leached of primary carbonates to depths of more than 10 feet, deposits of Illinoian age are commonly leached only to depths of 6 to 8 feet. The depth of leaching depends largely on the topographic position of the deposit, which in turn influences the movement of ground water within the deposit. In flat terrain, depths of leaching tend to be less than in hilly terrain, where ground-water drainage is good. Furthermore, weathering in place during Sangamon time has produced disintegration of the crystalline rocks only to shallow depths and has permitted the development of only thin gumbolike silty-clay surficial deposits, whose thickness in low-lying areas may be somewhat increased by colluvial wash of weathering products from higher points on the till surface. Because of the longer time involved, thicker weathering deposits are more characteristic of the older and surficially flatter Kansan and Nebraskan tills. In flat areas, such silty-clay deposits inhibit downward percolation of ground water, so leaching at depth, already slight, tends to be further inhibited.

Where surficial deposits of Illinoian till are poorly drained, as on the relatively flat areas of Clermont County, Ohio, a thin gray to white deoxidized surficial layer of silty clay has formed by weathering processes. This layer is similar in appearance to the "fine whitish clay soil termed loess" (Malott, 1922, p. 158) that is present on the poorly drained tills of southeast Indiana, here interpreted to be of Kansan and Nebraskan age (pl. 1). Along the Mississippi River in western Kentucky and Tennessee, similar light ashy-gray surficial layers have formed by weathering of poorly drained thin deposits of loess of Wisconsin age (Ray, 1967). These Russell (1944) suggested to be of lacustrine backswamp origin. In the region of the Glaciated Ohio River valley, several differing parent materials have been suggested for these distinctive grayish to whitish soils. Leverett (1892) believed that the parent materials were fluviolacustrine; Fenneman (1916) and Malott (1922), that they were loessial; Westgate (1930) and Hendrickson and others (1930), that they were poorly drained tills. It is proposed here that all these whitish soils formed from different parent materials have a common bond in their poor drainage, which has so dominated the weathering processes that a similar-appearing end product has resulted. Furthermore, as long as such poor drainage conditions exist, the whitish-soil end product of weathering will remain essentially stable. Thus, such soils cannot be used as criteria to determine age of the parent materials, for with sufficient time and under similar conditions, they can be present on tills of all ages.

Except for weathering and minor erosion of the surficial deposits, the main activity during Sangamon interglacial time appears to have been removal of glaciofluvial deposits from the major stream valleys. Whether or not this removal of debris from the valleys swept them clean so that interglacial stream erosion could once again attack bedrock is not known. It is suspected, however, that in places the river may have 
cut into its bedrock valley floor (Ray, 1965a). Drainage patterns were stabilized, and superficial landscape changes through weathering and erosion were minimal. Changes during Sangamon interglacial time appear to have been less than during either Yarmouth or Aftonian interglacial times.

\section{WISCONSIN GLACIATION}

The last of the four great Quaternary glaciations in the Ohio River basin, the Wisconsin, was much less extensive areally than the earlier glaciations. Moving from the northeast to the southwest, the glacier at the time of its maximum advancement did not reach the Ohio River valley proper, although a small frontal ice tongue protruded into Mill Creek valley in the Cincinnati area to a point only a few miles from the river (pl. 1). Despite its lesser areal extent, the Wisconsin ice sheet had a profound effect on the valley as seen today, because the valley was a sluiceway for outpourings of melt water and fluvioglacial outwash.

Upstream from the Glaciated Ohio River valley, melt water and outwash poured into the river's main stem through many tributaries, some as far east as western New York State. In the glaciated sector, melt water and outwash entered the main stem only through a few tributaries-the Little Miami River, Mill Creek, and the Great Miami River. No tributaries between the Great Miami and the mouth of the Wabash (fig. 1), about 200 airline miles to the southwest, carried melt water or debris from the Wisconsin ice front to the Ohio River valley. Melt water and debris issuing from the ice front in Indiana were funneled only into the basins of the Great Miami or the Wabash Rivers.

The Wisconsin ice sheet in southwest Ohio and southeast Indiana consisted of two small lobes, the Miami lobe (Goldthwait and others, 1961) in southwest Ohio and southeast Indiana, and the lobe in southcentral Indiana that is here termed the White River lobe (pl. 1). Whether these two lobes were contemporaneous is not known, although it is suspected that they were at least formed penecontemporaneously at the time of the maximum local ice expansion. Everywhere along its outer boundary, the Wisconsin drift is readily distinguished from older drift by its generally fresh and unweathered appearance and by the well-preserved constructional terrain features. The Wisconsin deposits are generally leached only to depths of 3 to 5 feet, and constructional glacial terrain features, such as moraines, have been relatively little modified by postglacial weathering and erosion. Yet, along the margin and for several miles back from the position of the ice front, the main characteristics of the bedrock topography have not been wholly erased, and, despite the mantle of glacial drift, the Dearborn upland, Muscatatuck regional slope, and Scottsburg lowland retain their characteristic features.
Farther north, however, the increasing thickness of the glacial drift is sufficient to obliterate the features characteristic of the bedrock terrain (Malott, 1922).

No attempt is made in this report to review the many fluctuations of the Wisconsin ice sheet and the attendant stratigraphy of deposits, for they have little direct bearing on the problems considered here. Each major waxing and waning of the ice sheet, however, profoundly affected the regimen of the Ohio River and the resultant deposits within the valley. Periods of river aggradation alternated with periods of degradation; valley trains were formed during times of aggradation and partly removed during times of degradation, resulting in a series of paired river terraces. Ray (1965a) discussed the mechanics of aggradation when the river was amply supplied with melt water and fluvioglacial debris and of degradation when streamflow and outwash debris were reduced in volume. Presumably the greatest volume of melt water and outwash was channeled into the rivervalley sluiceway immediately after the beginning of a waning phase of glaciation and for an indefinite but presumably short time thereafter. During a waxing phase of glaciation, the volume of melt water and outwash presumably would not have been as great. Therefore, the time of river aggradation and formation of valley trains would be markedly shorter than the time of river degradation, which included both the time of maximum ice recession and the time of ensuing readvancement.

\section{VALLEY TRAINS AND TERRACES RESULTING FROM THE WISCONSIN GLACIATION}

Fluctuations of the ice sheet of Wisconsin age were the basic causal factor in the formation of the Wisconsin terraces along the Glaciated Ohio River valley. Presumably, successive terrace levels represent outwash of distinct, but successively smaller, readvances of the fluctuating ice sheet. Two successive periods of valleytrain development, separated by a period of active stream degradation, have resulted in two terraces along the main stem of the Ohio and along the lower courses of its tributaries (Ray, 1965a).

\section{THE TERRACE OF TAZEWELL AGE}

The highest terrace level along the Glaciated Ohio River valley, except for the few kame-terrace remnants of Illinoian age near the mouth of Woolper Creek, consists of erosional remnants of a valley train that are readily identifiable and have been traced in the field from the vicinity of Cincinnati almost to the mouth of the present Ohio River valley. Fenneman (1916) noted that the outwash train represented by this terrace is correlative with the maximum advance of the Wisconsin glacier in the Cincinnati region (pl. 1). Furthermore, it is 
coincident with the terrace of Tazewell age in the Owensboro, Ky., area (Ray, 1965a), which has, in turn, been correlated with the terrace representing the maximum alluviation of Wisconsin age in the Wabash valley (Fidlar, 1948). Correlation of this highest terrace level with the maximum advance of the glacial ice has been substantiated by carbon-14 dates of $18,520 \pm 500$ and $19,940 \pm 300$ years B.P. for wood from related terrace deposits (Rubin and Alexander, 1960, samples W-520 and $\mathrm{W}-645$ ).

That the widespread ice advance of Tazewell time was not the first advance of Wisconsin age is now generally accepted, and many believe that the time of the earliest advance is much earlier than was formerly thought. ${ }^{5}$ The pre-Tazewell history of the Wisconsin Glaciation has been, however, the subject of much discussion and divergent interpretation and has not yet been firmly established by a uniform chronology throughout the central United States. (For differing chronologies, see Karlstrom, 1961, 1968, and Wright and Frey, 1965.)

Evidence for the existence of a valley train along the main stem of the Ohio River of a Wisconsin age older than the Tazewell, and presumably correlative with the pre-Tazewell advance, rests on the presence of the Farmdale Loess (Ray, 1960). Along the valley below Louisville, a distinctive loess unit, the Farmdale, lies stratigraphically above the Sangamon profiles of weathering developed on the loess of Illinoian age and below the Peorian Loess of Tazewell age (Ray, 1957, $1960,1963 a, 1965 a)$. A valley train of early Wisconsin age, formed before Tazewell time, must have been the source area for the Farmdale Loess. Because no terrace remnants representing such a pre-Tazewell valley train have been observed, the valley-train surface must be

${ }^{5}$ The writer, on the basis of his observations of the profiles of weathering of loess in France (Normandy) and along the Ohio River valley, suggests the possibility that Sangamon interglacial time is correlative with the Mindel/Riss interglacial time of Europe and that the early, pre-Tazewell Wisconsin Glaciation in the United States may be correlative with the Riss Glaciation of Europe, a possibility suggested also by Richmond (1969). concealed below the Tazewell outwash or must have been completely removed by pre-Tazewell erosion. Such erosion seems less likely than the more realistic belief, even without field verification, that whatever remnants of the Farmdale valley train may have been present, they are now concealed beneath the valley-train deposits of Tazewell age.

The history suggested is one of marked post-Illinoian erosion of outwash within the Ohio valley during the long Sangamon interglacial time, followed by deposition of a pre-Tazewell valley train as a result of the first advance of the Wisconsin ice sheet. Because the surface of this early, Farmdale valley train above Louisville was nestled deep within the narrow steep-walled valley, it was not as readily accessible to wind deflation as was the younger, Tazewell outwash at a somewhat higher altitude within the valley. This can explain why remnants of Farmdale Loess, which would necessarily be thin, easily eroded, and deeply weathered, have not been observed above the Louisville area, although thin weathered characteristic deposits of Peorian Loess are present adjacent to the valley where it is widest or oriented suitably for maximum deflation during Tazewell time. Possibly, the weathered Farmdale Loess cannot be distinguished from the overlying thin weathered Peorian Loess (Ray, 1965a, p. 45).

Terrace remnants composed of outwash of Tazewell age in the main valley of the Ohio were first studied by the writer in the Owensboro, Ky., area (Ray, 1965a). Their genesis and characteristics have proved to be similar throughout the Glaciated Ohio River valley. A reconstruction of the outwash-train surface, as determined by altitudes of the terrace remnants, indicates that the average slope is not constant but is an extended parabolic curve (fig. 18). Between Louisville and Cincinnati, the terrace remnants rise from an altitude of about 460 feet to one of about 540 feet in 135 river miles, an average gradient of about 7.1 inches per river mile, in

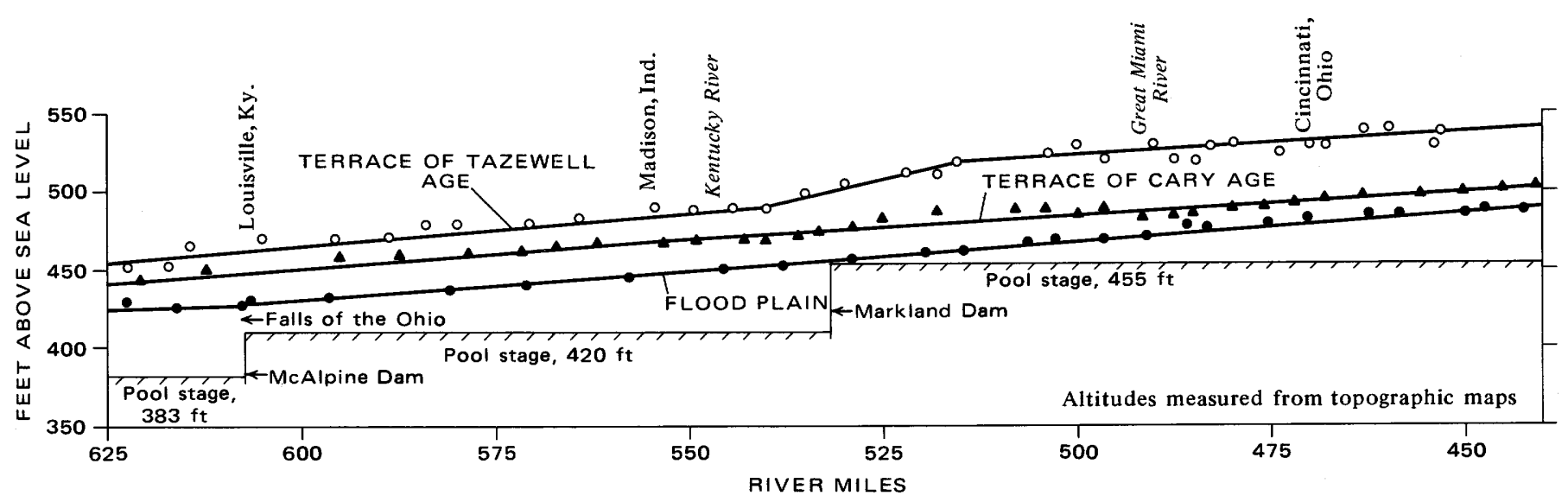

Figure 18.-Profiles of the two terraces of Wisconsin age and the flood plain of the Glaciated Ohio River valley. 
contrast to an average gradient of 5.7 inches per river mile from Louisville to Owensboro, about 140 river miles downstream. The gradient steepens in the main valley as the major sources of glaciofluvial sediments are approached. As pointed out by Leverett (1929), the surface of the Tazewell outwash rises rapidly upstream in the sluiceways to the source of the outwash debris adjacent to the ice front. Downstream from the confluence of the Great Miami River valley, which was the major source of the outwash dumped into the Ohio valley, the gradient is oversteepened by a deltalike mass of outwash that extends downstream as far as the vicinity of Florence, Ind.

The surface of the Tazewell valley train, now represented by the highest terrace remnants, is underlain by thick deposits of silt and silty dune sand on which zonal profiles of weathering are well developed. Because the terrace surface is above the level of the greatest known floods, it is valuable for industrial sites and has been utilized for extensive urban development.

The fluvioglacial components of the terrace remnants are, in general, poorly exposed. Because of the nature of the outwash deposition (for a discussion of the formation of the valley train, see Ray, 1965a), gravel rarely crops out on the surface, and terrace slopes are mantled by a silty or sandy slump derived from the surficial deposits. This finer alluvium overlies well to poorly stratified, crossbedded, lenticular, fine to coarse, angular to well-rounded sand and gravel, together with a few large boulders. Gravel consists largely of limestone, dolomite, and chert but has smaller percentages of various crystalline rock types. Commonly, the coarse angular sand and fine gravel are loosely packed without a matrix of finer material filling the voids between the particles. In only a few places has postdepositional cementation filled the voids with secondary carbonates, yet ground water derived from wells penetrating this terrace is always highly charged with dissolved salts.

The largest and most active gravel pits along the Glaciated Ohio River valley have been opened in the Tazewell terrace near Belleview, Ky., and at Mexico Bottom, Ind. (Rising Sun quad., Kentucky-Indiana), along DeWeese Creek in Kentucky (Madison East quad., Kentucky-Indiana), and near Utica, Ind., on a reduced remnant of the terrace (Jeffersonville quad., IndianaKentucky). Large gravel pits are also worked in the lower Great Miami valley and near the mouths of some of the larger tributaries to the Ohio, such as Laughery Creek near Aurora, Ind. (Aurora quad., IndianaKentucky). Small temporary gravel pits supply local needs and are present throughout the valley as ephemeral features commonly opened along the marginal slopes of the Tazewell terrace. Scattered bones and teeth of the mastodon and mammoth are commonly present in the gravel deposits and are retrieved primarily as curiosities.

Remnants of the Tazewell terrace are commonly mantled by low scattered irregular sand dunes normally only a few feet high. The dunes are especially well developed on the terrace surface between the confluence of the Ohio with the Great Miami River and Madison, Ind., and can be readily identified on the topographic maps (figs. 12-15). The sand is, in general, so fine grained and silty that it is of little importance commercially and commonly is removed as overburden from gravel pits. On the broad terrace flats of Tazewell age on which a large part of the City of Louisville, $\mathrm{Ky}$., is built, there are linear dunes similar to but not as well developed as those of the Owensboro area (Ray, 1965a). Most have been obliterated or obscured by urban development, but a few appear on the Louisville West quadrangle (Kentucky-Indiana) south of the University of Louisville between Crittenden Drive and the railroad yards. This dune ridge extends to the southwest into Southern Heights and can be observed near Southern Junior High School. South of Algonquin Parkway, between Cane Run and -Miller Roads, is a similar dune ridge. Leverett (1929) suggested that the dune ridge in Southern Heights, like the largest of the dune ridges at Owensboro, Ky., was a natural levee deposited between the strong currents of the Ohio River on the one hand and the backwaters that submerged to a shallow depth the area behind the levee on the other. As at Owensboro (Ray, 1965a), there is no evidence to support Leverett's suggestion.

At all localities where dune sands were examined, the exposures were shallow, and the sands were leached of their primary carbonates. The dunes are composed of surficial weathered compact yellow to brown silty sand in which original stratification has been destroyed, for, like all dunes associated with the terrace surface of Tazewell age in the Ohio River valley, a zonal profile of weathering has formed. Primary carbonates in the thickest deposits of sand and silty sand are generally leached to depths of 10 feet or more. No fauna has been recovered from the dunes, presumably because whatever shells may have been present were removed during leaching of the deposits.

When the ice sheet of Tazewell age had retreated from its position of maximum advancement, river aggradation was supplanted by degradation, and paired terraces were formed on the outwash plain in the main Ohio valley and on the lacustrine sediments in the tributary valleys. The most conspicuous terrace remnants date from this time and are generally about 15 feet higher than the lower and younger terrace of Wisconsin age. 
LACUSTRINE DEPOSITS AND TERRACE REMNANTS OF TAZEWELL AGE IN VALLEYS TRIBUTARY TO THE SLUICEWAYS OF WISCONSIN AGE

In those valleys tributary to the Ohio, Great Miami, and Little Miami River valleys that were not sluiceways for glaciofluvial outwash from the Tazewell ice front, horizontal terrace remnants of lacustrine sediments are present at altitudes generally correlative with the surface of the valley train of Tazewell age at the confluence of each tributary with its related sluiceway. First recognized and explained as an important Quaternary landform by Shaw $(1911,1915)$, these terraces and their genesis are well known through the studies of Theis (1922), Thornbury (1937, 1950), and Ray (1965a). Ray reviewed their genesis and characteristics along the Ohio valley in the vicinity of Owensboro, Ky., where they are similar in all respects to those along the Glaciated Ohio River valley.

During deposition of the valley train of Tazewell age in the Glaciated Ohio River valley and in the Great and Little Miami Rivers and Mill Creek, those tributaries that were not sluiceways for fluvioglacial outwash were blocked and ponded at their mouths by the rapidly accumulating valley trains in the sluiceways. As the valley-train outwash grew thicker and its surface became higher, the depth of ponding in the tributaries increased until the valley train reached its maximum level of alluviation. At that time, backwaters in the ponded tributaries formed widespread shallow lakes that were prominent features of the landscape, in places extending for many miles back from the main valley in well-defined dendritic patterns.

Along the Glaciated Ohio River valley, especially between the mouth of the Great Miami and Madison, Ind., prominent terraces are ubiquitous features in the tributary valleys and are especially well developed in valleys of the larger streams, such as Gunpowder Creek (fig. 19) and the Little Kentucky River (fig. 20).

In the valleys of the largest tributaries from the south, the Licking and Kentucky Rivers, these terraces can be followed upstream for many miles at an almost constant altitude, as well as into and up the lower courses of the tributary creeks. For example, terrace remnants at an altitude slightly above 480 feet can be followed for many miles up the Kentucky River and up its tributaries, such as Eagle Creek (Carrollton quad., Kentucky-Indiana, and Worthville quad., Kentucky).

Similar ponding of tributaries must have resulted from valley trains of earlier glaciations. All vestiges, however, of such early ponding have apparently been removed by subsequent erosion or have been covered and obliterated by Wisconsin sediments, for no lacustrine sediments older than Tazewell have been observed in tributary valleys along the Glaciated Ohio River valley.
Areal extent of the lakes in the ponded valleys can be recognized today by the accumulated lacustrine sediments now preserved under the terrace remnants. These consist largely of blue-gray clayey silt and fine sand. Presumably, in the lower courses of the valleys the sediments are largely fluvioglacial fines washed into the ponded valleys from the glacial waters coursing through the sluiceways. Near the mouths of the tributary valleys, sand and pebbles are in places scattered in the lacustrine sediments, but in general they are not present far upstream from the valley mouth, where the finer sediments may be in large part diluted by the normal alluvial load deposited by the stream.

The lacustrine deposits are commonly weathered to a yellow or brownish gray to depths of 5 feet or more. Primary carbonates, leached from the upper 3 to 5 feet, have been carried downward and redeposited as irregular secondary nodules below the base of the leached zone. Such nodules are characteristic and diagnostic of these deposits throughout the Ohio valley region. In places they are so concentrated as to almost completely mantle roadside outcrops below the leached zone. Ray (1965a) termed them "popcorn nodules" because of their characteristic shapes which distinguish them from the less common, rounded nodules of primary carbonate present in the unleached zone at depth.

Whatever structure was present in the upper part of the terrace deposits has been destroyed by weathering. At depth, however, the deposits may be thinly to coarsely bedded or laminated and may have varvelike rhythms of clay layers separated by fine silt layers or partings. Such varvelike bedding apparently results from both diurnal and seasonal fluctuations in the amount of melt water and debris poured from the glacier into the sluiceways; these fluctuations regulated the size and amount of sediments accumulated in the ponded valleys. Thickness of the lacustrine deposits is generally not possible to determine without drilling but may be as much as 70 feet at the mouths of some tributary valleys. The thickest section observed along the Glaciated Ohio River valley was about 40 feet in the valley of Long Run near Vevay, Ind. Generally the terrace remnants are slumped and so overgrown that there is little opportunity to examine thick sections to determine their characteristics and possible fossil content.

Few fossiliferous lacustrine deposits have been found, but a small fauna of fresh-water gastropods and pelecypods was recovered in the Owensboro region by Ray (1965a). This fauna indicates that the climate near Owensboro at the time of deposition was not appreciably different from that of today. Fossils collected from sandy lacustrine silts near Pleasure Ridge Park, Ky., are reported here. 


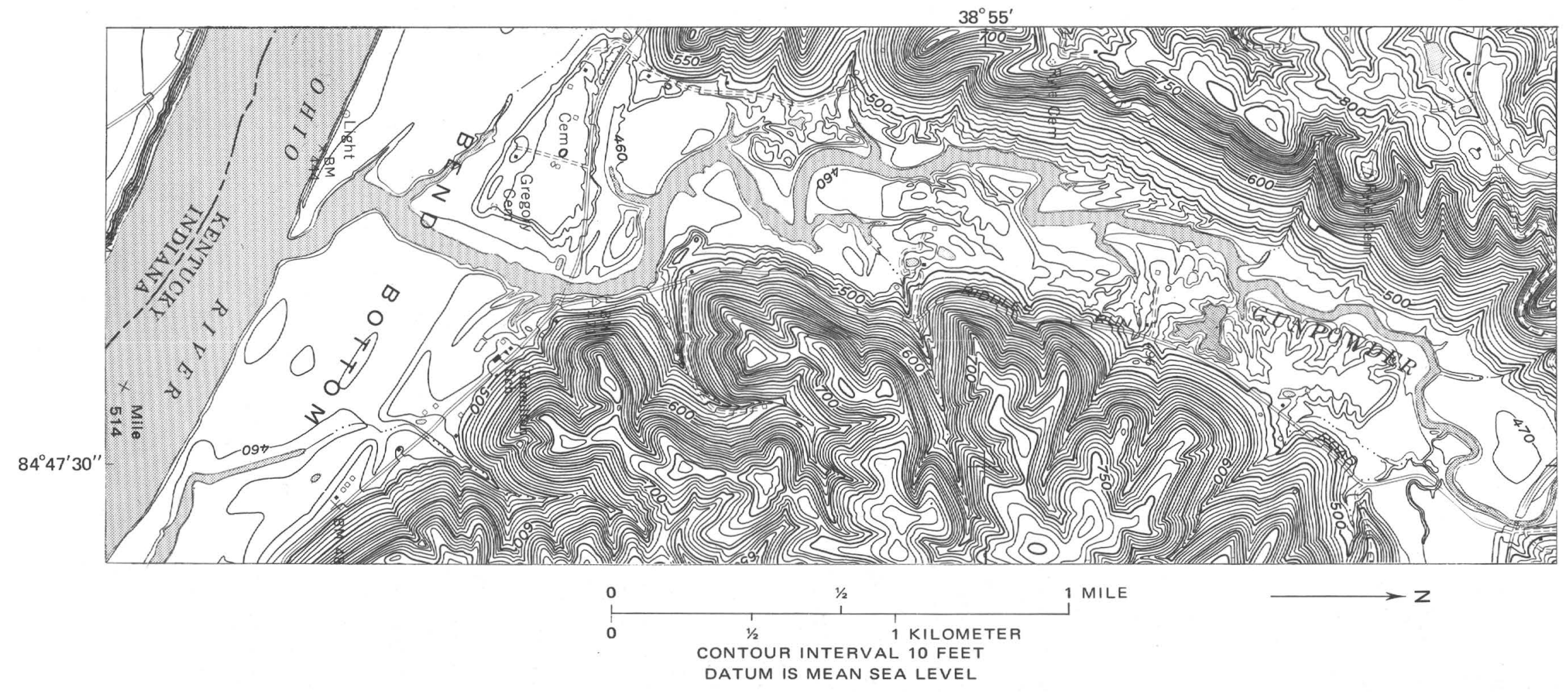

FiguRE 19.-Remnants of dissected terrace of Tazewell age in lower Gunpowder Creek valley. Original terrace surface between 490 and 500 feet in altitude. From U.S. Geological Survey Rising Sun, Ky.-Ind., 1961, 7/2-minute quadrangle. 
$38^{\circ} 40^{\prime}$

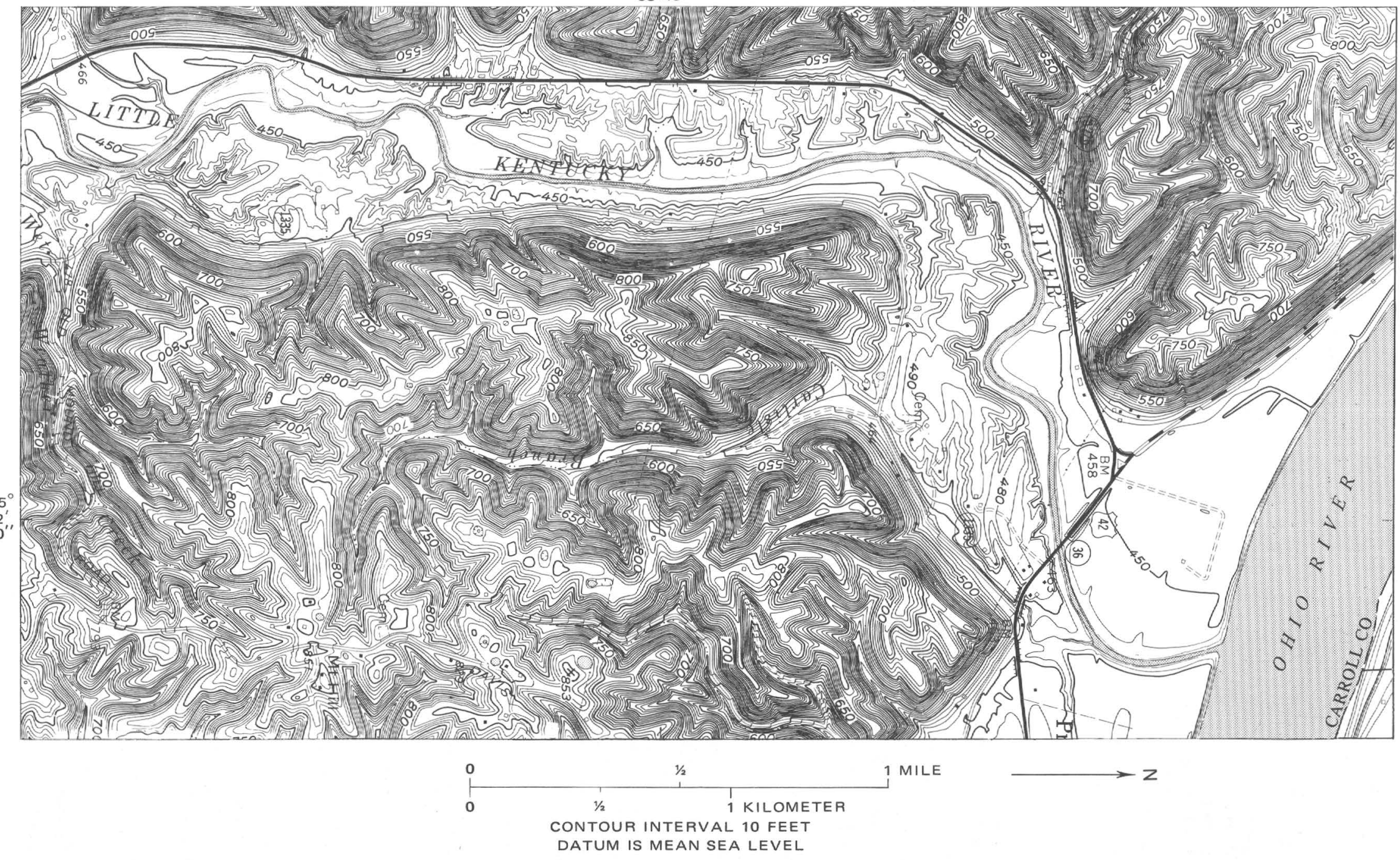

Figure 20.-Remnants of dissected terrace of Tazewell age in lower valley of Little Kentucky River. Original terrace surface between 490 and 500 feet in altitude. From U.S. Geological Survey Carrollton, Ky.-Ind., 1967, 71/2-minute quadrangle. 
Shells from artificial excavation along a dead-end road about 800 feet
south of St. Andrews Church Road and half a mile southwest of St.
Pauls School, Pleasure Ridge Park (Louisville West quad.,
Kentucky-Indiana)
[Site along tributary of Big Run Creek between a small isolated loess-covered bedrock hill and
the Ohio River valley wall. All fossils identified by J. P. E. Morrison, U.S. Natl. Museum]
Pulmonate gastropods:
Succinea ovalis (Say)
Succinea avard (Say)
Retinella electrina (Gould)
Stenotrema barbatum (Clapp)
Stenotrema leai (Binney)
Triodopsis multilineata (Say)
Haplotrema concavum (Say)
Fresh-water gastropod:
Fossaria modicella (Say)

This assemblage of gastropods indicates a marginal pond habitat rather than open waters. Inasmuch as Retinella electrina (Gould), Stenotrema leai (Binney), and Triodopsis multilineata (Say) are reported to be at the present southern boundary of their geographic range here (J. P. E. Morrison, U.S. Natl. Museum, written commun., 1957), a climate only slightly cooler than that of today may be indicated.

Fossils have not been reported from most lacustrine deposits along the Glaciated Ohio River valley, but Patton, Perry, and Wayne (1953, p. 22) noted a few shell fragments tentatively identified as the fresh-water gastropod A mnicola cf. emarginata (Kuister) from a zone 28 feet below the surface of the 40 -foot section of thinly bedded lacustrine deposits in the valley of Long Run, near Vevay, Ind. (SE1/4 NW1/4 SE1/4 sec. 16, T. 2 N., R. 3 W., Vevay South quad., Indiana-Kentucky).

Wood fragments are common in places in the lacustrine deposits. Some, identified as ash, were recovered from the fossil locality near Pleasure Ridge Park, $\mathrm{Ky}$. and have been dated by carbon-14 methods to be $18,520 \pm 500$ years B.P., or of Tazewell age (Rubin and Alexander, 1960, sample W520).

An attempt was made to find the locality at Lawrenceburg, Ind., reported by Orton in 1871 to Warder (1872) and interpreted by Leverett (1902) as a soil zone possibly at the top of drift of Illinoian age within the Ohio valley. The locality along the riverbank was only exposed at low water and is now permanently submerged through canalization of the river. No samples of the wood collected by Orton from this site can be found for analysis. Descriptions indicate that the beds mentioned by Orton occupy the same stratigraphic position as beds of Hubert Court in the Owensboro quadrangle (Ray, 1965a). The Hubert Court beds have been interpreted as belonging to the interval of ice retreat that followed the early, pre-Tazewell Wisconsin glacial ice advance.
THE POST-TAZEWELL (CARY) TERRACE

After an interval of river degradation in postTazewell time, another major period of ice advance was followed by a staggered retreat of the ice sheet referred to as of middle Wisconsin (Cary) age. This important fluctuation produced a valley train of fluvioglacial outwash that now forms a terrace below the level of the older, Tazewell terrace. The Cary terrace of the Glaciated Ohio River valley is identical with the low terrace described in the Owensboro area (Ray, 1965a). Unlike the older terrace, the younger lacks the mantle of surficial dune sand. Although exposures are absent that would reveal the character of the underlying materials, the Cary outwash is probably composed of sands and gravels similar to those of the Tazewell terrace; overall grain size is perhaps somewhat finer either because the material has been moved a greater distance from its source or because it is in part reworked from the older outwash deposits. The profile of weathering on the surficial silts is immature and can be easily separated from the more mature profile on the Tazewell surface.

The terrace surface of Cary age is about 15 feet below that of Tazewell age (fig. 18), from which it is commonly separated by a well-defined scarp. It is 10 to 15 feet above the river flood plain, but only rarely does a wellmarked scarp separate the two; in most places the transition is marked by a gentle slope (compare figs. 12-15). Because the Cary terrace is subject to occasional flooding, it is not as extensively utilized as a source of sand and gravel and is not as densely populated or occupied by industrial sites as is the higher, Tazewell terrace, which has not been flooded in historic time.

When first studying the terraces of the Glaciated Ohio River valley, the writer thought there was sufficient evidence to define two terrace levels between the Tazewell terrace and the flood plain (Ray, 1965a). Later, however, he became convinced that there is only a single paired terrace level younger than that of Tazewell age and that the relatively ill defined surfaces and slopes between the flood plain and the well-defined Cary terrace are reduced remnants of the Cary terrace that are related to river degradation during formation of the river flood plain. Similarly, in the Owensboro area, it is commonly difficult to distinguish precisely between the flood plain and the lowest terrace, which was assigned a Cary age.

Comparison of the Tazewell and Cary terrace levels readily shows that the gradient of the younger terrace is less than that of the older terrace along the Glaciated Ohio River valley, and that the younger terrace lacks any indication of a deltaic mass of outwash dumped into the Ohio valley below its confluence with the Great Miami valley, as is true of the Tazewell terrace (fig. 18). 
In general, the average slope of the lower terrace approximates 5.8 inches per river mile between the mouth of the Great Miami River and Louisville, Ky. This is much lower than the gradient of 7.1 inches per river mile for the Tazewell terrace but is greater than that of the present flood plain of the river, which is about 4.6 inches per river mile between Cincinnati and Louisville, a figure based on the altitude of the 2-year flood, prior to canalization of the river, divided by the distance in river miles.

The age of the lower terrace is based on the belief that the last major advance of the Wisconsin ice sheet to form an outwash plain in the drainage basin of the Glaciated Ohio River valley was of middle Wisconsin (Cary) age (Zumberge, 1960; Ray, 1965a). No later advances of the ice sheet poured glaciofluvial outwash into the Glaciated Ohio River valley. The many minor fluctuations of the ice sheet of Cary age during its general retreat were so far removed from the Ohio River valley that they exerted little influence.

When the ice sheet of Cary age had reached its maximum point of advancement, drainage and fluvioglacial outwash were channelled mainly into the Glaciated Ohio River valley through such tributaries as the Scioto River valley and smaller valleys upstream or through the principal channel along the Great Miami River valley. Because no fluvioglacial outwash entered the Ohio valley between the Great Miami and the Wabash, all outwash underlying the Cary terrace below the confluence of the Great Miami and Ohio valleys was largely introduced through the Great Miami valley, although a part may have been obtained through the reworking of the older, Tazewell deposits upstream.

Thickness of the outwash of Cary age cannot be estimated, for no differentiation seems possible between the Cary and the older, Tazewell outwash. Drilling records studied in the Owensboro area revealed no possibility of a separation of the outwash into distinct and datable units. The time interval between dissection of the Tazewell outwash and deposition of the Cary outwash is believed to have been so short that the Cary outwash was deposited on the eroded surface of Tazewell and perhaps earlier outwash within the bedrock river valley and not directly on the bedrock valley floor.

In general, the areal extent of the Cary outwash plain was so limited within the narrow bedrock valley of the Glaciated Ohio River, and the time of its availability as a source area for deflation of loessial sediments was so short, that no recognizable blanket of loess appears to have been deposited on the adjacent hill lands. Whatever deposition may have occurred, the sediments were necessarily so thin, so readily weathered, and so mixed with the underlying soils that they are indistinguishable as a separate depositional unit.

\section{POST-CARY ALLUVIAL HISTORY}

About 13,000 years ago, the ice sheet of Cary age began a pulsating retreat from its position of maximum advancement. At that time, degradation by the Ohio River presumably began. Although waning of the ice sheet was interrupted by a series of minor glacial readvances that produced small moraines (Flint and others, 1959), degradation by the Ohio River was presumably unimpeded. Because fluctuations of the distant waning ice sheet were minor, the resultant changes that would have affected the regimen of the main stem of the river were smoothed out to the point of disappearance along tributary glacial sluiceways before reaching the river. At an unknown time during recession of the Cary ice sheet, the ice front retreated from the Ohio River drainage basin above Louisville, $\mathrm{Ky}$., and the river was freed permanently of the direct influence of the Quaternary glaciers. All ensuing events are, therefore, either nonglacial or postglacial.

Although the drainage basin of the Ohio River above Louisville was ice free, the main stem of the river was indirectly affected by the last fluctuations of the lingering Wisconsin ice sheet, for the rate of stream degradation was governed by the influence of the ice sheet on climatic conditions. Presumably, as the ice sheet continued to wane, the climate became somewhat warmer and drier, and the average annual flow of the river somewhat less, so that conditions more closely resembled those of today. Climatic fluctuations were presumably so slight that the extremes of temperature and precipitation, though sustained for longer periods, were no greater than the extremes recorded today during unusually cold or wet periods.

\section{FLOOD PLAIN OF THE GLACIATED OHIO RIVER VALLEY}

The last recorded event in the history of the Ohio River is the formation of the present flood plain through degradation and lateral shifting of the river in late glacial and postglacial time. Formation of the flood plain along the Glaciated Ohio River sector has followed the same principles outlined for the formation of the flood plain in the Owensboro area (Ray, 1965a, p. 25-28, 50-54). The flood plain is an alluvial surface constructed largely by lateral accretion of channel deposits along the shifting river and to a minor extent by overbank deposition during flooding. Because of the narrow bedrock river valley, shifting of the river has been inhibited, so the flood plain is restricted in areal extent and is thus less important as a geomorphic feature of the landscape than one would expect along a river of such magnitude. This narrow flood plain is in marked contrast to the broad flood plain of the Alluviated Ohio River valley 
downstream. Except for temporary or semipermanent summer cabins, which in places line the river banks, the flood plain is almost devoid of habitations, for it is normally inundated on an average of every 2 years or less.

Formation of the flood plain, initiated by the process of river degradation during the waning and disappearance of the Cary ice sheet, was rapid at first, but the rate of degradation decreased as the flow of the river decreased, so that today the flood-plain surface has almost reached a point of stability (Johnson, 1936). River activity is now primarily confined to whatever lateral shifting of the channel is permitted by the constricting bedrock valley.

Late-glacial (Pleistocene) events in the formation of the flood plain cannot be distinguished from recent (Holocene) events. Because the flood plain has formed during Wisconsin glacial time as well as Holocene time, it has been assigned to the undivided Quaternary Period.

Because the Ohio River has been canalized by highlevel dams, it is now so artificially controlled that its normal pool stages above the dams consist, in the Glaciated Ohio River valley, of three steplike levels (fig. 18). Under natural conditions, the height of the flood plain was almost coincident with or only slightly above the altitudes of the 1- to 2-year floods (Leopold and Wolman, 1957). Furthermore, the normal flood-plain surface commonly terminated at the river in a high, steep to vertical bank above mean water level. Now, however, because the river does not fall below the regulated pool stage, the flood plain can be observed at a wide range of altitudes above the regulated river level. For example, the altitude of the 2-year flood, before construction of the Markland Dam (Mile 531.8), was 456 feet (table 1), almost coincident with the present normal pool stage of 455 feet for the river above the dam. Upstream, the difference between the altitude of the river at pool stage and the altitude of the 2-year flood increases to a maximum at Mile 436.3, immediately below the Meldahl Dam. There, the 2-year-flood altitude was 493.3 feet, or 37.3 feet above the pool stage of the waters impounded by the Markland Dam.

The normal stage of the pool impounded by the Markland Dam, which is almost midway along the Glaciated Ohio River valley, is 35 feet above the normal pool stage below the dam (fig. 18). This high stage created behind the dam has resulted in drowning of the lower courses of small creeks as well as major tributaries, such as the Great and Little Miami Rivers (figs. 21 and 22) and the Licking River. Small alluvial islands and sand and gravel bars have been in part or wholly submerged.

The effect of the dams on sedimentation in tributary valleys was not noticeable in 1968 , but silting of the
TABLE 1.-Two-year flood altitudes along the Ohio River before construction of high-level dams

[Locations and altitudes from U.S. Geol. Survey and from U.S. Army Corps of Engineers, Louisville District Office]

\begin{tabular}{llll}
\hline & & & $\begin{array}{c}\text { Flood } \\
\text { altitude }\end{array}$ \\
Location & & & \\
(ft above sea level)
\end{tabular}

flood-plain surfaces immediately above pool-stage flooding in tributary valleys presumably will be accelerated where the water levels have been raised. Alluvium transported from the upper valleys of the tributaries will be deposited in the ponded waters of the flooded lower valleys. Furthermore, canalization of the river may inhibit point bar formation, although never of major importance, and relief on the flood-plain surface may be reduced and in time erased through overbank deposition in swales and depressions. The limited areal extent of the flood plain indicates that shifting of the river has been minimal and will, in general, continue to be so, largely because the narrow bedrock valleys and the impounded waters inhibit the shifting of the river channels even during flood stages.

In places the flood-plain surface is well defined between the river bank and a low scarp about 10 to 12 feet or more high that separates it from the older and higher Cary terrace. Elsewhere, the flood plain is difficult or impossible to define exactly, for its surface and the surface of the Cary terrace merge in long gentle slopes. When the surfaces cannot be separated on the basis of altitude, other criteria are necessary. Where scouring by flood waters has reduced parts of the Cary terrace to or almost to the level of the flood plain, the 


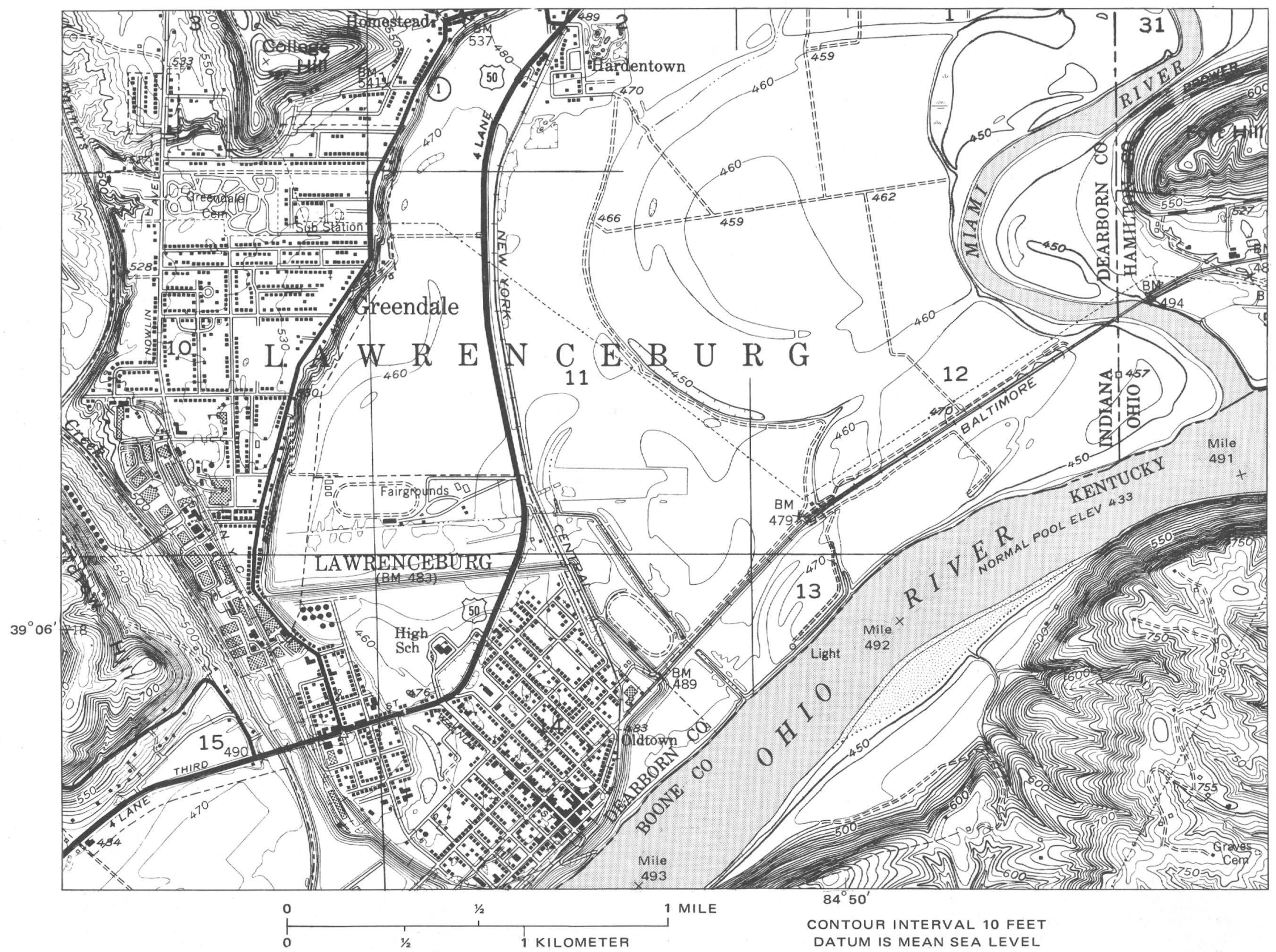

FiguRE 21.-Lower Great Miami and Ohio River valleys before installation of Markland Dam (Mile 531.5), about 39.5 miles downstream, which raised pool stage of river by 22 feet in this area. Abandoned meander on flood plain served as main channel of Great Miami River in 1847. Compare with figure $22 . \quad$ From U.S. Geological Survey Lawrenceburg, Ky.-Ind.-Ohio, 1951, 71/2-minute quadrangle. 


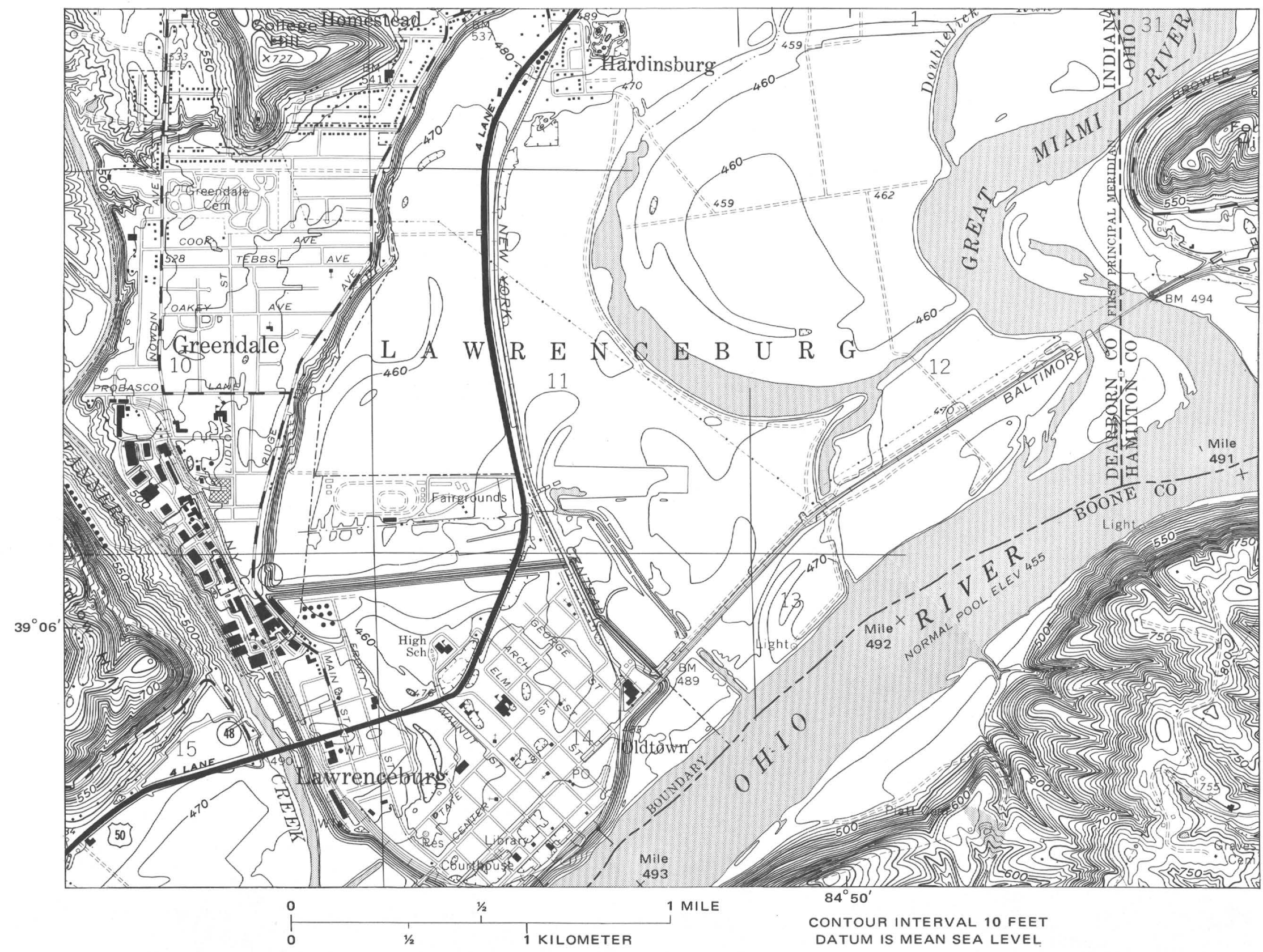

Figure 22.-Lower Great Miami and Ohio River valleys after completion of Markland Dam (Mile 531.5), about 39.5 miles downstream. Pool stage of streams raised 22 feet; lower course and abandoned meander of Great Miami River partly flooded. Compare with figure 21 
point of separation between the two surfaces may be indistinguishable. In the Owensboro area, where this is true, the conclusion was reached that the flood plain could be defined as that area across which the river channel had moved so that the underlying deposits have been shifted and reworked by the river during floodplain formation. Although this criterion is believed to hold for the Glaciated Ohio River valley, it is rarely possible to use, and one is commonly required to rely on the patterns of areal distribution of the two surfaces and on the alinement of surficial features as they relate to present river activity. Even this, however, may be inexact, for the lower parts of the reduced Cary terrace may be subject to scouring and to the same periodic flooding as the flood plain. In some places, however, the two surfaces can be distinguished on the basis of weathering of the surficial sandy silts, for silts of the Cary surface, where undisturbed and uneroded, have developed a profile of weathering which, though immature, is zonal, whereas the silty and sandy soils of the flood plain are azonal.

The flood plain is underlain by deposits as thick as 15 to 20 feet or more of yellowish sandy silt and silty sand containing scattered interbedded lenses of fine pea-sized gravel that is generally subrounded. Gravel is composed largely of chert but has minor amounts of crystalline rock. Below the surficial silty deposits is a thick layer of subrounded to rounded gravel intermixed with coarse to fine sand reworked from older deposits. The thickness of the coarse material at depth varies greatly and is generally not known. In some places the flood-plain deposits may extend to bedrock; elsewhere, they may overlie earlier outwash, from which they were in part derived and from which they cannot be distinguished. Because flood-plain deposits are largely reworked from older deposits, they are of similar composition but of somewhat smaller grade size.

Peaty humic beds interbedded in the alluvium have been reported to the writer in some areas, but none have been observed. Presumably, overbank deposition has left thin and insignificant deposits on the flood-plain surface during normal flooding. Scouring is presumably done during the higher floods when even the surface of the terrace of Cary age is inundated.

\section{THE FALLS OF THE OHIO}

The only break in the smooth parabolic gradient along the Glaciated Ohio River is at the Falls of the Ohio, between Clarkesville, Ind., and Louisville, $\mathrm{Ky}$. (New Albany quad., Indiana-Kentucky). There, where the river valley crosses the Scottsburg lowland and is at its widest, the river. unexpectedly tumbles over bedrock ledges in a series of rapids and small waterfalls. In a dis- tance of less than 2 miles, the river before canalization descended about 26 feet (Fenneman, 1938).

Because the "falls" were a serious obstruction to pioneer river traffic, especially during low-water stages, the first attempts at regulation were made early in the 19th century. Today, the McAlpine Dam dominates the "falls"; normal pool stage is 383 feet below the dam and 420 feet above the dam, a difference of 37 feet, or 11 feet greater than the reported natural river levels before canalization.

The resistant ledges of bedrock that obstructed the river and caused the falls are of Middle Devonian age and are, in part, the classic coral reef, well known to paleontologists (Hattin and others, 1961). Today, the highest altitude of exposed bedrock is slightly more than 400 feet, whereas nearby remnants of the highest alluvial terrace of outwash of Tazewell age are at an altitude of near 460 feet.

Before aggradation of the Ohio River valley, the river in the the vicinity of the Falls of the Ohio was entrenched in a bedrock channel. This channel, described by Guyton (1946) and MacCary (1955) as having a dendritic pattern of small tributaries, is now buried under about 130 feet of alluvial outwash. The alluvium in this channel, especially valuable as a reservoir for ground water, underlies part of the City of Louisville, Ky., south of the present river. Presumably, the channel is either the preglacial channel of a branch of Salt River or a later channel cut by the Ohio during the "Deep Stage" entrenchment in Yarmouth time. Although available information is insufficient to suggest either age, the later appears to be the most likely.

A less well defined buried channel in bedrock was reported by Siebenthal (1901) north of the present Ohio River in Indiana. Siebenthal assigned it a preglacial age. Here again, sufficient data are not available to demonstrate the age or the relationship of this channel to the channel under Louisville. Presumably, in Tazewell time, fluvioglacial outwash aggraded the bedrock river valley to an altitude at which the river flowed on its own alluvial deposits unhindered by the configuration of the underlying bedrock surface. Later, when degradation took place, the river did not follow its earlier bedrock channel but was superimposed on what appears to have been a small bedrock divide separating the main valley beneath Louisville from a small tributary valley to the north, a tributary possibly related to the channel noted by Siebenthal.

Because of the many manmade changes during urbanization of the area around the Falls of the Ohio, no attempt has been made to determine precisely when, other than in post-Tazewell time, the falls formed. Presumably they are so youthful that there was little incision of bedrock before canalization of the river. 


\section{BIG BONE LICK, KENTUCKY}

The classic vertebrate fossil locality at Big Bone Lick in northern Kentucky, about 20 miles southwest of Cincinnati, Ohio, has been known for more than 200 years. The geologic history of the bone-bearing alluvial deposits in Big Bone Creek valley is intimately related to that of the nearby Glaciated Ohio River valley (Schultz and others, 1963, 1967; Schultz and others, in Ray, 1965c). The site of the lick, a swampy meadow surrounding salt and sulfur springs in Big Bone Creek valley at its confluence with the valley of Gum Branch, is 2.75 airline miles northeast of the confluence of Big Bone Creek with the Ohio River (Rising Sun and Patriot quads., Kentucky-Indiana).

In the vicinity of Big Bone Lick, drifts of Nebraskan and Kansan age are present on the uplands; drift of Kansan age is also present in valleys cut below the upland level in post-Nebraskan time (Leighton and Ray, 1965; Ray, 1966). Drift of Illinoian age is present only within the bedrock Ohio River valley and on a low divide between Big Bone Creek valley and the valley of a small tributary to the Ohio about half a mile northwest of the fossil locality. The oldest of the alluvial terrace deposits at Big Bone Lick are referable to Wisconsin (Tazewell) time.

The terrace of Tazewell age in Big Bone Creek valley is represented by erosional remnants along the valley walls adjacent to the fossil locality. These remnants are composed of a compact slack-water lacustrine clayey silt deposited when the valley was ponded at its mouth by an outwash train of Tazewell age within the valley of the Ohio River. Today, erosional remnants of the Tazewell outwash plain are present as extensive terrace remnants along the Ohio River above the present level of flooding (Ray, 1965a, b, c). The lacustrine deposits, which are ubiquitous in the tributary valleys, and the prominent terrace associated with them represent typical slackwater alluviation in the formerly ponded tributary valleys along the main stem of the Ohio River valley (figs. 21 and 22).

Where lacustrine deposits have been exposed by artificial cuts to depths greater than the depth of leaching, they are calcareous, blue gray, and in most places filled with myriads of secondary calcareous concretions. Where these concretions have accumulated on the eroded surfaces, they are diagnostic of the Tazewell lacustrine deposits (Ray, 1965a). At Big Bone Lick, no vertebrate fossils have been recovered from the deposits of undoubted Tazewell age. The type skull of Boötherium bombifrons (Harlan) may be an exception, however, for it is said to have been collected at Big Bone Lick by William Clark during the 1807 expedition subsidized by President Thomas Jefferson. Plant remains recovered from the cranial cavity of this skull have a radiocarbon date of $17,000 \pm 600$ years B.P. (Ives and others, 1967), a date that can be construed as Tazewell. If this skull is truly from the Big Bone Lick site, it can, on the basis of the radiocarbon date, only have been recovered from the lacustrine sediments of Tazewell age.

In post-Tazewell time, intervals of erosion and alluviation produced two terraces below the Tazewell terrace and above the present flood plain of Big Bone Creek. These are now represented by erosional remnants at altitudes about 10 and 22 feet above the level of the creek. Unlike the terrace of Tazewell age, the younger terraces are subject to periodic flooding.

The alluvium of the highest post-Tazewell terrace consists of a surficial deposit of 12 feet or more of leached mottled gray silt with rusty iron staining. A zonal soil has been developed on the terrace surface. Below the surficial leached alluvium is a 1- to 3-foot layer of calcareous, deeply iron stained, gravelly, sandy silt from which wood and the bones of Mammut americanum, Mammuthus sp., Bison antiquus, Odocoileus sp., Equus cf. complicatus, and Paramylodon sp. have been recovered. A radiocarbon date of $10,600 \pm 250$ years B.P. (Levin and others, 1965, sample W1358) obtained from the wood indicates the age of the fauna but not the age of the terrace surface, which may be considerably younger.

Unconformably underlying the bone-bearing zone is an uneroded remnant of compact calcareous blue-gray lacustrine sediments believed to be of Tazewell age. There is no indication that these sediments are Tazewell sediments that have been reworked in post-Tazewell time.

On the lowest and youngest terrace surface are the salt springs and surrounding meadowland of the lick. Excavations in this terrace revealed 10 to 12 feet of calcareous sandy and clayey silt leached only to a depth of about 2 feet below the surface; no zonal profile of weathering has been formed. At depth, a layer of black humic bone-bearing gravelly silt in places overlies a barren blue-gray lacustrine valley fill, presumably of Tazewell age, that is similar to the lacustrine deposits under the higher terrace.

The bone-bearing horizons of the youngest terrace deposits are divisible into three zones. The first, 7.0 to 8.5 feet below the terrace surface, contains an association of modern bones and manufacts mixed with older bones, suggesting that this zone has been disturbed in historic time, possibly during earlier paleontological excavations. Bones of Canis sp., Bison bison, Bos taurus, Sus scrofa, Odocoileus virginianus, and Equus caballus were recovered from this zone.

The second zone, 8.5 to $11+$ feet deep, is a dark-gray to dark-brown humic silt and sand. Bones of Bison bison, 
Bison sp., Ovibos sp., Cervus cf. canadensis, and Odocoileus sp., and of proboscideans, Bison cf. antiquus, and Equus cf. complicatus, are present in the basal part of this zone. Because no bones were articulated and no bones of modern animals were intermixed, this zone appears to have been reworked by stream action from the underlying deposits that compose the third and oldest zone.

The third zone, of variable thickness, is present from depths of about 11 to more than 15 feet. It is a blue-gray silt that may be of Tazewell age, but more likely it is composed of Tazewell sediments reworked by stream action in post-Tazewell time. From this zone, bones of Mylodon sp., Mammut americanum, Bison antiquus, Cervalces scotti, Rangifer sp., and Equus cf. complicatus have been recovered. The underlying dark, blue-gray clayey silt, almost inseparable from the lowest bonebearing zone, has been excavated to a depth of 29 feet and may be either the original slack-water sediments of Tazewell age within the Big Bone Creek valley, or, like the overlying bone-bearing zone, the sediments of Tazewell age that have been reworked by stream action in post-Tazewell time. Augering in the Big Bone Lick alluvial flats indicates that the maximum depth to bedrock is 32 feet. No organic materials have been recovered from the basal deposits that could provide a radiocarbon date to indicate whether the blue-gray clayey silt between the bone-bearing zone and the bedrock of the valley floor is of Tazewell or postTazewell age.

Of the three terrace levels above the flood plain of the creek at Big Bone Lick, the highest is correlative with the Tazewell outwash plain in the Glaciated Ohio River valley and appears to be devoid of a vertebrate fauna. Only deposits of the two younger and lower terraces of post-Tazewell age contain productive bone-bearing zones. An undisturbed bone-bearing zone under the higher post-Tazewell terraces is dated between 10,000 and 11,000 years B.P. The bone-bearing deposits associated with the younger and lower terrace are believed to be in part reworked by stream action from the older deposits during the formation of the terrace and in part disturbed by excavations in this terrace in historic time, as attested by the presence of the bones of domesticated animals, crockery shards, articles of clothing, and other manufacts that are mixed with the bones of ancient or extinct animals. The so-called Big Bone Lick fauna may largely date from a time about 10,000 years B.P.

\section{REFERENCES CITED}

Bownocker, J. A., 1947, Geologic map of Ohio compiled by J. A. Bownocker; reprinted 1947 with revision of glacial boundary by George Willard White, and with changes in base map: Columbus,
Ohio, Ohio Geol. Survey, Scale 1:500,000.

Brand, L. S., 1934, Some notes on the Pleistocene history of the Cincinnati region: Ohio Jour. Sci., v. 34, no. 2 , p. 67-85.

Bushnell, T. M., [1958?], A story of Hoosier soils and rambles in pedological fields: West Lafayette, Ind., Peda-Products Publishers, $101 \mathrm{p}$.

Butts, Charles, 1904, Description of the Kittanning quadrangle [Pennsylvania]: U.S. Geol. Survey Geol. Atlas, Folio 115, 15 p.

Campbell, M. R., 1898, Description of the Richmond quadrangle [Kentucky]: U.S. Geol. Survey Geol. Atlas, Folio 46, 4 p.

Chamberlin, T. C., and Leverett, Frank, 1894a, Certain features of the past drainage systems of the upper Ohio basin [abs. with discussion]: Am. Geologist, v. 13, p. 217-219.

$-1894 \mathrm{~b}$, Further studies of the drainage features of the upper Ohio basin: Am. Jour. Sci., ser. 3, v. 47, p. 247-283, 483.

Coffey, G. N., 1958, Major glacial drainage changes in Ohio: Ohio Jour. Sci., v. 58 , no. 1 , p. $43-49$.

Collett, John, 1882, Eleventh annual report, 1881: Indianapolis, Ind., Indiana Dept. Geology and Nat. History, $414 \mathrm{p}$.

Cox, E. T., 1879, Eighth, ninth, and tenth annual reports of the geological survey of Indiana made during the years 1876-18771878: Indianapolis, Ind., Geol. Survey Indiana, $542 \mathrm{p}$.

Cressman, E. R., 1964, Geology of the Tyrone quadrangle, Kentucky: U. S. Geol. Survey Geol. Quad. Map GQ-303, scale 1: 24,000.

Culbertson, Glenn, 1908, Some peculiarities in the valley erosion of Big Creek and tributaries: Indiana Acad. Sci. Proc., 1907, p. 101-103. 1916, The geology and natural resources of Jefferson County [Indiana]: Indiana Dept. Geology and Nat. Resources Ann. Rept. 40 (1915), p. 223-239.

Durrell, R. H., 1956, Illinoian boundary in southwestern Ohio and northern Kentucky [abs.]: Geol. Soc. America Bull., v. 67, no. 12, pt. 2, p. 1751.

1961, The Pleistocene geology of the Cincinnati area, Field Trip 3, in Geol. Soc. America Guidebook for Field Trips, Cincinnati Mtg., 1961: New York, Geol. Soc. America, p. 47-57.

1965, Airport roadcuts, in Ray, L. L., Kentucky, in Guidebook for Field Conf. G, Great Lakes-Ohio River valley-Internat. Assoc. Quaternary Research (INQUA), 7th Cong., U.S.A., 1965: Lincoln, Nebr., Nebraska Acad. Sci., p. 62-63.

Fenneman, N. M., 1914, Preglacial Miami and Kentucky rivers [abs. with discussion]: Geol. Soc. America Bull., v. 25, p. 85.

1916, Geology of Cincinnati and vicinity: Ohio Geol. Survey, ser. 4, Bull. 19, 207 p.

1931, Physiography of western United States: New York, McGraw-Hill Book Co., 534 p.

1938, Physiography of eastern United States: New York, McGraw-Hill Book Co., 714 p.

Fidlar, M. M., 1948, Physiography of the lower Wabash Valley [Indiana]: Indiana Div. Geology Bull. 2, $112 \mathrm{p}$.

Fisk, H. N., 1944, Geological investigation of the alluvial valley of the lower Mississippi River: Vicksburg, Miss., Mississippi River Comm., 78 p.

Flint, R. F., 1949, Leaching of carbonates in glacial drift and loess as a basis for age correlation: Jour. Geology, v. 57, no. 3, p. 297-303. 1957, Glacial and Pleistocene geology: New York, John Wiley \& Sons, $553 \mathrm{p}$.

Flint, R. F., and others, 1945, Glacial map of North America: Geol. Soc. America Spec. Paper 60, 2 sheets, 37 p., scale $1: 4,555,000$.

-1959, Glacial map of the United States east of the Rocky Mountains: New York, Geol. Soc. America, 2 sheets, scale $1: 1,750,000$.

Fowke, Gerard, 1898, Preglacial drainage in the vicinity of Cincinnati; its relation to the origin of the modern Ohio River, and its bearing upon the question of the southern limits of the ice sheet: Denison Univ. Sci. Lab. Bull. 11, p. 1-10.

1900, The preglacial drainage of Ohio; introduction: Ohio State 
Acad. Sci. Spec. Paper 3, p. 5-9.

1925. The genesis of the Ohio River: Indiana Acad. Sci. Proc., v. 34 , p. 81-102.

1933, The evolution of the Ohio River: Indianapolis, Ind. Hollenbeck Press, 273 p.

Goldthwait, R. P., Dreimanis, Aleksis, Forsyth, J. L., Karrow, P. F., and White, G. W., 1965, Pleistocene deposits of the Erie Lobe, in Wright, H. E., Jr., and Frey, D. G., eds., The Quaternary of the United States: Princeton, N.J., Princeton Univ. Press, p. 85-97.

Goldthwait, R. P., White, G. W., and Forsyth, J. L., 1961, Glacial map of Ohio: U.S. Geol. Survey Misc. Geol. Inv. Map I-316, scale $1: 1$, 500,000 .

Gooding, A. M.,1957, Pleistocene terraces in the upper Whitewater drainage basin, southeastern Indiana: Earlham Coll. Sci. Bull., no. $2,65 \mathrm{p}$.

1963, Illinoian and Wisconsin glaciations in the Whitewater Basin, southeastern Indiana, and adjacent areas: Jour. Geology, v. 71 , no. 6 , p. $665-682$.

1966, The Kansan glaciation in southeastern Indiana: Ohio Jour. Sci., v. 66 , no. 4 , p. $426-433$.

Gray, H. H., and Powell, R. L., 1965, Geomorphology and groundwater hydrology of the Mitchell Plain and Crawford Upland in southern Indiana: Indiana Geol. Survey Field Conf. Guidebook 11, 26 p.

Guyton, W. F., 1946, Artificial recharge of glacial sand and gravel with filtered river water at Louisville, Kentucky: Econ. Geology, v. 41, no. 6 , p. $644-658$.

Happ, S. C., 1934, Drainage history of southeastern Ohio and adjacent West Virginia: Jour. Geology, v. 42, no. 3, p. 264-284.

Hattin, D. E., Nosow, Edmund, Perkins, R. D., Stumm, E. C., Mound, Michael, and Utgaard, John, 1961, Field excursion to the Falls of the Ohio, Field Trip 9 in Geol. Soc. America Guidebook for Field Trips, Cincinnati mtg., 1961: New York, Geol. Soc. America, p. 295-350.

Hayes, C. W., 1899, Physiography of the Chattanooga district, in Tennessee, Georgia, and Alabama: U.S. Geol. Survey Ann. Rept. 19, pt. 2, p. 1-58.

Hendrickson, B. H., Bushnell, T. M., Ulrich, H. P., and Kunkel, D. R., 1930, Soil Survey, Ohio and Switzerland Counties, Indiana: U.S. Dept. Agriculture, Bur. Chemistry and Soils, Soil Survey Rept., Ser. 1930 , no. 37 , p. 1-60.

Horberg, C. L., 1945, A major buried valley in east-central Illinois and its regional relationships: Jour. Geology, v. 53, no. 5, p. 349-359. 1950, Bedrock topography of Illinois: Illinois State Geol. Survey Bull. 73, $111 \mathrm{p}$.

Indiana Geol. Survey, 1956, Geologic map of Indiana: Indiana Geol. Survey Atlas Mineral Resources Indiana Map 9, scale 1:1,000,000.

Ives, P. C., Levin, Betsy, Oman, C. L., Rubin, Meyer, 1967, U.S. Geological Survey radiocarbon dates [pt.] IX: Radiocarbon, v. 9, p. 505-529.

James, J. F., 1888, An ancient channel of the Ohio River at Cincinnati: Cincinnati Soc. Nat. History Jour., v. 11, p. 96-101.

1891, A brief history of the Ohio River: Popular Sci. Monthly, v. 38 , no. 6 , p. 739-748.

Jillson W. R., 1929, Geologic map of Kentucky: Kentucky Geol. Survey, ser. 6, scale $1: 500,000$.

-1943, An abandoned Pliocene channel of the Kentucky River [in Kentucky]: Frankfort, Ky., Roberts Printing Co., 16 p. [Pliocene River Ser. 1].

-1946, The Easterday abandoned channel of the Ohio River, a study in Pliocene drainage, physiography, and geology: Frankfort, Ky., Roberts Printing Co., 43 p. [Pliocene River Ser. 5].

1947, The Warwick abandoned channel of the Kentucky River, a study in Pliocene drainage, physiography, and geology: Frankfort, Ky., Roberts Printing Co., 38 p. [Pliocene River Ser. 9]. 1949, The piracy of Eagle Creek-A study in Pliocene drainage modification in northern Kentucky: Frankfort, Ky., Roberts Printing Co., $32 \mathrm{p}$.

Johnson, W. A., 1936, Ohio River ${ }^{* * *}$ Letter from The Secretary of War: U.S. 74th Cong., 1st Sess., House Doc. 306, p. 41-49.

Karlstrom, T. N. V., 1961, Pleistocene and post-Pleistocene climatic variations in Alaska and western Canada [abs.]: Pacific Sci. Cong., 10th, Honolulu, 1961, Abs. Symposium Papers, p. 300. 1968, The Quaternary time scale-A current problem of correlation and radiometric dating, in Means of correlation of Quaternary successions-Internat. Assoc. Quaternary Research (INQUA), 7th Cong., U.S.A., 1965, Proc., v. 8: Salt Lake City, Utah, Utah Univ. Press, p. 121-150.

Kentucky Geological Survey, 1954, Geologic map of Kentucky: Lexington, Ky., in coop. with Kentucky Agr. and Indus. Devel. Board, scale $1: 1,000,000$

King, P. B., 1951, The tectonics of middle North America-Middle North America east of the Cordilleran System: Princeton, N.J., Princeton Univ. Press, $203 \mathrm{p}$.

Leighton, M. M., and Ray, L. L., 1965, Glacial deposits of Nebraskan and Kansan age in northern Kentucky: U.S. Geol. Survey Prof. Paper 525-B, p. B126-B131.

Leopold, L. B., and Wolman, M. G., 1957, River channel patterns-braided, meandering, and straight: U.S. Geol. Survey Prof. Paper 282-B, p. 39-85.

Leverett, Frank, 1892, On the significance of the white clays of the Ohio region: Am. Geologist, v. 10, p. 18-24. 1899, The Illinois glacial lobe: U.S. Geol. Survey Mon. 38, 817 p. 1902 , Glacial formations and drainage features of the Erie and Ohio basins: U.S. Geol. Survey Mon. 41, 802 p.

1929, Pleistocene of northern Kentucky: Kentucky Geol. Survey, ser. 6 , v. 31 , p. $1-80$.

Levin, Betsy, Ives, P. C., Oman, C. L., and Rubin, Meyer, 1965, U.S. Geological Survey radiocarbon dates [pt.] VIII: Radiocarbon, v. 7, p. 372-398.

Locke, John, 1845, Geological [a letter to the editors]: Daily Cincinnati Gazette (Ohio), v. 19, no. 5639, Sept. 23, 1845.

Lockett, J. R., 1947, Development of structures in basin areas of northeastern United States: Am. Assoc. Petroleum Geologists Bull., v. 31, no. 3, p. 429-446.

Luft, S. J., 1969, Geologic map of the Independence quadrangle, Kenton and Boone counties, Kentucky: U.S. Geol. Survey Geol. Quad. Map GQ-785.

MacCary, L. M., 1955, Map of the Louisville area, Kentucky, showing contours on the bedrock surface: U.S. Geol. Survey Hydrol. Inv. Atlas HA-5, scale about 1 in. to $1 \mathrm{mi}$.

McFarlan, A. C., 1943, Geology of Kentucky: Lexington, Ky., Univ. Kentucky, $531 \mathrm{p}$.

Malott, C. A., 1922, The physiography of Indiana, in Handbook of Indiana geology: Indiana Dept. Conservation Pub. 21, p. 59-256.

Miller, A. M., 1919, The geology of Kentucky: Kentucky Dept. Geology and Forestry, ser. 5, Bull. 2, $392 \mathrm{p}$. 1925, Geology of Woodford County [Kentucky]: Kentucky Geol. Survey, ser. 6 , v. 21 , p. 119-144.

Moore, R. C., 1936, Stratigraphic evidence bearing on problems of continental tectonics: Geol. Soc. America Bull., v. 47, no. 11, p. 17851808.

Murray, H. H., compiler, 1955, Sedimentation and stratigraphy of the Devonian rocks of southeastern Indiana: Indiana Geol. Survey Field Conf. Guidebook 8, $73 \mathrm{p}$.

Norris, S. E., 1948, The bedrock surface and former drainage systems of Montgomery County, Ohio: Ohio Jour. Sci., v. 48, no. 4, p. 146150.

Norris, S. E., and Spicer, H. C., 1958, Geological and geophysical study of the preglacial Teays Valley in west-central Ohio: U.S. Geol. Survey Water-Supply Paper 1460-E, p. 199-232. 
Norris, S. E., and Spieker, A. M., 1966, Ground-water resources of the Dayton area, Ohio: U.S. Geol. Survey Water-Supply Paper 1808, $167 \mathrm{p}$.

Patton, J. B., Perry, T. G., and Wayne, W. J., 1953, Ordovician stratigraphy and the physiography of part of southeastern Indiana: Indiana Geol. Survey Field Conf. Guidebook 6, 29 p.

Ray, L. L., 1957, Two significant new exposures of Pleistocene deposits along the Ohio River valley in Kentucky: Jour. Geology, v. 65, no. 5 , p. $542-545$.

-1960 , Significance of loess deposits along the Ohio River valley, in Short papers in the geological sciences: U.S. Geol. Survey Prof. Paper 400-B, p. B-211.

- 1963a, Silt-clay ratios of weathering profiles of Peorian Loess along the Ohio Valley: Jour. Geology, v. 71, no. 1, p. 38-47. $1963 \mathrm{~b}$, Quaternary events along the unglaciated lower Ohio River valley, in Short papers in geology and hydrology: U.S. Geol. Survey Prof. Paper 475-B, p. B125-B128; reprinted in Studies on Quaternary 1963-1965, U.S. Geol. Survey, for distribution at the 7th Internat. Cong. Quaternary Research (INQUA), p. 86-89, 1965.

1964, The Charleston, Missouri, alluvial fan, in Geological Survey research 1964: U.S. Geol. Survey Prof. Paper 501-B, p. B130-B134. 1965a, Geomorphology and Quaternary geology of the Owensboro quadrangle, Indiana and Kentucky: U.S. Geol. Survey Prof. Paper 488, $72 \mathrm{p}$.

1965b, Pre-Wisconsin glaciations in Kentucky: Geol. Soc. America Southeastern Sec., Ann. mtg., Nashville, Tenn., Program; reprinted in Abstracts, 7th Internat. Cong. for Quaternary Research (INQUA), p. 387.

-1965c, Kentucky, in Guidebook for Field Conference G, Great Lakes-Ohio River valley-Internat. Assoc. Quaternary Research (INQUA), 7th Cong., U.S.A., 1965: Lincoln, Nebr., Nebraska Acad. Sci., p. 53-63.

1966, Pre-Wisconsin glacial deposits in northern Kentucky, in Geological Survey research 1966: U.S. Geol. Survey Prof. Paper 550-B, p. B91-B94.

1967, An interpretation of profiles of weathering of the Peorian Loess of western Kentucky, in Geological Survey research 1967: U.S. Geol. Survey Prof. Paper 575-D, p.D221-D227.

1969 , Glacial erratics and the problem of glaciation in northeast Kentucky and southeast Ohio-A review and suggestion, in Geological Survey research 1969: U.S. Geol. Survey Prof. Paper 650-D, p. D195-D199.

Ray, L. L., and Karlstrom, T. N. V., 1968, Theoretical concepts in timestratigraphic subdivision of glacial deposits, in Means of correlation of Quaternary successions: Internat. Assoc. Quaternary Research (INQUA), 7th Cong., U.S.A., 1965, Proc., v. 8, p. 115-120.

Rhodehamel, E. C., and Carlston, C. W., 1963, Geologic history of the Teays Valley in West Virginia: Geol. Soc. America Bull., v. 74, no. 3, p. 251-273.

Rich, J. L., 1956, Pre-Illinoian age of upland till in southeastern Indiana, southwestern Ohio, and adjacent parts of Kentucky [abs.]: Geol. Soc. America Bull., v. 67, no. 12, pt. 2, p. 1756.

Richmond, G. M., 1969, Comparison of the Quaternary stratigraphy of the Alps and Rocky Mountains: Internat. Assoc. Quaternary Research (INQUA), 8th Cong., France, 1969, Presidential address: Paris, France (mimeographed).

Rubin, Meyer, and Alexander, Corrinne, 1960, U.S. Geol. Survey radiocarbon dates [pt.] V:Am. Jour. Sci. Radiocarbon Supp., v. \&, p. 129-185.

Russell, R. J., 1940, Quaternary history of Louisiana: Geol. Soc. America Bull., v. 51, no. 8, p. 1199-1233.

1944, Lower Mississippi Valley loess: Geol. Soc. America Bull., v. 55 , no. 1, p. $1-40$.

Schaber, G. G., 1962, The weathered, high-level sands and silts of northern Kenton County, Kentucky: Compass, v. 40, no. 1, p. 27-
38.

Schultz, C. B., Tanner, L. G., Whitmore, F. C., Jr., Ray, L. L., and Crawford, E. C., 1963, Paleontologic investigations at Big Bone Lick State Park, Kentucky-A preliminary report: Science, v. 142 , no. 3596 , p. $1167-1169$.

1967, Big Bone Lick, Kentucky-A pictorial story of the paleontological excavations at this famous fossil locality from 1962 to 1966: Nebraska Univ. State Mus., Mus. Notes 33 (Univ. Nebraska News, v. 46 , no. 22) 12 p.

Shaw, E. W., 1911, Preliminary statement concerning a new system of Quaternary lakes in the Mississippi basin: Jour. Geology, v. 19, no. 6, p. 481-491.

1915, Newly discovered beds of extinct lakes in southern and western Illinois: Illinois State Geol. Survey Bull. 20, p. 139-157.

Siebenthal, C. E., 1901, The Silver Creek hydraulic limestone of southeastern Indiana: Indiana Dept. Geology and Nat. Resources Ann. Rept. 25, p. 331-389.

Speer, P. R., and Gamble, C. R., 1965, Magnitude and frequency of floods in the United States-Pt. 3-A, Ohio River basin except Cumberland and Tennessee River basins: U.S. Geol. Survey Water-Supply Paper 1675, 630 p.

Stout, W. E., 1941, Dolomites and limestones of western Ohio: Ohio Geol. Survey, ser. 4, Bull. 42, 468 p.

Stout, W. E., and Lamb, G. F., 1938, Physiographic features of southeastern Ohio: Ohio Jour. Sci., v. 38, no. 2, p. 49-83.

Stout, W. E., and Schaaf, Downs, 1931, Minford silts of southern Ohio: Geol. Soc. America Bull., v. 42, no. 3, p. 663-672.

Stout, W. E., Ver Steeg, Karl, and Lamb, G. F., 1943, Geology of water in Ohio (a basic report): Ohio Geol. Survey, ser. 4, Bull. 44 [1944], $694 \mathrm{p}$.

Sutton, George, 1877, Glacial or ice deposits in Boone County, Ky., of two distinct and widely distant periods: Am. Assoc. Adv. Sci. Proc., v. 25, p. 225-231; Indiana Geol. Surve Ann. Rept. 8-9-10, p. 108-113 (1879).

Swadley, W C, 1969a, Geologic map of the Union quadrangle, Boone County, Kentucky: U.S. Geol. Survey Geol. Quad. Map GQ-779.

$-1969 \mathrm{~b}$, Geologic map of the Verona quadrangle, north-central Kentucky: U.S. Geol. Survey Geol. Quad. Map GQ-819.

Taylor, A. E., Hodson, Ivan, Conrey, G. W., Craig, William, and Morgan, B. D., 1923, Soil survey, Clermont County, Ohio: U.S. Dept. Agriculture, Bur. Chemistry and Soils, Soil Survey Rept., Ser. 1923 , no. 22 , p. $715-748$.

Theis, C. V., 1922, The geology of Henderson County, Kentucky: Cincinnati Univ., unpub. doctoral dissertation, $215 \mathrm{p}$.

Thornbury, W. D., 1932, Notes on the glacial boundary in southern Indiana: Indiana Acad. Sci. Proc., v. 41, p. 351-354.

1937, Glacial geology of southern and south-central Indiana: Indiana Div. Geology pub., 138 p.

1950, Glacial sluiceways and lacustrine plains of southern Indiana: Indiana Div. Geology Bull. 4, 21 p.

1965, Regional geomorphology of the United States: New York, John Wiley \& Sons, $609 \mathrm{p}$.

Thwaites, F. T., 1946, Outline of glacial geology: Ann Arbor, Mich., Edwards Bros., 129 p.

Tight, W. G., 1903, Drainage modifications in southeastern Ohio and adjacent parts of West Virginia and Kentucky: U.S. Geol. Survey Prof. Paper 13, 111 p.

Trowbridge, A. C., 1966, Glacial drifts in the "Driftless Area" of northeast Iowa: Iowa Geol. Survey Rept. Inv. 2, $28 \mathrm{p}$.

Wanless, H. R., 1939, Pennsylvanian correlations in the eastern Interior and Appalachian coal fields: Geol. Soc. America Spec. Paper 17, $130 \mathrm{p}$.

Warder, R. B., 1872, Geology of Dearborn, Ohio, and Switzerland Counties [Indiana]: Indiana Geol. Survey Ann. Rept. 3-4, p. 387434. 
Wayne, W. J., 1952, Pleistocene evolution of the Ohio and Wabash Valleys [Indiana]: Jour. Geology, v. 60, no. 6, p. 575-585.

-1955, Geomorphology of field conference area, in Murray, H. H., compiler, Sedimentation and stratigraphy of the Devonian rocks of southeastern Indiana: Indiana Geol. Survey Field Conf. Guidebook 8, p. 46-48.

1956, Thickness of drift and bedrock topography of Indiana north of the Wisconsin glacial boundary: Indiana Geol. Survey Prog. Rept. 7, 70 p.

1958, Glacial geology of Indiana: Indiana Geol. Survey Atlas Mineral Resources Indiana Map 10, scale $1: 1,000,000$.

Westgate, L. G., 1930, White clays or upland-flat soils of southern Ohio: Geol. Soc. America Bull., v. 41, no. 2, p. 329-340. (Abs. Geol. Soc. America Bull., v. 41 , no. 1, p. 85. )
Willman, H. B., and Frye, J. C., 1969, High-level glacial outwash in the Driftless Area of northwestern Illinois: Illinois State Geol. Survey Circ. $440,23 \mathrm{p}$.

Wright, G. F., 1890, The glacial boundary in western Pennsylvania, Ohio, Kentucky, Indiana, and Illinois, with an introduction by $\mathrm{T}$. C. Chamberlin: U.S. Geol. Survey Bull. 58, 112 p.

Wright, H. E., Jr., and Frey, D. G., eds., 1965, The Quaternary of the United States-A review volume for the 7th Congress of the International Association for Quaternary Research (INQUA): Princeton, N. J., Princeton Univ. Press, 922 p.

Zumberge, J. H., 1960, Correlation of Wisconsin drifts in Illinois, Indiana, Michigan, and Ohio: Geol. Soc. America Bull., v. 71, no. 8, p. 1177-1188. 


\section{INDEX}

\section{A}

Abandoned valleys, high-level. See Preglacia! high-level valleys.

Kentucky River meander $\ldots \ldots \ldots \ldots \ldots \ldots, 41,48$

Tenys River ............................

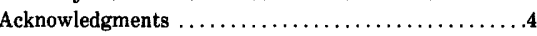

Aftonian interglacial time $\ldots \ldots \ldots \ldots \ldots \ldots \ldots \ldots, 3 s$

Airport sections ....................... 34

Anderson Valley $\ldots \ldots \ldots \ldots \ldots \ldots \ldots \ldots \ldots, 16$

Barbed tributaries................... 17, 18, 52 Barriers to ice movement, Cheviot prong ...........54 Great Miami River valley $\ldots \ldots \ldots \ldots \ldots \ldots, 43,54$ Illinoian .........................4 43, 54

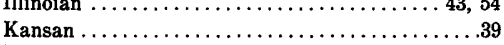
Knobstone-Muldraugh Hill escarpment ...... 35, 37 Licking River valley $\ldots \ldots \ldots \ldots \ldots \ldots \ldots \ldots .43$ Ohio River valley ................... 39, 43 Ohio River valley $\ldots \ldots \ldots \ldots \ldots \ldots \ldots \ldots \ldots \ldots \ldots \ldots \ldots \ldots \ldots \ldots \ldots$
proglacial drainage $\ldots \ldots \ldots \ldots \ldots \ldots \ldots \ldots$

Bedrock, bench, Aftonian ................. 34 bench, Kansan drift $\ldots \ldots \ldots \ldots \ldots \ldots \ldots .34,36$ control of drainage patterns ................10 control of topography $\ldots \ldots \ldots \ldots \ldots \ldots \ldots, 9,58$ formations $\ldots \ldots \ldots \ldots \ldots \ldots \ldots \ldots \ldots \ldots \ldots, 7,9$ islands $\ldots \ldots \ldots \ldots \ldots \ldots \ldots \ldots \ldots \ldots \ldots, \ldots \ldots \ldots$

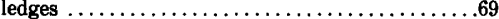
Sangamon erosion ......................57 valleys, buried tributaries ...............69 Ohio River .................4, 43, 49, 65

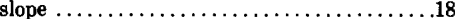
Yarmouth erosion $\ldots \ldots \ldots \ldots \ldots \ldots \ldots \ldots \ldots, 41$

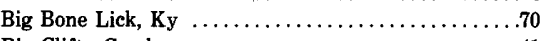
Big Clifty Creek $\ldots \ldots \ldots \ldots \ldots \ldots \ldots \ldots \ldots \ldots \ldots, \ldots \ldots \ldots$ Big Sugar Creek ......................... Bluegrass region $\ldots \ldots \ldots \ldots \ldots \ldots \ldots \ldots \ldots \ldots, 7,9,13$ Bypass channels, Illinoian $\ldots \ldots \ldots \ldots \ldots \ldots \ldots 5,56$ Nebraskan ...........................32

\section{C}

Calcareous concretions $\ldots \ldots \ldots \ldots \ldots \ldots \ldots \ldots \ldots . \ldots \ldots$

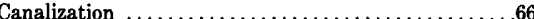
Carbon-14 dates $\ldots \ldots \ldots \ldots \ldots \ldots \ldots \ldots \ldots . .59,64,70$ Carrollton, $\mathrm{Ky}$............................

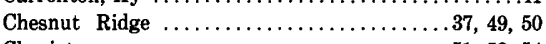
Cheviot prong $\ldots \ldots \ldots \ldots \ldots \ldots \ldots \ldots \ldots \ldots .51,52,54$ Cincinnati arch $\ldots \ldots \ldots \ldots \ldots \ldots \ldots \ldots \ldots \ldots \ldots \ldots$

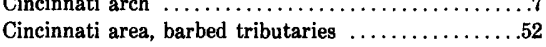
Illinoian drainage changes $\ldots \ldots \ldots \ldots \ldots \ldots .51$ Kansan drainage changes $\ldots \ldots \ldots \ldots \ldots \ldots . . . \ldots$ loop abandonment $\ldots \ldots \ldots \ldots \ldots \ldots \ldots \ldots \ldots, 51,55$ preglacial drainage $\ldots \ldots \ldots \ldots \ldots \ldots \ldots \ldots, 13,53$ pre-Illinoian drainage $\ldots \ldots \ldots \ldots \ldots \ldots \ldots \ldots . \ldots \ldots 1$ Cincinnati River $\ldots \ldots \ldots \ldots \ldots \ldots \ldots \ldots \ldots, 3,30,53$ Cincinnati soil series $\ldots \ldots \ldots \ldots \ldots \ldots \ldots \ldots \ldots .24$ Clermont lobe ........................ 51,56

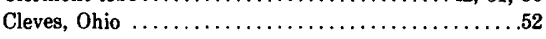
Clifty Falls ......................., 4

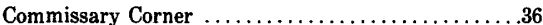

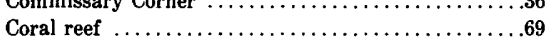
Covington Ridge $\ldots \ldots \ldots \ldots \ldots \ldots \ldots \ldots \ldots \ldots \ldots \ldots$

Craigs Creek ..........................

\section{D}

Dabney section ........................ 25, 33

Dams, McAlpine ..........................69 Markland $\ldots \ldots \ldots \ldots \ldots \ldots \ldots \ldots \ldots \ldots, 18,66$ Meldahl $\ldots \ldots \ldots \ldots \ldots \ldots \ldots \ldots \ldots \ldots \ldots \ldots \ldots \ldots \ldots, 66$

[Italic page numbers indicate major references]

Page

Dearborn upland .... $.9,24,42$ "Deep Stage" erosion .................. 38, 40, 51

Definitions, Bluegrass region $\ldots \ldots \ldots \ldots \ldots \ldots \ldots . .9$ Ohio River valley sectors $\ldots \ldots \ldots \ldots \ldots \ldots \ldots, 3$ physiographic province boundary . . . . . . . . . . . 7

Deflation of valley trains ....................59

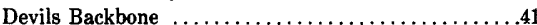

Devonian coral reef $\ldots \ldots \ldots \ldots \ldots, \ldots \ldots \ldots \ldots \ldots, \ldots, \ldots, \ldots \ldots \ldots$ Divides, Anderson Ferry ......................39 between Kentucky and Salt River basins ........32 between Wabash and Ohio River basins .........4 between Whitewater and Ohio River basins .....37 Cheviot prong $\ldots \ldots \ldots \ldots \ldots \ldots \ldots \ldots \ldots, 53$ Cincinnati area $\ldots \ldots \ldots \ldots \ldots \ldots \ldots \ldots \ldots \ldots, 52$ Dayton, Ohio $\ldots \ldots \ldots \ldots \ldots \ldots \ldots \ldots 14,16,19$ Illinoian ........................ 52, 53, 55 Kansan . $\ldots .39$
9,16 Laughery escarpment.................9, 16

Madison, Ind. See Madison divide.

Manchester, Ohio. See Manchester divide.

Miamitown, Ohio .

Mount Hope Church, Ohio ...........53, 55

near Ohio River Mile $488 \ldots \ldots \ldots \ldots \ldots 52,55$

Nebraskan $\ldots \ldots \ldots \ldots \ldots \ldots \ldots \ldots \ldots \ldots, 30,32$

New Baltimore, Ohio ................. 53, 55

New Martinsville, W. Va. .................30

preglacial ........................... 14,19

Silurian formations $\ldots \ldots \ldots \ldots \ldots \ldots \ldots \ldots 14,19$

Walnut Hills prong $\ldots \ldots \ldots \ldots \ldots \ldots \ldots \ldots 52,53$

Drainage, bedrock control $\ldots \ldots \ldots \ldots \ldots \ldots \ldots \ldots .10$

divides. See Divides.

preglacial. See Preglacial drainage.

Drainage modifications, Illinoian

Illinoian, bypass channel s...................5.5

Cincinnati area

Cincinnati loop abandonment ..........51,55

disruptions due to ice tongue $\ldots \ldots \ldots \ldots .55,56$

initial disruptions $\ldots \ldots \ldots \ldots \ldots \ldots \ldots \ldots \ldots . .53$

reversals in flow $\ldots \ldots \ldots \ldots \ldots \ldots \ldots \ldots 55$

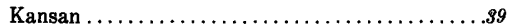

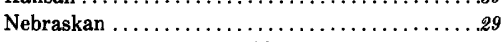

above Manchester divide ............... 30

between Manchester and Madison divides ...\$1

bypass channels $\ldots \ldots \ldots \ldots \ldots \ldots \ldots \ldots . .32$

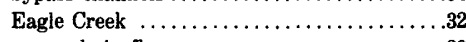

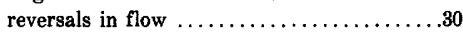

Salt River $\ldots \ldots \ldots \ldots \ldots \ldots \ldots \ldots \ldots, 31,33$

timing with ice advance $\ldots \ldots \ldots \ldots \ldots, 30,31$

west of Madison divide ..................

Drift, Illinoian. See Illinoian drift.

in bedrock Ohio River valley . ...........43, 49

intermixed with outwash

Kansan. See Kansan drift.

Nebraskan. See Nebraskan drift.

pre-Wisconsin, age determinations $\ldots \ldots \ldots \ldots \ldots .37$

Kentucky . . . . . . . . . . . . . . . . . . . .

relation to topography $\ldots \ldots \ldots \ldots \ldots \ldots \ldots . .9$

southeast Indiana .....................38

surficial in southeast Indiana $\ldots \ldots \ldots \ldots 23,24,38$

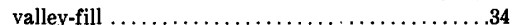

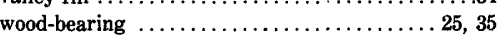

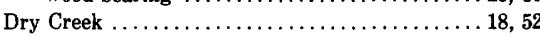

Dunes ...............................60

\section{$\mathbf{E}$}

Eagle Creek $\ldots \ldots \ldots \ldots \ldots \ldots \ldots \ldots \ldots \ldots, 18,32,61$

Easterday channel $\ldots \ldots \ldots \ldots \ldots \ldots \ldots \ldots 17,18,20$

Elijahs Creek ........................... 52

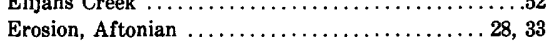

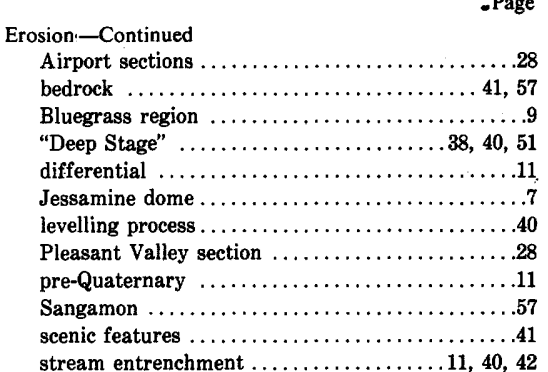

Yarmouth $\ldots \ldots \ldots \ldots \ldots \ldots \ldots \ldots \ldots .28,41,42$

Escarpment, Knobstone-Muldraugh Hill. See Knobstone-Muldraugh Hill escarpment.

Laughery $\ldots \ldots \ldots \ldots \ldots \ldots \ldots \ldots \ldots, 10,16$

Exposures, Batesville, Ind .......................

Big Bone, Ky ..................... 48, 70

Butier Falls, Ind .....................26

drift in Ohio River valley .............. 43, 48

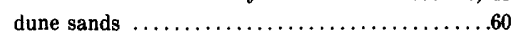

Egypt Bottom ...........................

Flagg Spring Church $\ldots \ldots \ldots \ldots \ldots \ldots \ldots \ldots . \ldots . \ldots . \ldots . \ldots$

Illinoian conglomerate $\ldots \ldots \ldots \ldots \ldots \ldots \ldots \ldots .54$

Illinoian drift $\ldots \ldots \ldots \ldots \ldots \ldots \ldots \ldots \ldots \ldots, 43,48$

Kansan drift ....................... 34, 38

Lookout Heights $\ldots \ldots \ldots \ldots \ldots \ldots \ldots \ldots, 26,34$

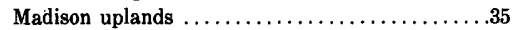

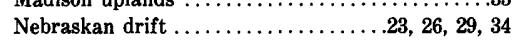

Pleasant Valley Road ....................29

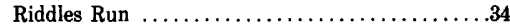

St. Agnes Church ......................26

Twelvemile Church ......................54

Wisconsin (Tazewell) outwash . . ...........60

See also Stratigraphic sections.

\section{F}

Falls of the Ohio $\ldots \ldots \ldots \ldots \ldots \ldots \ldots \ldots \ldots \ldots, \ldots 9$

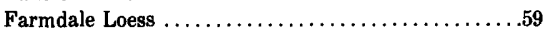

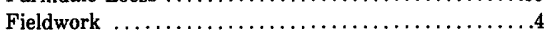

Flagg Spring Creek $\ldots \ldots \ldots \ldots \ldots \ldots \ldots \ldots \ldots \ldots \ldots$

Flood altitudes .............................66

Flood plain of Ohio River .................65

Fluviatile deposits. See High-level fluviatile deposits.

Fluvioglacial deposits, Tazewell ................60 Fossils, Big Bone Lick, Ky ............... 70, 71

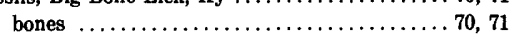

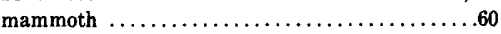
mastadon ............................6.60 Pleasure Ridge Park, Ky ...............61, 64 post-Tazewell $\ldots \ldots \ldots \ldots \ldots \ldots \ldots \ldots \ldots \ldots, 70,71$

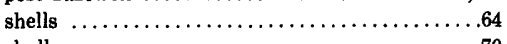

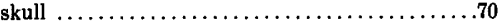
Tazewell ........................59, 60, 64, 70

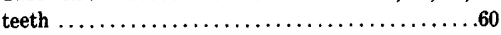

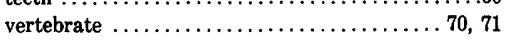
wood $\ldots \ldots \ldots \ldots \ldots \ldots \ldots \ldots \ldots \ldots \ldots, 64,70$

Fourmile Creek ...........................17

\section{G, H}

General Butler State Park ...................41

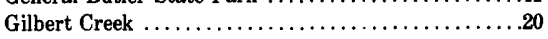
Glaciation, disruption of Teays-Mahomet River system ..21 extent of succeeding ice sheets ..............38

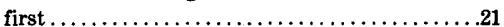
pre-Illinoian, evidence $\ldots \ldots \ldots \ldots \ldots \ldots \ldots 26,29$

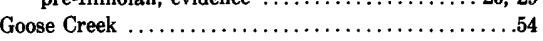




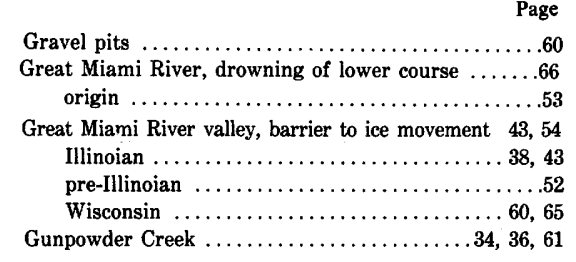

Hamilton River $\ldots \ldots \ldots \ldots \ldots \ldots \ldots \ldots \ldots \ldots 13,14$ Harrison Lobe $\ldots \ldots \ldots \ldots \ldots \ldots \ldots \ldots \ldots \ldots \ldots \ldots, \ldots, \ldots \ldots$

Harrods Creek ......................32, 33, 36

Highland Rim peneplain ....................11

High-level fluviatile deposits, Irvine $\ldots \ldots \ldots \ldots 20,21$

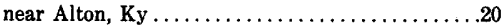
Nebraskan .............................31 preglacial .............................

High-level valleys, Aftonian .....................36 preglacial. See Preglacial high-level valleys.

Hog Trough Creek ...........................41

I

Ice lobes, Clermont $\ldots \ldots \ldots \ldots \ldots \ldots \ldots \ldots, 42,51,56$ Harrison $\ldots \ldots \ldots \ldots \ldots \ldots \ldots \ldots \ldots \ldots \ldots, 43$

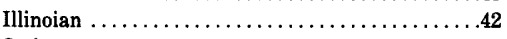
Jackson $\ldots \ldots \ldots \ldots \ldots \ldots \ldots \ldots \ldots \ldots .42,49,50$

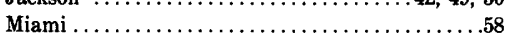

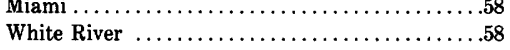

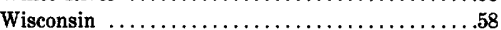

Ice sheets, Labradoran dispersal center ..........29 successive diversion ......................39

Ice tongues, Great Miami River valley $\ldots \ldots \ldots \ldots 43,54$ Illinoian $\ldots \ldots \ldots \ldots \ldots \ldots \ldots \ldots \ldots \ldots .42, \mathbf{4 3}, \mathbf{4 9}$ Licking River valley ....................54 Mill Creek valley $\ldots \ldots \ldots \ldots \ldots \ldots \ldots \ldots \ldots \ldots .58$

Ohio River valley, age determination .........49 conflict with melt-water drainage .........56 distributaries .......................48 downvalley limit $\ldots \ldots \ldots \ldots \ldots \ldots \ldots \ldots . .48$

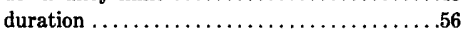
field evidence $\ldots \ldots \ldots \ldots \ldots \ldots \ldots \ldots \ldots \ldots 5$

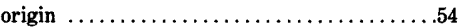
Wisconsin $\ldots \ldots \ldots \ldots \ldots \ldots .58$ Illinoian drift, boundary with Kansan in Indiana $\ldots .49$

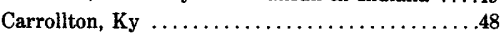
distinguishing features $\ldots \ldots \ldots \ldots \ldots \ldots \ldots .42$ exposures $\ldots \ldots \ldots \ldots \ldots \ldots \ldots \ldots \ldots \ldots, 43,48$ extent $\ldots \ldots \ldots \ldots \ldots \ldots \ldots \ldots \ldots \ldots \ldots \ldots . \ldots \ldots$ in bedrock Ohio River valley $\ldots \ldots \ldots \ldots \ldots, 43,48$ Indiana ................................ Kentucky ............... 42, 54 southern boundary ....................23 topographic expression $\ldots \ldots \ldots \ldots \ldots \ldots \ldots, 43,57$

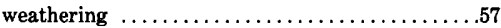

Illinoian ice sheet, configuration. invasion of Cincinnati area .................54 maximum advance $\ldots \ldots \ldots \ldots \ldots \ldots \ldots \ldots, 56$

Interglacial times, Aftonian ..................ss

most important $\ldots \ldots \ldots \ldots \ldots \ldots \ldots \ldots \ldots \ldots 40$

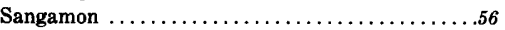

stream degradation versus aggradation $\ldots \ldots \ldots . .41$

Yarmouth ........................... 40

\section{J, K}

Jackson lobe $\ldots \ldots \ldots \ldots \ldots \ldots \ldots \ldots \ldots \ldots, 42,49,50$ Jessamine dome $\ldots \ldots \ldots \ldots \ldots \ldots \ldots \ldots \ldots \ldots, 7,9$

Kame terrace $\ldots \ldots \ldots \ldots \ldots \ldots \ldots \ldots \ldots \ldots, 48,56$ Kansan drift, Airport sections . ...................28 boulders ......................... 24, 35 boundary with Illinoian in Indiana $\ldots \ldots \ldots \ldots . . . .4 y$ differentiation from Nebraskan $\operatorname{drift} \ldots \ldots \ldots \ldots .23$ exposures $\ldots \ldots \ldots \ldots \ldots \ldots \ldots \ldots \ldots \ldots \ldots, 34,38$

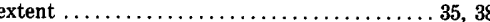
in valleys $\ldots \ldots \ldots \ldots \ldots \ldots \ldots \ldots \ldots \ldots, 34$

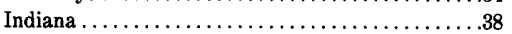
Kentucky uplands $\ldots \ldots \ldots \ldots \ldots \ldots \ldots \ldots \ldots \ldots \ldots \ldots \ldots, 35,36$ on bedrock bench in Ohio valley ......... 34, 36 Pleasant Valley section ................... 28

\section{Kansan drift-Continued}

relation to Nebraskan drift

$\ldots \ldots \ldots \ldots . .38$

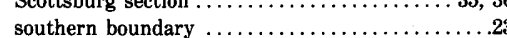

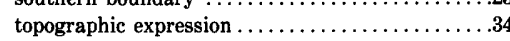

weathering $\ldots \ldots \ldots \ldots \ldots \ldots \ldots \ldots \ldots, 23,40$

west boundary

Kansan ice sheet, maximum advance $\ldots \ldots \ldots \ldots . \ldots \ldots, 39$

Kentucky River, abandoned meanders $\ldots \ldots \ldots \ldots 41,48$ lacustrine terraces $\ldots \ldots \ldots \ldots \ldots \ldots \ldots \ldots \ldots 61$ preglacial $\ldots \ldots \ldots \ldots \ldots \ldots \ldots \ldots \ldots \ldots .40,41,49$ pre-Illinoian history $\ldots \ldots \ldots \ldots \ldots \ldots \ldots \ldots \ldots .49$ present course ......................40 Kentucky uplands, evidence for two preIllinoian glaciations $\ldots \ldots \ldots \ldots \ldots \ldots \ldots .6 \% \ldots$
Illinoian ice extent $\ldots \ldots \ldots \ldots \ldots \ldots \ldots \ldots \ldots \ldots$

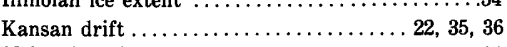
Nebraskan drift $\ldots \ldots \ldots \ldots \ldots \ldots \ldots \ldots \ldots 22,26$ pre-Illinoian time $\ldots \ldots \ldots \ldots \ldots \ldots \ldots \ldots \ldots, 51$ stratigraphic sections ....................28

Knobstone-Muldraugh Hill escarpment ......... 10, 19 barrier to ice movement $\ldots \ldots \ldots \ldots \ldots \ldots \ldots, 37$ overriding by Nebraskan ice ................24 passageways, Kansan ....................40 Muscatatuck-East Fork White River .......40 Nebraskan ..................... 32, 33 preglacial . ...........................19 Salt River gorge $\ldots \ldots \ldots \ldots \ldots \ldots \ldots 32,33,40$

\section{L}

Lacustrine deposits, fossils . Illinoian . . .

Kansan

Nebraskan

Tazewell .

Wisconsin

aughery escarpment

Lexington peneplain pre-Illinoian $\ldots \ldots \ldots \ldots \ldots \ldots \ldots \ldots \ldots \ldots \ldots \ldots \ldots$

Licking River valley, barrier to ice movement . .......43 ice tongue $\ldots \ldots \ldots \ldots \ldots \ldots \ldots \ldots \ldots \ldots, \ldots \ldots \ldots$

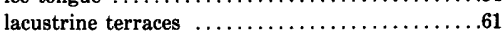
Little Kentucky River $\ldots \ldots \ldots \ldots \ldots \ldots \ldots \ldots \ldots \ldots 6$

Little Miami River ...........................66 Little Sugar Creek . . . . . . . . . . . . . . . . . . .48

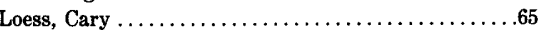
differentiation from Kansan silttil ...........36 Farmdale $\ldots \ldots \ldots \ldots \ldots \ldots \ldots \ldots \ldots \ldots \ldots, 59$ Illinoian $\ldots \ldots \ldots \ldots \ldots \ldots \ldots \ldots \ldots \ldots, 49,57$

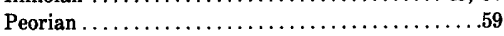
pre-Tazewell $\ldots \ldots \ldots \ldots \ldots \ldots \ldots \ldots \ldots \ldots \ldots . \ldots \ldots$ Long Lick Creek . . . . . . . . . . . . . . . . . . . . . .48 Long Run valley $\ldots \ldots \ldots \ldots \ldots \ldots \ldots \ldots \ldots .64$

M

McCools Creek ...........................17 Madison divide, Kansan .....................39

Laughery escarpment................. 10, 16

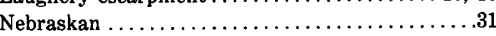
preglacial ........................14, 16, 21 Yarmouth

Manchester divide, Nebraskan ..................30

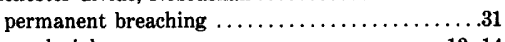
preglacial . ......................... 13, 14

Manchester River $\ldots \ldots \ldots \ldots \ldots \ldots \ldots \ldots \ldots, 34$

Meanders, abandoned. See Preglacial highlevel valleys.

effect on till preservation $\ldots \ldots \ldots \ldots \ldots \ldots \ldots .43$ Kentucky River $\ldots \ldots \ldots \ldots \ldots \ldots \ldots \ldots \ldots, 41,48$

Quaternary ...........................41

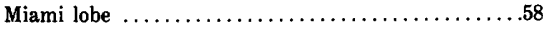

Middle Creek $\ldots \ldots \ldots \ldots \ldots \ldots \ldots \ldots \ldots \ldots . \ldots \ldots, 48$

Middle Creek conglomerate .............. 36, 37

Mill Creek ............................55,58

Millport Knobs ...........................50

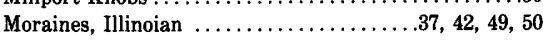
Wisconsin $\ldots \ldots \ldots \ldots \ldots \ldots \ldots \ldots \ldots \ldots \ldots . .58$

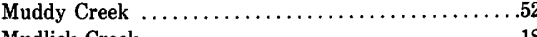

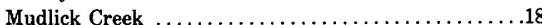

Muldraugh Hill. See Knobstone-Muldraugh Hill escarpment.

Muscatatuck regional slope $\ldots \ldots \ldots \ldots \ldots \ldots \ldots 10,12$

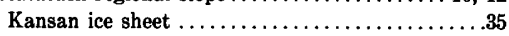
Kansan ice sheet $\ldots \ldots \ldots \ldots \ldots \ldots \ldots \ldots \ldots \ldots \ldots, \ldots \ldots \ldots$
Nebraskan till exposure $\ldots \ldots \ldots \ldots \ldots \ldots \ldots \ldots, \ldots \ldots \ldots$

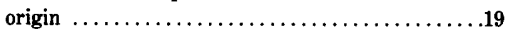
surficial till $\ldots \ldots \ldots \ldots \ldots \ldots \ldots \ldots \ldots \ldots \ldots, 24$

\section{$\mathrm{N}, \mathrm{O}$}

Nashville dome $\ldots \ldots \ldots \ldots \ldots \ldots \ldots \ldots \ldots \ldots, \ldots \ldots \ldots$

Nebraskan drift, differentiation from Kansan drift ..23 exposures $\ldots \ldots \ldots \ldots \ldots \ldots \ldots \ldots \ldots .23,26,29,34$

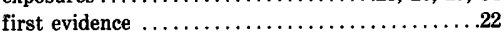
Indiana $\ldots \ldots \ldots \ldots \ldots \ldots \ldots \ldots \ldots \ldots \ldots, 23$ Kentucky uplands .................. 22, 26 Pleasant Valley section ................ 28,33 relation to Kansan drift . . . . . . . . . . . . . 38 Scottsburg section ................... 35, 36 southeast Indiana uplands $\ldots \ldots \ldots \ldots \ldots \ldots \ldots . .35$ southern boundary $\ldots \ldots \ldots \ldots \ldots \ldots \ldots \ldots .22$ stratigraphic sections ................. 24,36

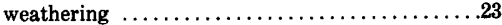

Nebraskan ice sheet, maximum advance ......29, 32 Norman upland $\ldots \ldots \ldots \ldots \ldots \ldots \ldots \ldots \ldots \ldots \ldots . .10$ North Bend-Cleves passageway .............. 52, 55

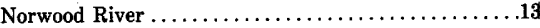

Norwood trough $\ldots \ldots \ldots \ldots \ldots \ldots \ldots \ldots \ldots, 13,55$

Osgood section $\ldots \ldots \ldots \ldots \ldots \ldots \ldots \ldots \ldots \ldots \ldots, 25,39$

Outwash, Cary . . . . . . . . . . . . . . . . . . . . . .65

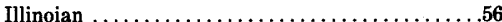
intermixed with drift $\ldots \ldots \ldots \ldots \ldots \ldots \ldots \ldots .48$ Kansan ...................................

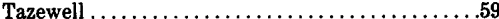
Outwash plain, Kansan ....................27

\section{$\mathbf{P}$}

Paint Creek .....................18

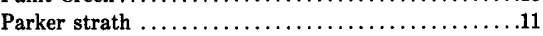

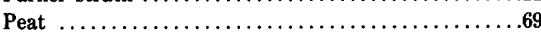

Peneplains ..................................

Peorian Loess ................................59

Phillips Branch $. \ldots \ldots \ldots \ldots \ldots \ldots \ldots \ldots \ldots \ldots \ldots, 36$

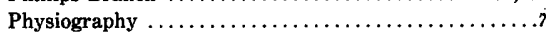

Pleasant Valley section $\ldots \ldots \ldots \ldots \ldots \ldots \ldots \ldots, 28,33$

Pleasure Ridge Park, Ky . . . . . . . .

Preglacial drainage..$\ldots \ldots \ldots \ldots \ldots \ldots \ldots \ldots \ldots \ldots \ldots$

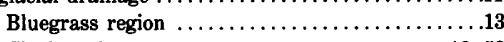

Cincinnati area $\ldots \ldots \ldots \ldots \ldots \ldots \ldots \ldots, 5,53$

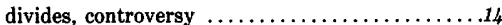
Dayton $\ldots \ldots \ldots \ldots \ldots \ldots \ldots \ldots \ldots 14,16,19$ Madison ...................... 14, 21 Manchester ..................... 13, 14 glacial modification ....................29

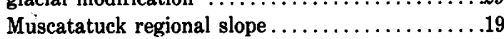
reversed flows $\ldots \ldots \ldots \ldots \ldots \ldots \ldots \ldots \ldots \ldots \ldots \ldots, 18,18$ Salt River system $\ldots \ldots \ldots \ldots \ldots \ldots \ldots \ldots \ldots . .19$ symmetry of basins .....................19 Teays-Mahomet River system $\ldots \ldots \ldots \ldots \ldots 13,21$

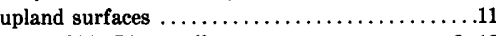
upper Ohio River valley $\ldots \ldots \ldots \ldots \ldots \ldots, 3,13$ Whitewater-Anderson valley $\ldots \ldots \ldots \ldots \ldots \ldots .16$

Preglacial high-level valleys, Alton channel ........20 between Gunpowder and Woolper Creeks ......36 Easterday channel $\ldots \ldots \ldots \ldots \ldots \ldots \ldots \ldots, 18,20$ Great Miami River .....................13 Kentucky River ................... 17, 20, 41 Kentucky uplands ......................... Manchester River .......................13 near Dayton, Ohio $\ldots \ldots \ldots \ldots \ldots \ldots \ldots \ldots \ldots 19$ Ohio River ........................., 17 Wildcat meander ........................20

Preglacial streams, Anderson Valley $\ldots \ldots \ldots \ldots \ldots 15,16$ capture .......................... 15, 20 Cincinnati River ................... 30, 53 East Fork of White River .................19 Hamilton River $\ldots \ldots \ldots \ldots \ldots \ldots \ldots \ldots \ldots \ldots \ldots \ldots \ldots \ldots \ldots \ldots \ldots \ldots \ldots \ldots, 14$

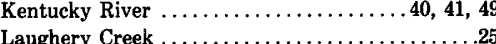




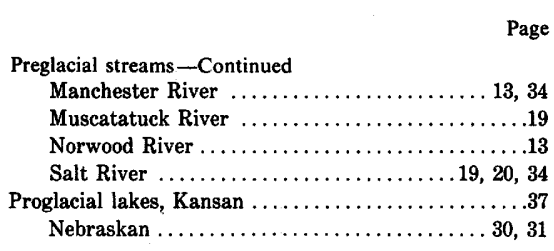

\section{$\mathrm{R}$}

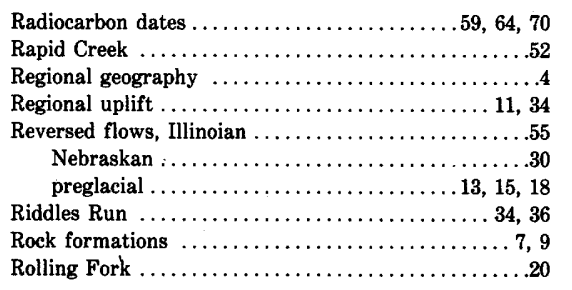

$\mathbf{S}$

Salt River, gorge $\ldots \ldots \ldots \ldots \ldots \ldots \ldots \ldots \ldots .32,33,40$

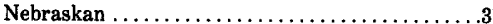

preglacial $\ldots \ldots \ldots \ldots \ldots \ldots \ldots \ldots \ldots \ldots 19,20,34$

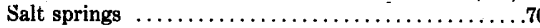

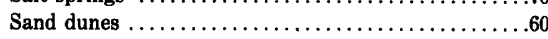

Sangamon interglacial time $\ldots \ldots \ldots \ldots \ldots \ldots \ldots . .56$

Scenic features, origin $\ldots \ldots \ldots \ldots \ldots \ldots \ldots \ldots \ldots . \ldots \ldots$

Scottsburg lowland $\ldots \ldots \ldots \ldots \ldots \ldots \ldots \ldots \ldots 10,19,69$

Scottsburg section $\ldots \ldots \ldots \ldots \ldots \ldots \ldots \ldots \ldots \ldots, 35,36$

Silttil, Aftonian $\ldots \ldots \ldots \ldots \ldots \ldots \ldots \ldots \ldots \ldots \ldots, \ldots$

Soil, Cincinnati series $\ldots \ldots \ldots \ldots \ldots \ldots \ldots \ldots \ldots \ldots 2$ white deoxidized $\ldots \ldots \ldots \ldots \ldots \ldots \ldots \ldots \ldots \ldots, \ldots \ldots \ldots 7$

Split Rock conglomerate $\ldots \ldots \ldots \ldots \ldots \ldots . . ., 48,54,56$ Steele Bottom .............................48

Stephens Creek ..........................18

Stratigraphic sections, Airport . . . . . . . . . 26, 34 Dabney $\ldots \ldots \ldots \ldots \ldots \ldots \ldots \ldots \ldots \ldots, 25,33$

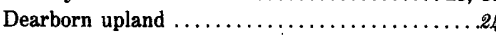
Kentucky uplands .......................28

Muscatatuck State School . . . . . . . . . . . 24, 35

Osgood ............................ 25, 33

Pleasant Valley $\ldots \ldots \ldots \ldots \ldots \ldots \ldots \ldots \ldots 28,33$

Scott County Stone Co. quarry .......... 25, 35

Scottsburg ....................... 35, 36

Spillway $\ldots \ldots \ldots \ldots \ldots \ldots \ldots \ldots \ldots \ldots \ldots 24,35$ See also Exposures.

Stream aggradation .................... 58,69

Stream capture, above Manchester divide

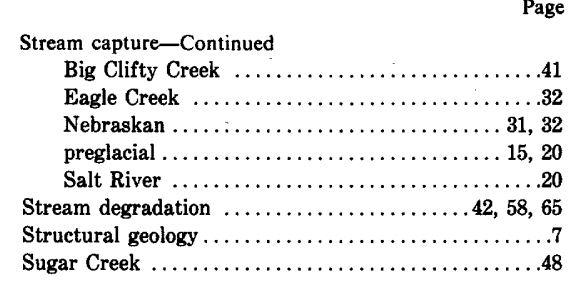

\section{$\mathrm{T}$}

Tampico Ridge $\ldots \ldots \ldots \ldots \ldots \ldots \ldots \ldots \ldots \ldots, 37,50$ Taylor Creek.

37,50

Teays-Mahomet River system .............13, 21, 30

Terraces, Cary ......................64, 66 comparison of Tazewell and Cary slopes .......64 correlation with ice advances ................58 economic value $\ldots \ldots \ldots \ldots \ldots \ldots \ldots \ldots \ldots, 60$

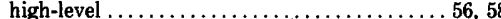

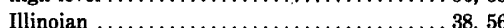

kame $\ldots \ldots \ldots \ldots \ldots \ldots \ldots \ldots \ldots \ldots \ldots \ldots \ldots \ldots, \ldots \ldots \ldots, 58,56$

lacustrine deposits $\ldots \ldots \ldots \ldots \ldots \ldots \ldots 6,70$

low-level .........................64, 70,7

post-Tazewell $\ldots \ldots \ldots \ldots \ldots \ldots \ldots \ldots \ldots \ldots, 64,70,71$

slope of surface $\ldots \ldots \ldots \ldots \ldots \ldots \ldots \ldots \ldots \ldots, 6,64$

Tazewell ........................ $58,70,71$

Whitewater River basin $\ldots \ldots \ldots \ldots \ldots \ldots \ldots \ldots .38$

Wisconsin $\ldots \ldots \ldots \ldots \ldots . . .68$

Till. See Drift.

Topography, bedrock control $\ldots \ldots \ldots \ldots \ldots \ldots ., 23$

Bluegrass region $\ldots \ldots \ldots \ldots \ldots \ldots \ldots \ldots \ldots$

effect on ice advance $\ldots \ldots \ldots \ldots \ldots \ldots \ldots \ldots \ldots \ldots \ldots \ldots \ldots \ldots, 49$

effect on ice advance $\ldots \ldots \ldots \ldots \ldots \ldots \ldots \ldots ., 45,42$
glacial control $\ldots \ldots \ldots \ldots \ldots \ldots \ldots \ldots \ldots, 5, \ldots \ldots \ldots$

Illinoian drift $\ldots \ldots \ldots \ldots \ldots \ldots \ldots \ldots \ldots \ldots 4,57$

Kansan drift $\ldots \ldots \ldots \ldots \ldots \ldots \ldots \ldots \ldots \ldots \ldots, \ldots \ldots$

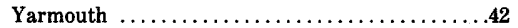

Tributaries, barbed $\ldots \ldots \ldots \ldots \ldots \ldots \ldots \ldots \ldots, 17,52$

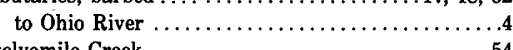

Twelvemile Creek $\ldots \ldots \ldots \ldots \ldots \ldots \ldots \ldots \ldots \ldots \ldots \ldots$

\section{$\mathrm{U}, \mathrm{V}$}

Underfit streams $\ldots \ldots \ldots \ldots \ldots \ldots \ldots \ldots \ldots \ldots, 53,55$ Uplands, Aftonian dissection ................. 33,34

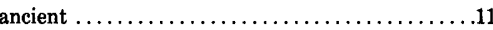
Bluegrass region $\ldots \ldots \ldots \ldots \ldots \ldots, \ldots \ldots \ldots, \ldots$ Cheviot prong . . . . . . . . . . . . . . . . . . . . . 51 Dearborn ....................... 24, 42 Lexington peneplain $\ldots \ldots \ldots \ldots \ldots \ldots \ldots \ldots 1,20$

Norman ..............................10

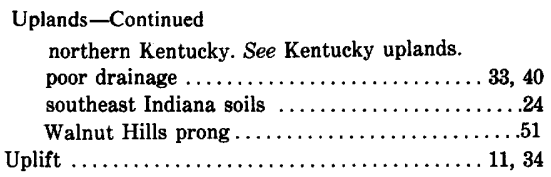

Valley trains, correlative lacustrine terraces .......61

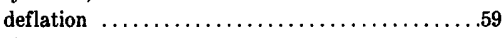
Illinoian $\ldots \ldots \ldots \ldots \ldots \ldots \ldots \ldots \ldots \ldots \ldots \ldots . .57$

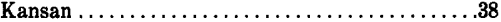
pre-Tazewell $\ldots \ldots \ldots \ldots \ldots \ldots \ldots \ldots \ldots \ldots . \ldots \ldots 59$

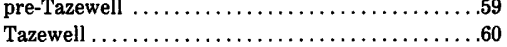
Wisconsin $\ldots \ldots \ldots \ldots \ldots \ldots \ldots \ldots \ldots . .58$

\section{W, Y}

Wabash River ...........................56

Walnut Hills prong $\ldots \ldots \ldots \ldots \ldots \ldots \ldots \ldots \ldots, 51,52$

Waterfalls ...............................41

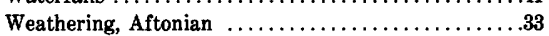
depth of leaching as age indicator $\ldots \ldots \ldots, 23,50$ effect of good drainage $\ldots \ldots \ldots \ldots \ldots \ldots \ldots \ldots .34$ effect of poor drainage $\ldots \ldots \ldots \ldots \ldots \ldots \ldots . .57$

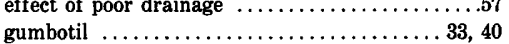
Illinoian drift $\ldots \ldots \ldots \ldots \ldots \ldots \ldots \ldots \ldots \ldots \ldots \ldots$ Kansan drift $\ldots \ldots \ldots \ldots \ldots \ldots \ldots \ldots \ldots \ldots, 23,40$ Nebraskan drift ........................23 post-Tazewell deposits $\ldots \ldots \ldots \ldots \ldots \ldots \ldots \ldots \ldots 64$ pre-Illinoian till $\ldots \ldots \ldots \ldots \ldots \ldots \ldots \ldots \ldots \ldots .24$

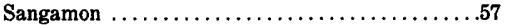
Tazewell deposits $\ldots \ldots \ldots \ldots \ldots \ldots \ldots \ldots \ldots .60$ white deoxidized surficial layer ..............57 Yarmouth ............................40

White River lobe ...........................58

Whites Run ............................. 17

Whitewater River ...................... 15, 16, 54 Whitewater River basin, age of drift .............38

Willow Branch $\ldots \ldots \ldots \ldots \ldots \ldots \ldots \ldots \ldots \ldots \ldots, \ldots \ldots \ldots$

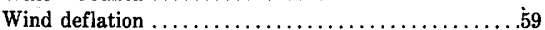

Wisconsin drift, distinguishing features .............58 relation to topography $\ldots \ldots \ldots \ldots \ldots \ldots \ldots \ldots . . . \ldots$ southern boundary $\ldots \ldots \ldots \ldots \ldots \ldots \ldots \ldots \ldots 23$

Wisconsin ice sheet, Cary advance .............65 earliest advance $\ldots \ldots \ldots \ldots \ldots \ldots \ldots \ldots \ldots 5$

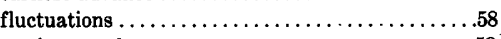
maximum advance $\ldots \ldots \ldots \ldots \ldots \ldots \ldots \ldots \ldots .58$ post-Cary history $\ldots \ldots \ldots \ldots \ldots \ldots \ldots \ldots \ldots 6$ pre-Tazewell history . . . . . . . . . . . . . . ...59 Woolper Creek $\ldots \ldots \ldots \ldots \ldots \ldots \ldots \ldots \ldots \ldots \ldots \ldots \ldots \ldots, 48,56$

Yarmouth interglacial time ................38, 40 


